\title{
The Patterns of spending time among Ayyubid Kings in Bilad Al-Sham and Al-Jazeera (589_658 A.H/ 1193_1259 A.D)
}

\author{
Ako B. Muhammad
}

Muhsin M. Muhammad ${ }^{2}$

Received: Feb23, 2018 Reviewed: Mar11, 2018Accepted: Mar19, 2018

\begin{abstract}

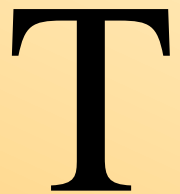

his research is an attempt to illustrate general image of the pattern of spending time among the Ayyubid Kings in Bilad Al-Sham and Al-Jazeera (589_658A.H/ 1193_1259 A.D). In the present paper, the light is shed on their private, secret and formal lives, away from political and military lives by examining how they spent their holidays and leisure times. All this information is supported by a bunch of resurces in which some of them were primary that have been obtained from their period.Although Ayyubid Kings were fighting and struggling in civil war and they were in continuous war against crucifiers; and other who headed towards their region, these were not barriers to spend their normal lives and they brought leisure to their lives. However, some of them spent their lives in various patterns; for instance, doing some physical and ethical activities such as hunting, riding horses, playing Polo (suljan), target shooting, and other mental or intellectual gammes (chess and backgammon). In addition, they spent a lot of money in their mansion for relaxation and happiness, such as participating in philosophical and intellectual meetings. Moreover, they were also listening to songs and music and dedicating a special time for wine drinking. Besides those, they had many particular trips, picnics and vacations to stunning and wonderful places to have some fun.
\end{abstract}

Keywords:Ayyubid Kings, Bilad Al- Sham, Al- Jazeera, Pattern, Leisure time, Crucifier

\section{Recommended citation:}

Muhammad A. B. \& Muhammad M. M. (2018). The Patterns of spending time among Ayyubid Kings in Bilad Al- Sham and Al- Jazeera (589_658 A.H/ 1193_1259 A.D). International Journal of Kurdish Studies 4 (2), 416-453. doi: 10.21600/ ijoks.454465

\footnotetext{
${ }^{1}$ Prof. Dr., University of Salahaddin, Collage of Arts, Erbil, KRG, Iraq, E-mail: ako.muhamad1@su.edu.krd

${ }^{2}$ Asst. Lecturer, University of Salahaddin, Collage of Arts, Erbil, KRG, Iraq,

E-mail: muhsin.muhammad@su.edu.krd
} 


\section{شديّوازهكانى كات به سهر بردنى مره ليكه كانى كأيوبى له ناوجه كانى شام وجهمزيره}

\section{(j1259_1193 / ك658_589)}

\section{ب.د. اكوّ برهان مجحد م.ى. محسن مامل مجحد}

\section{زانكوّى سهلاحهددين/ كوّليّزى ئهدهبيات}

\section{يوختـــــــ}

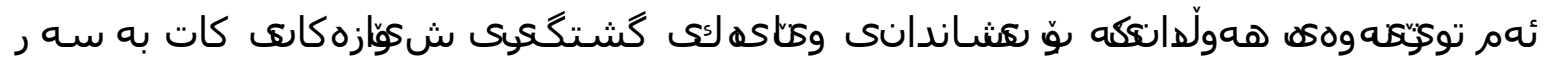

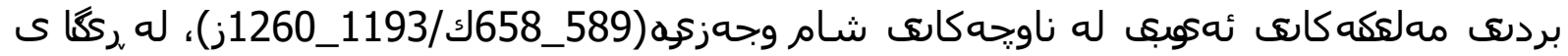

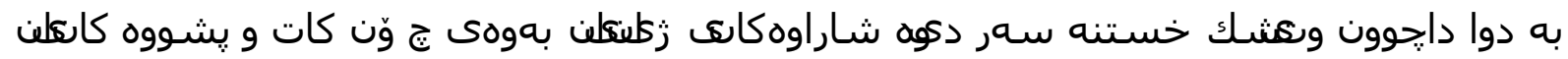

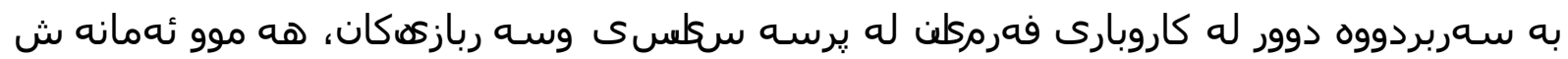

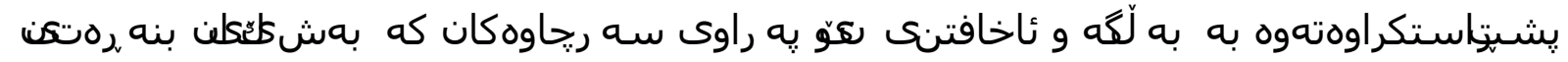

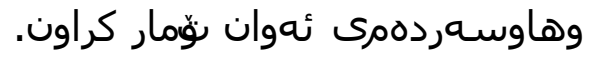

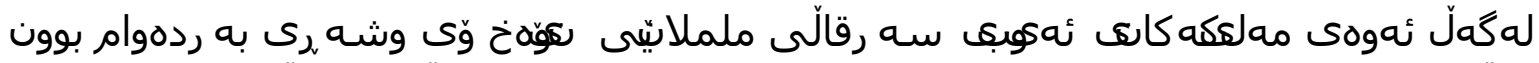

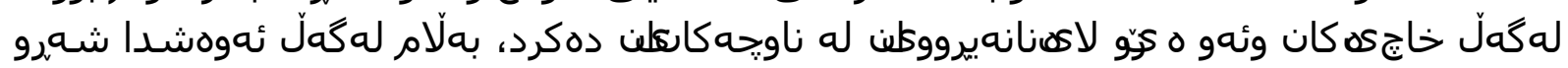

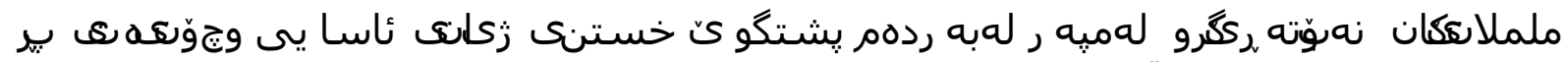

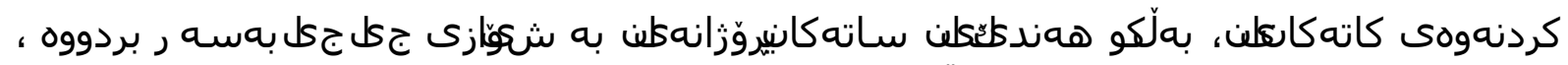

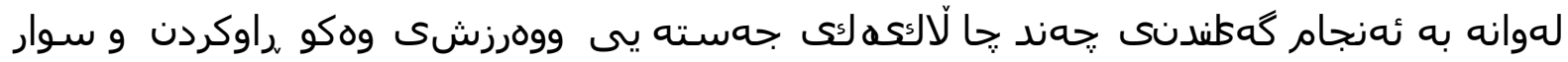

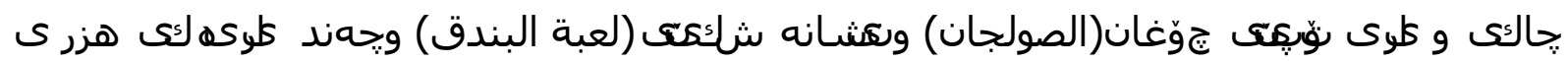

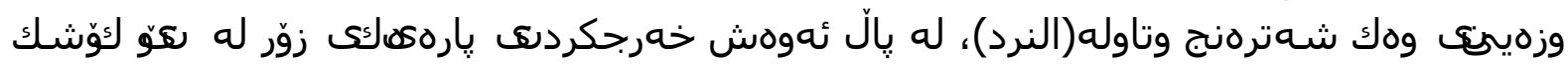

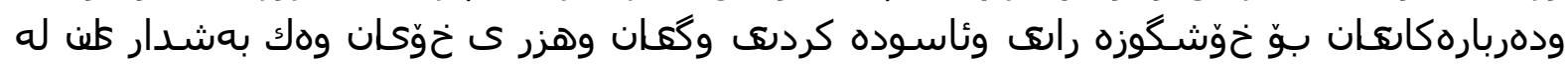

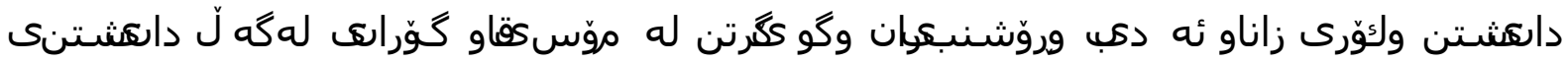

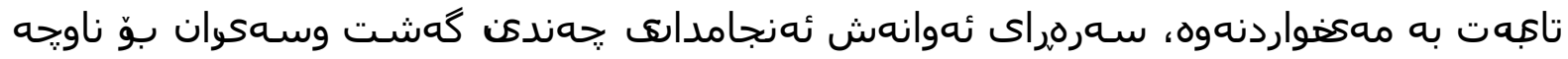

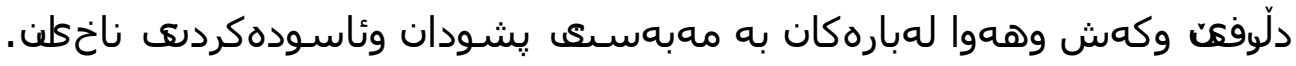

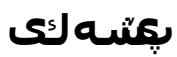

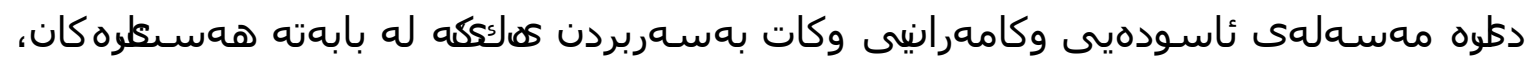

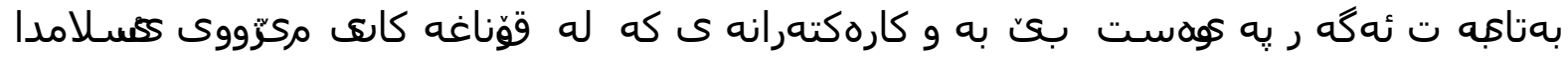

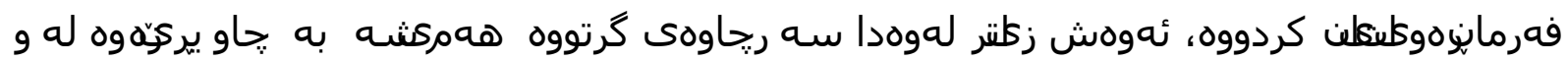

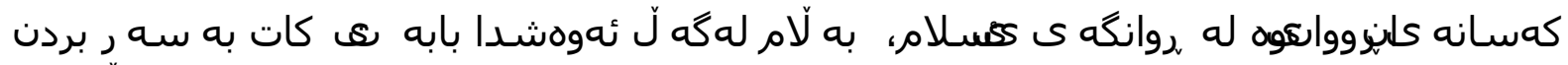

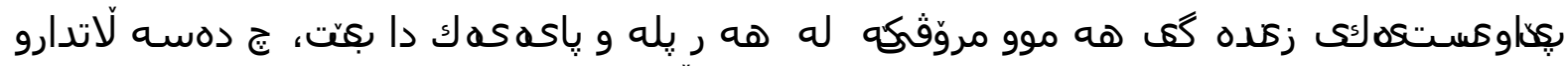

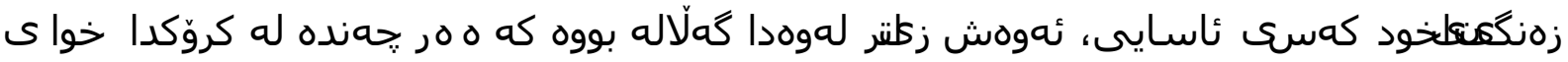

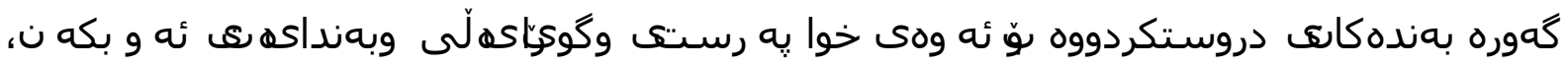

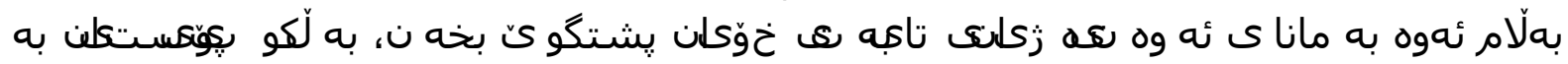

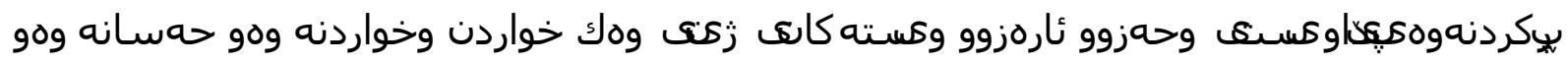




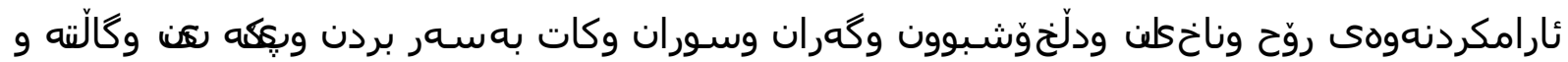

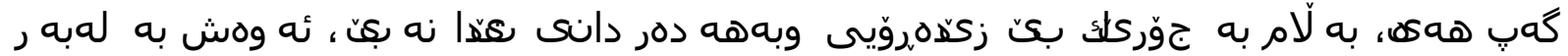

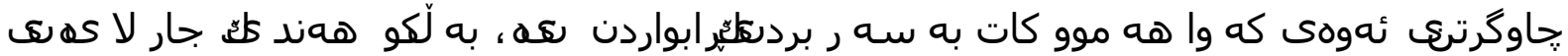

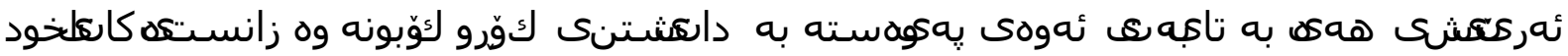

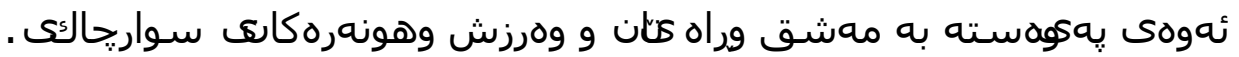

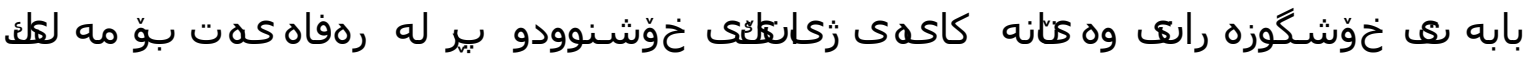

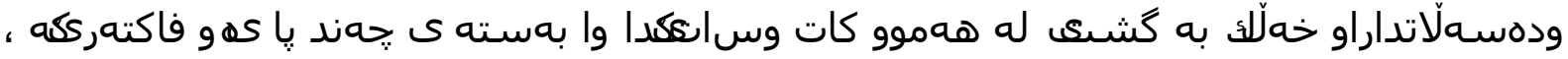

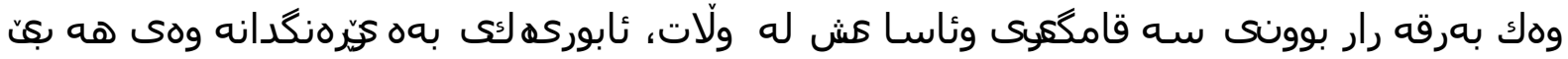

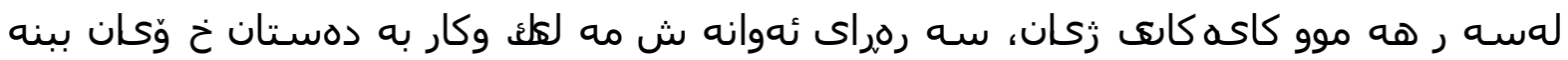

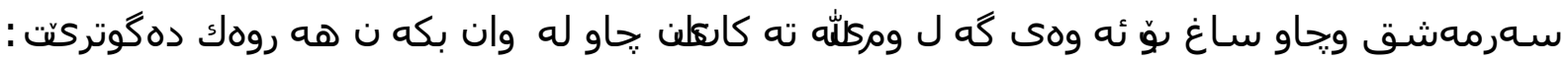

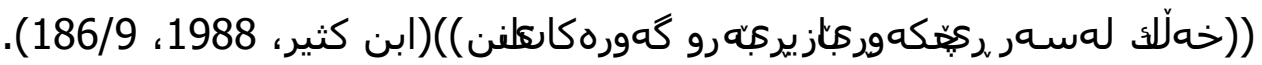

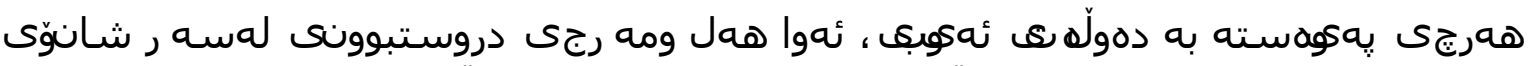

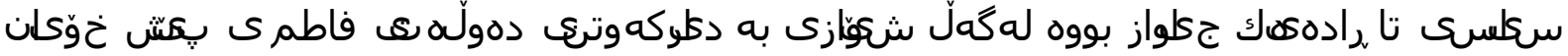

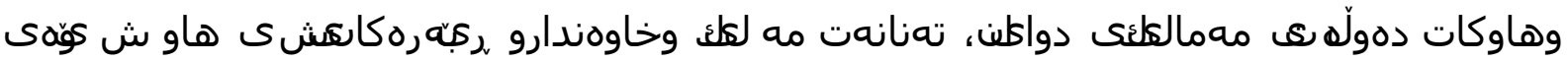

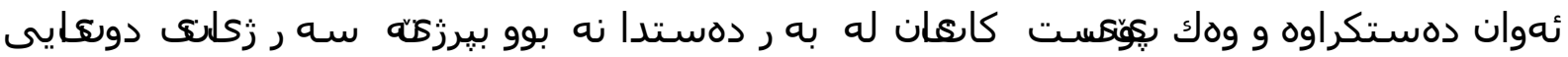

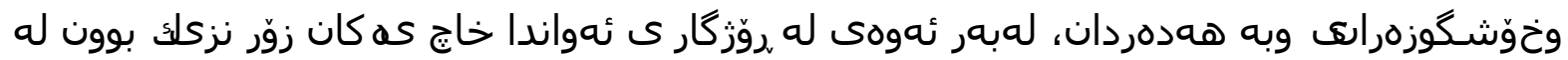

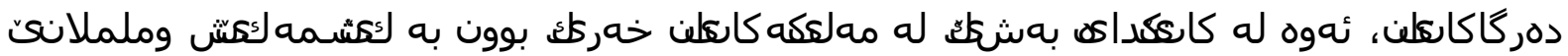

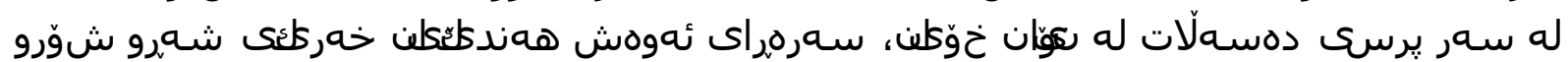

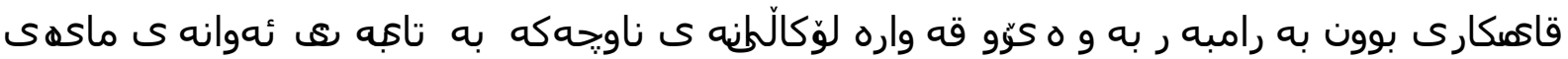

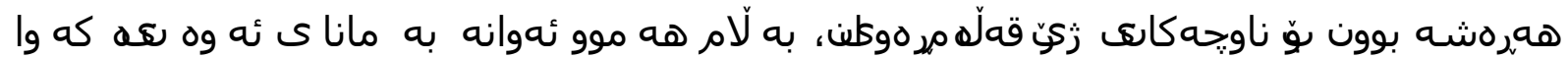

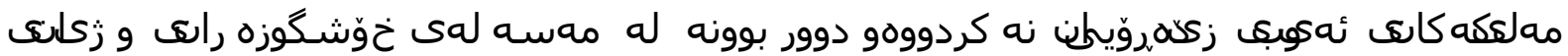

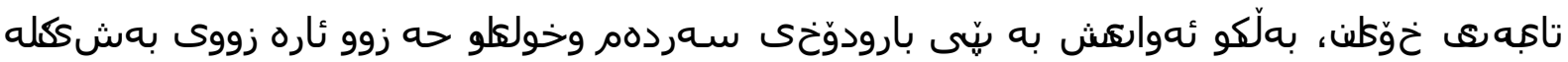

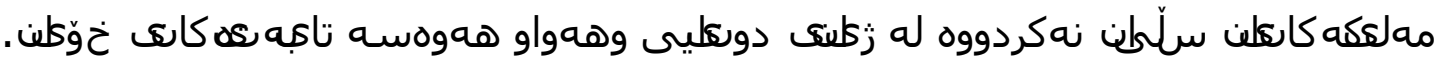

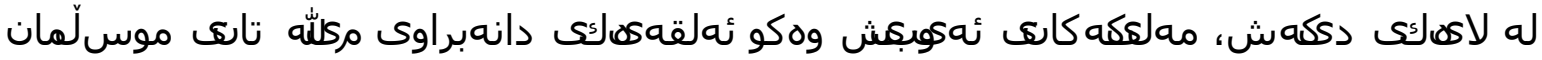

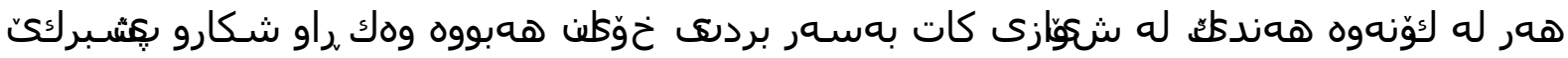

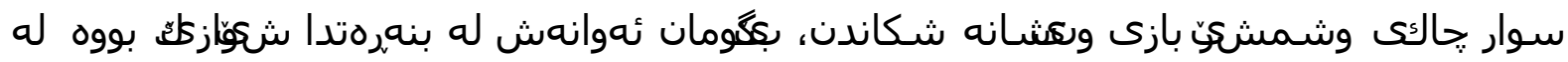

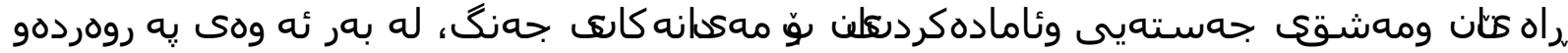

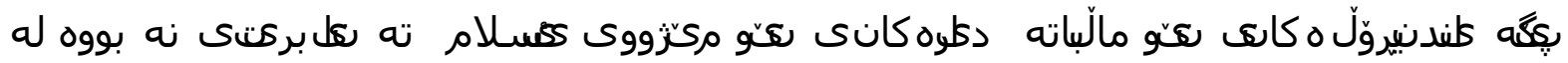

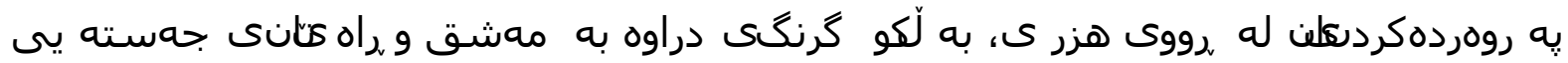

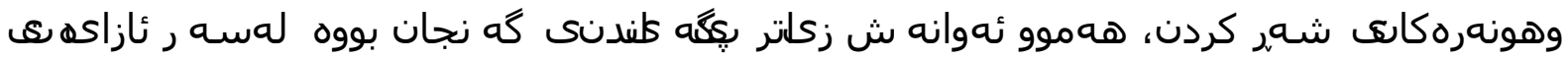

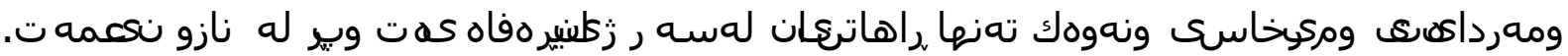

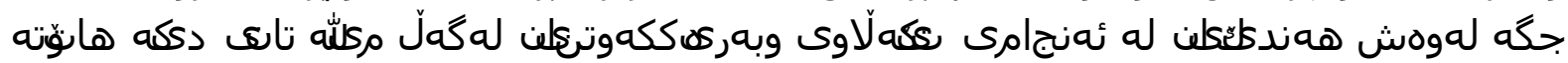

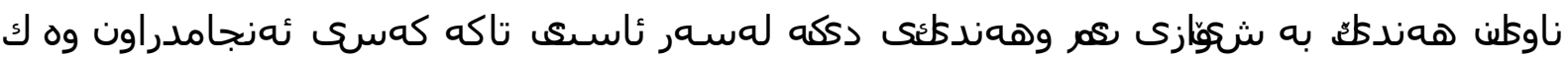

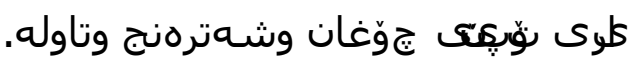

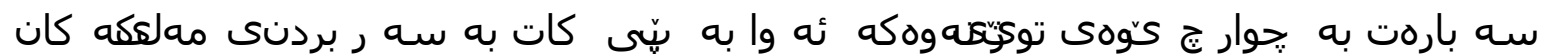

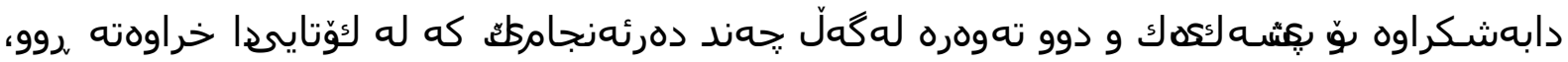

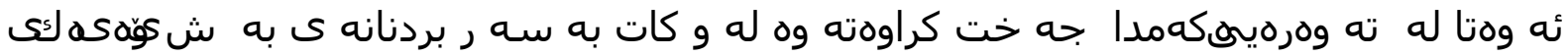

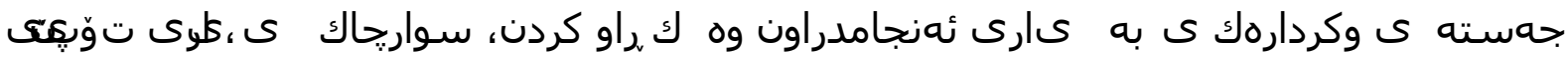

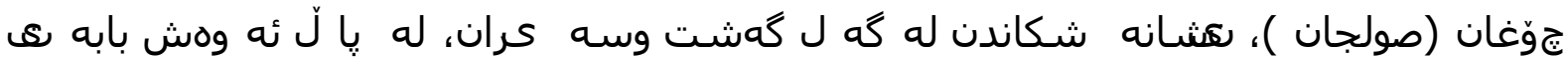




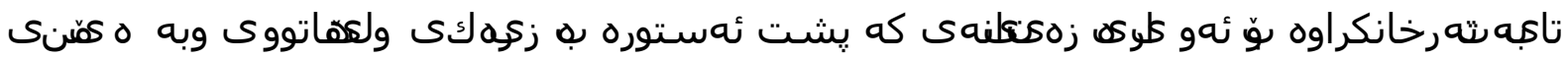

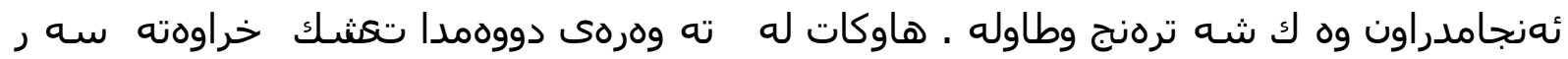

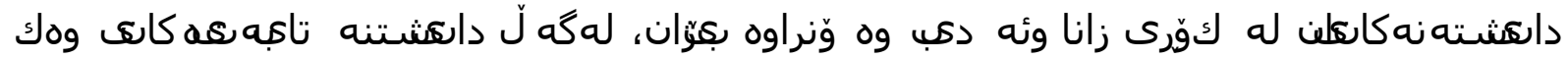

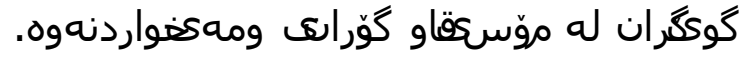

\section{كه كه م/ كات به سه ر بردنه كان به ش كڤّازى جهسته يى وكردارهك ى وكارى نونجامدراون ون ون}

\section{1}

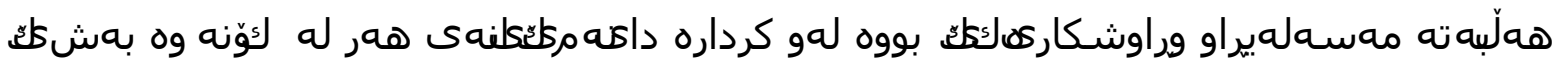

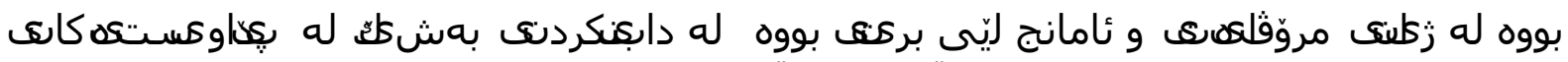

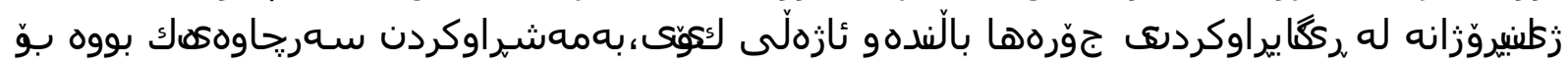

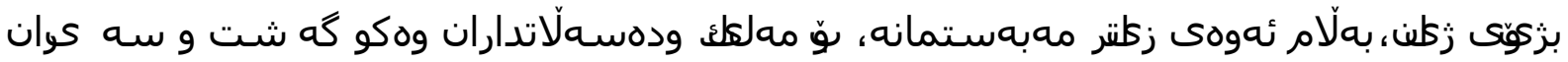

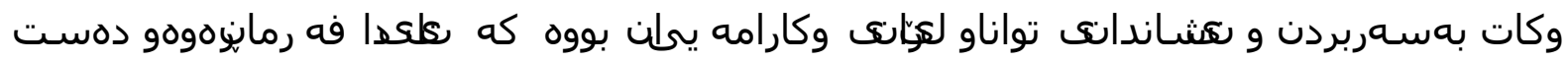

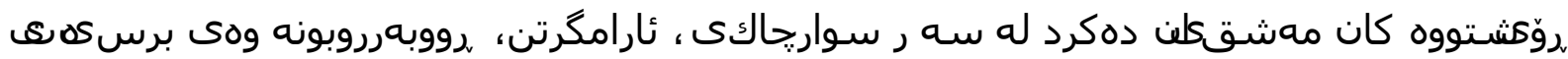

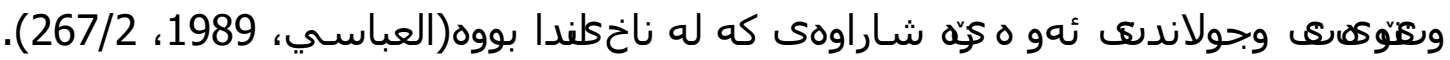

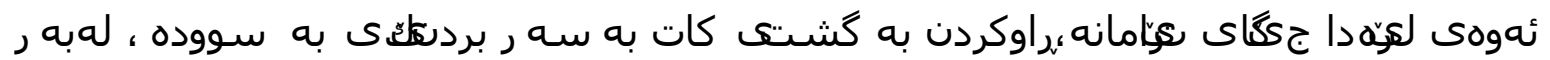

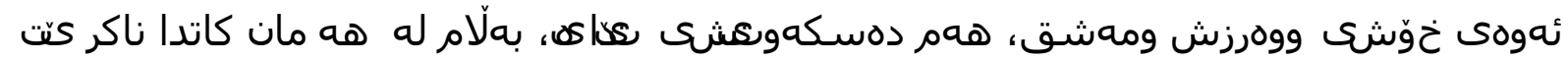

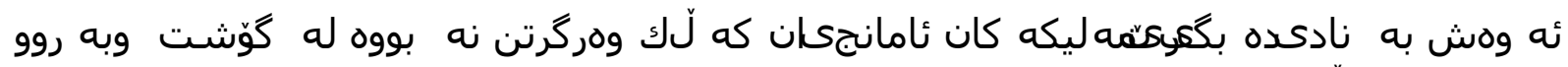

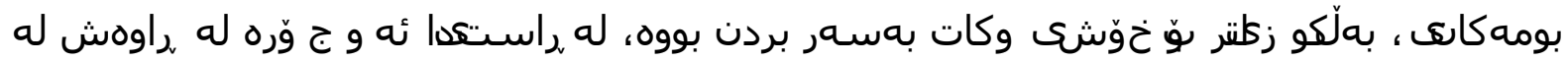

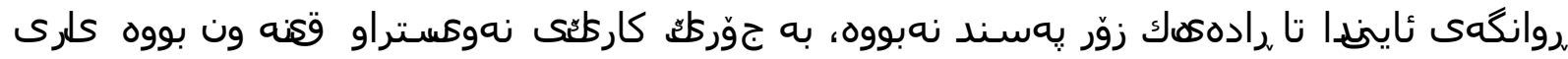

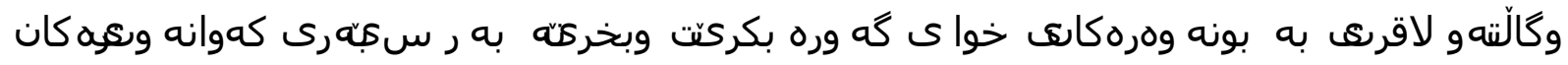

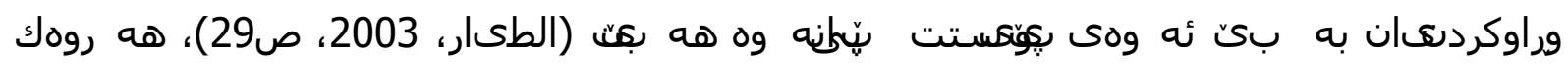

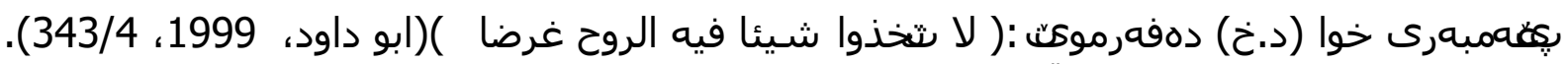

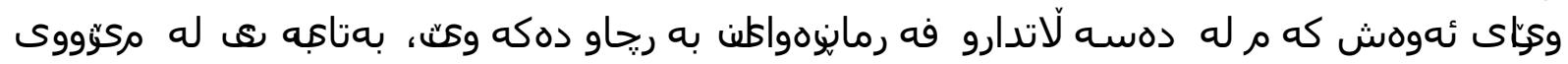

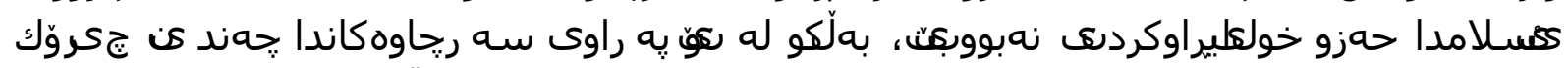

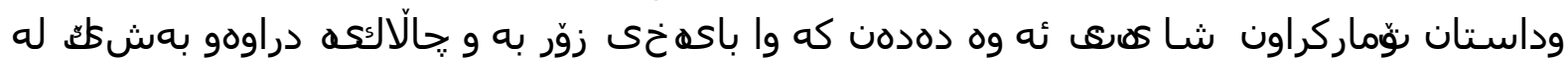

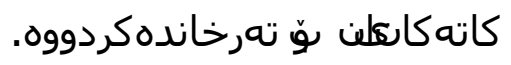

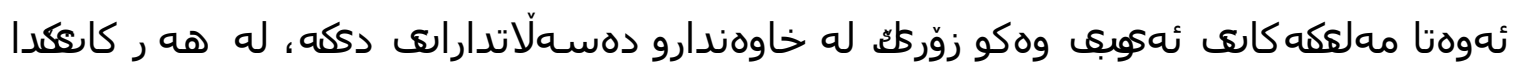

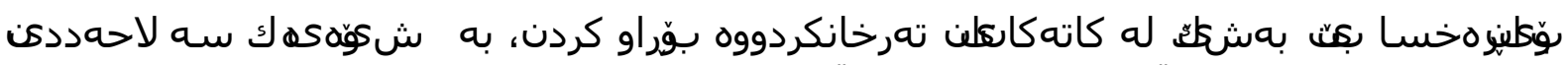

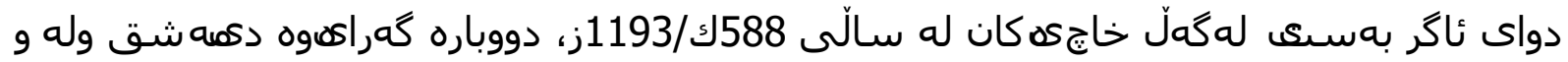

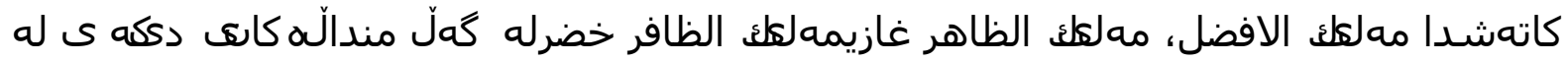

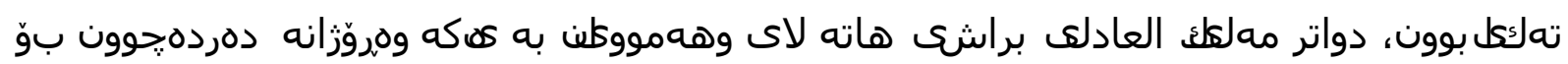

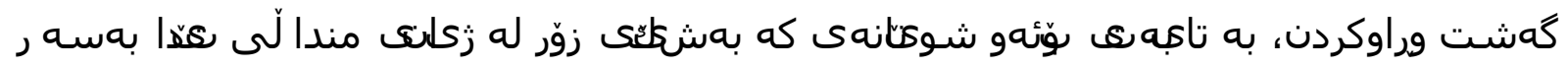

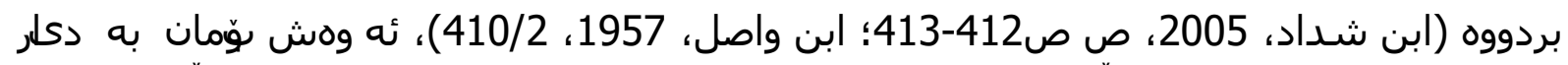

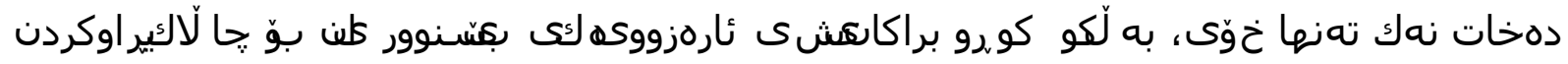

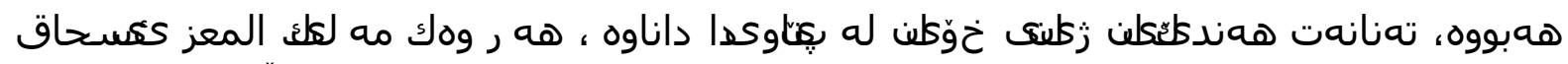

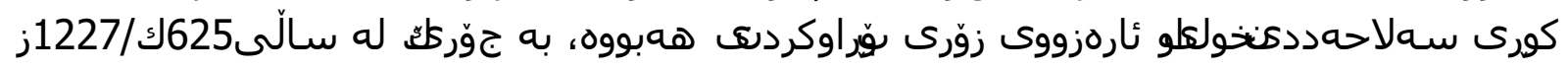




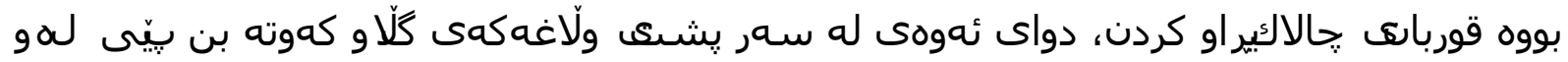

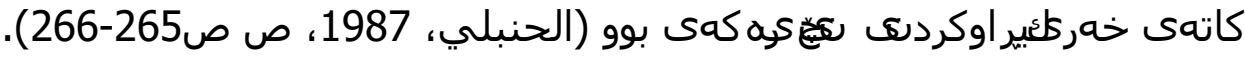

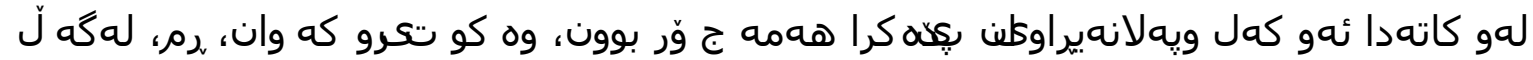

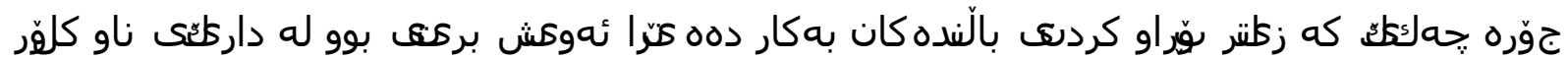

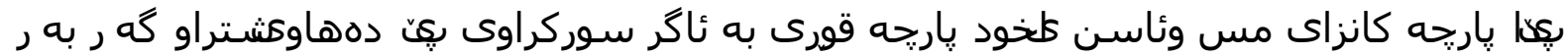

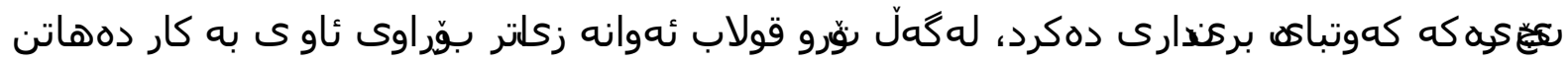

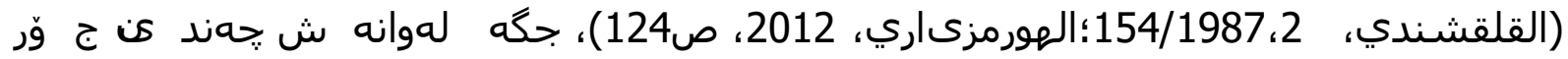

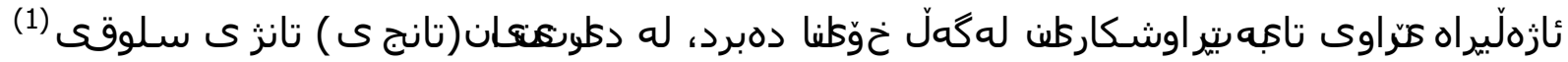

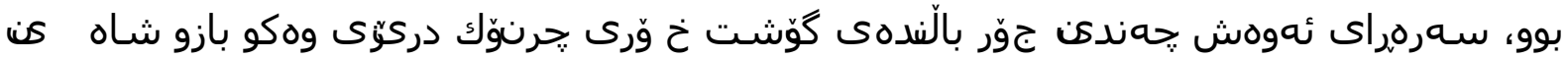

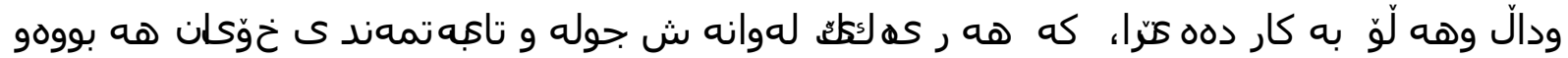

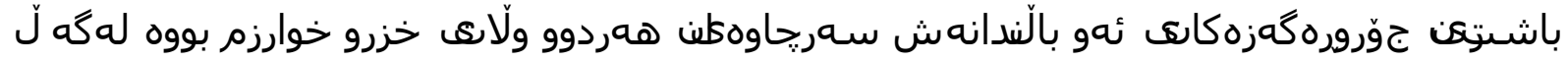
جكلكانى دهوروبهرى ئهرمكنعل(المسعودي، 2005، 269/1؛ الدمكوي، 2003، 200/

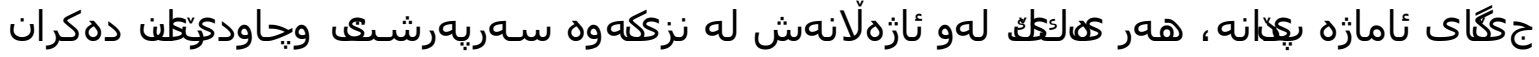

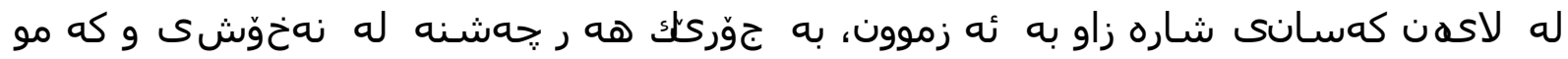

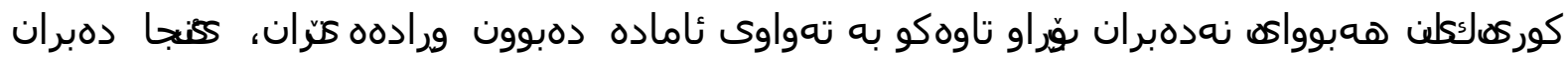

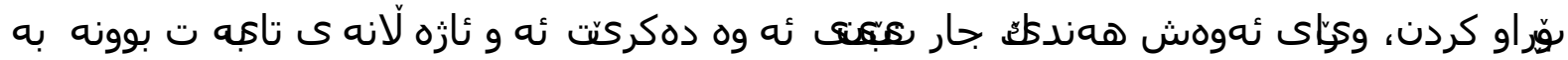

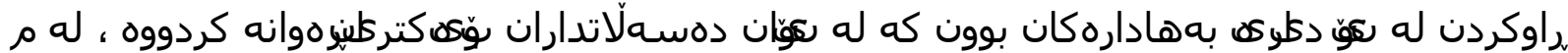

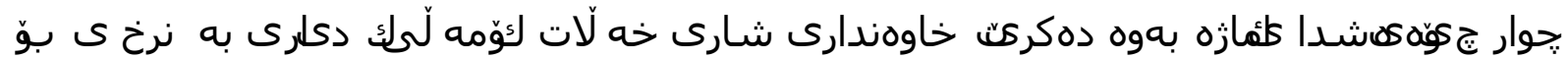

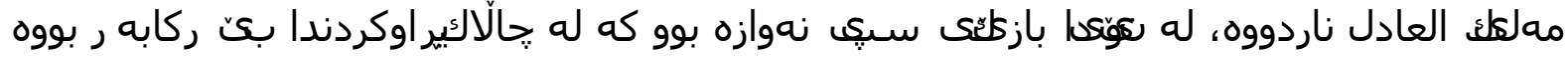

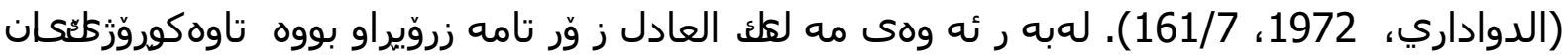

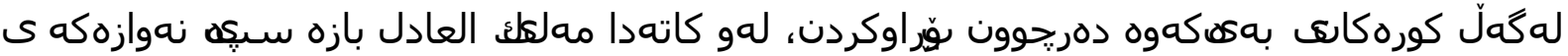

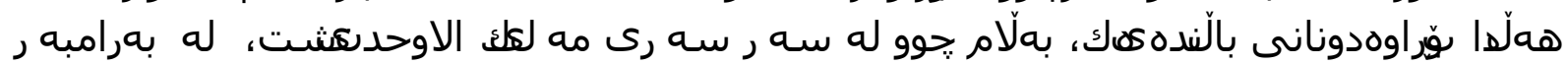

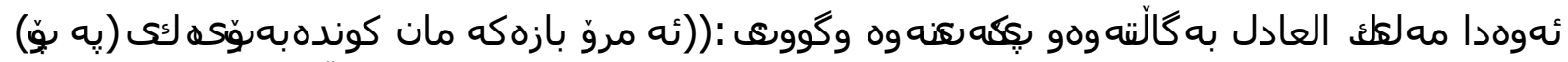

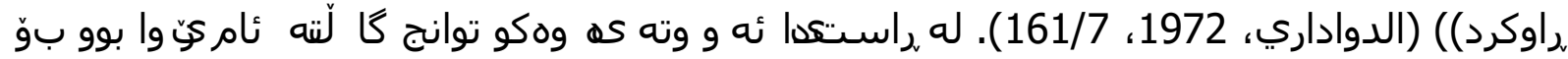

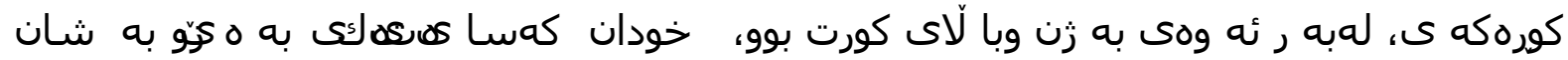

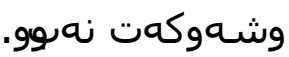

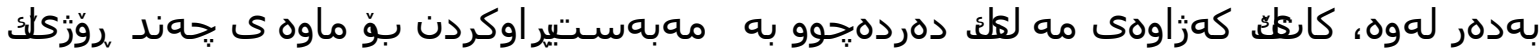

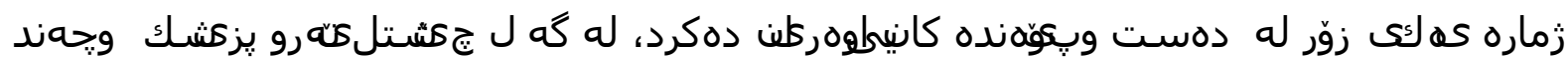

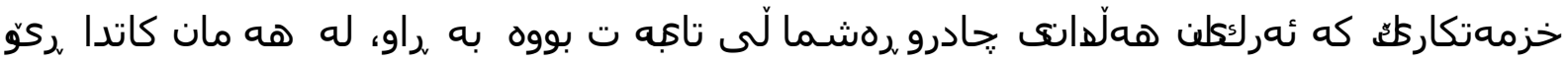

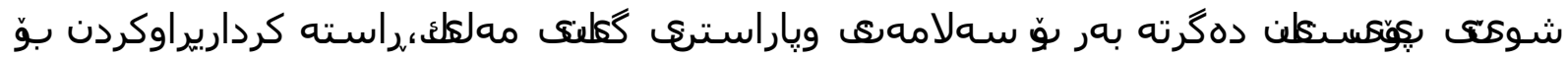

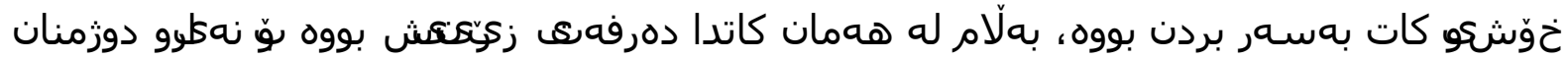

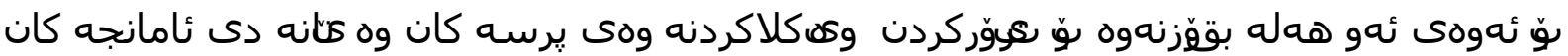

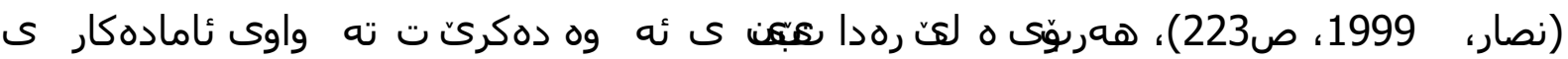

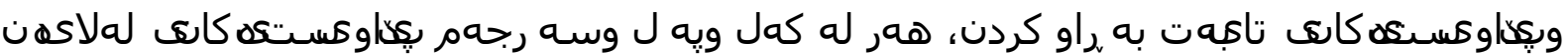

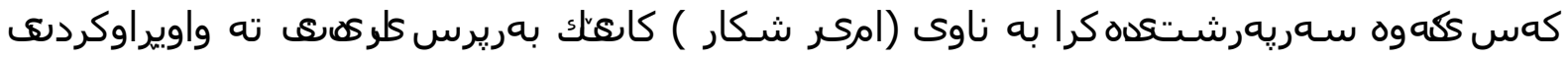

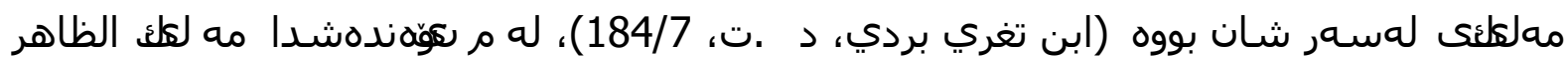

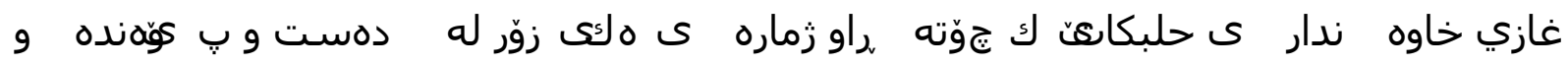

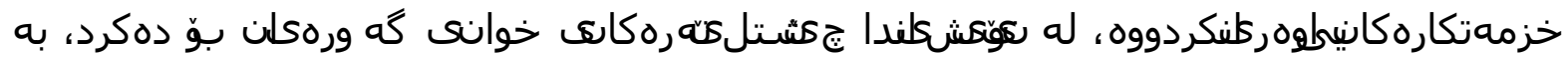

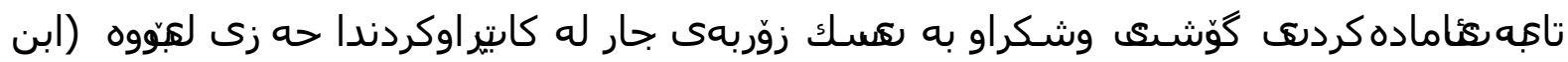
نظيف الحموي، 1981، صاوكندا (72). 


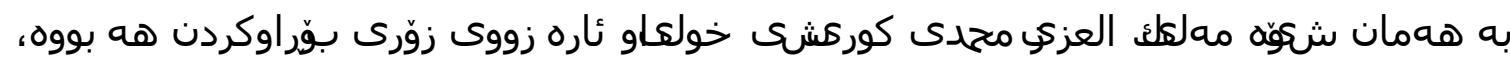

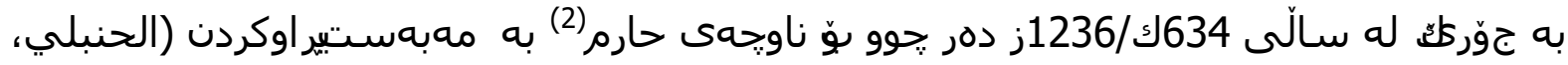

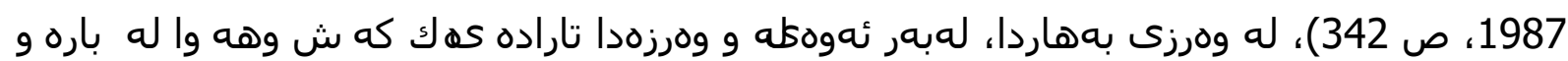

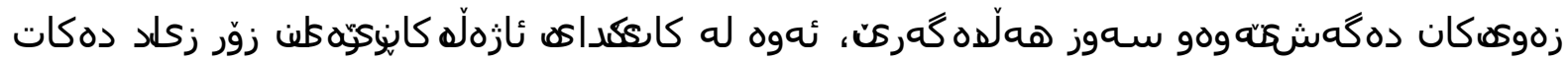

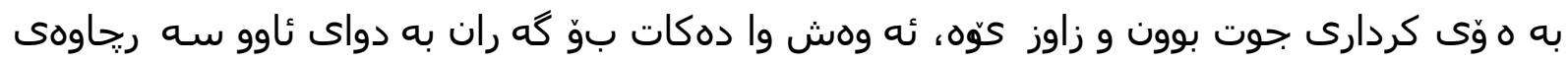

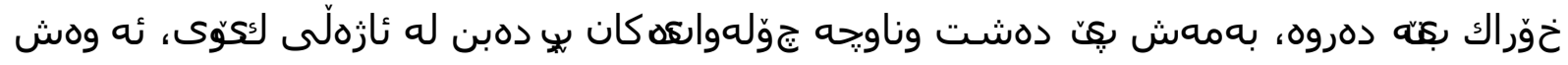

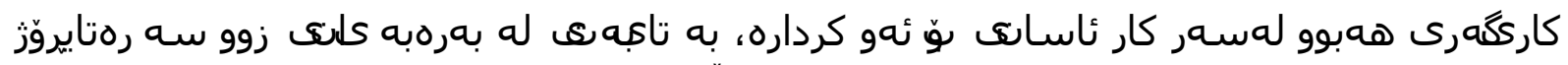

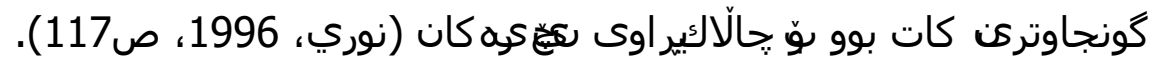

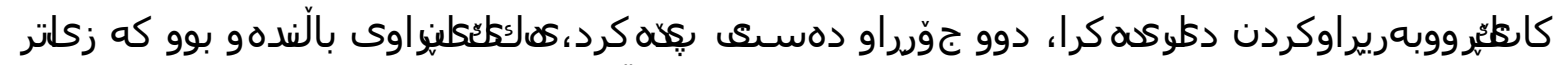

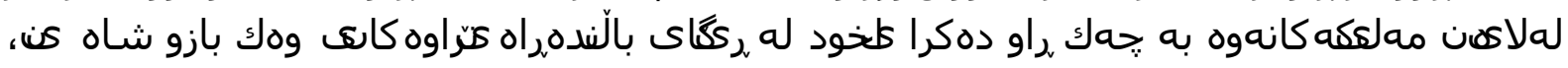

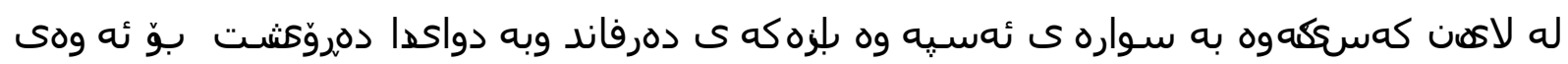

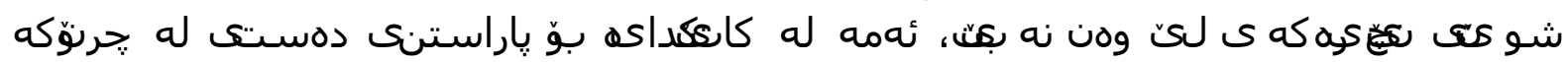

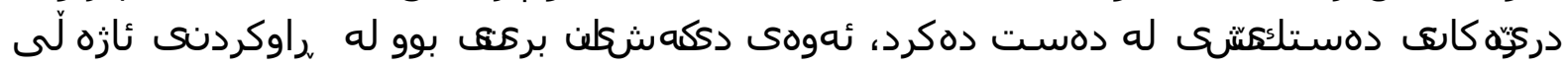

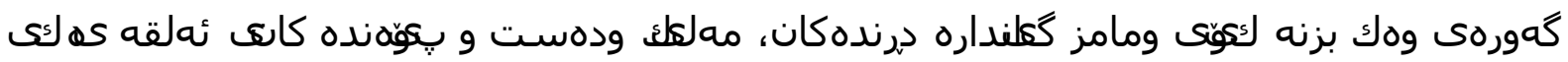

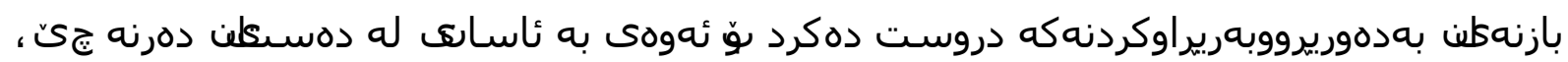

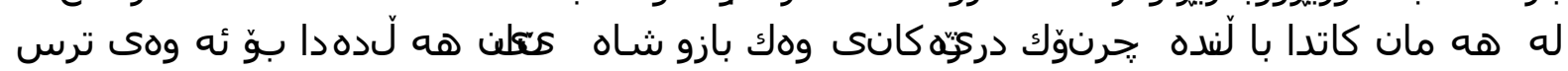

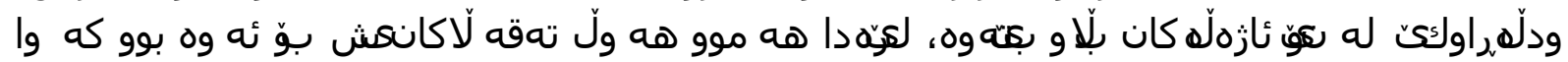

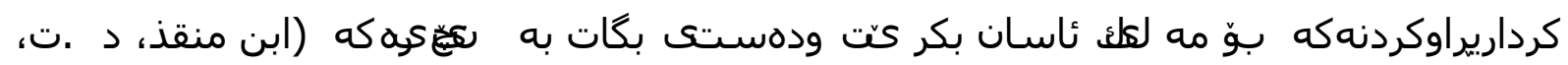

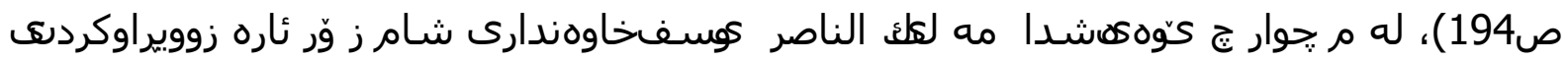

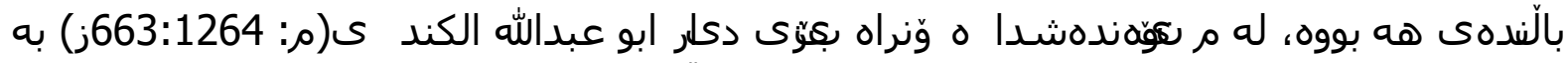

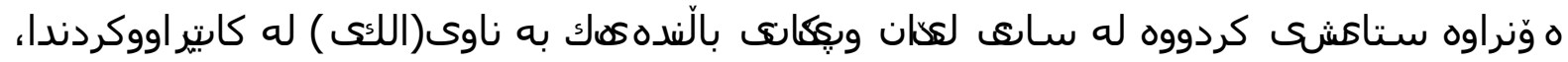

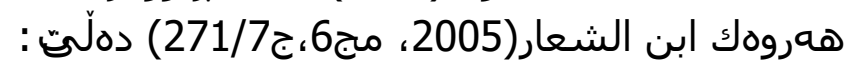

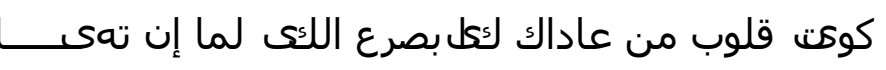

ونجمك فى العلا أبدا مضهل

طوكت به بساط الارض طل

فأخطأ لا ومولانا علىـ.

بكفك أو بنادقه الثرىـــ
فلا زالت سعودك سـابقــــات

ملكت الناصرالسـلطان عدلا

وسـم لم كوقعوم حرب

كــأن مجرة الافلاك قوس

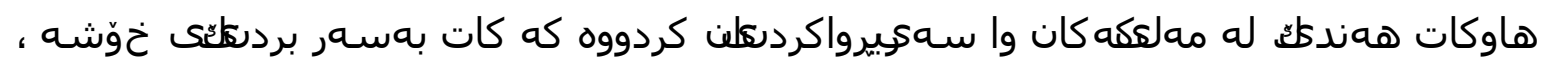

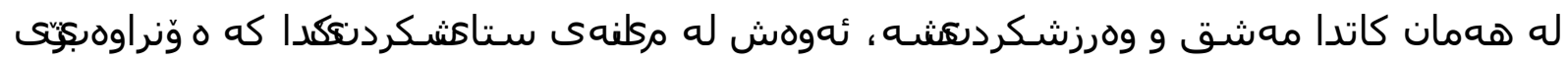

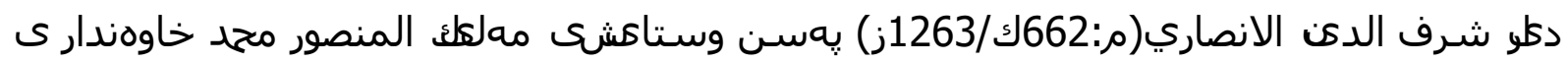

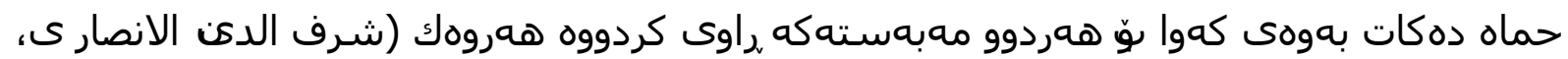

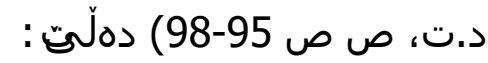

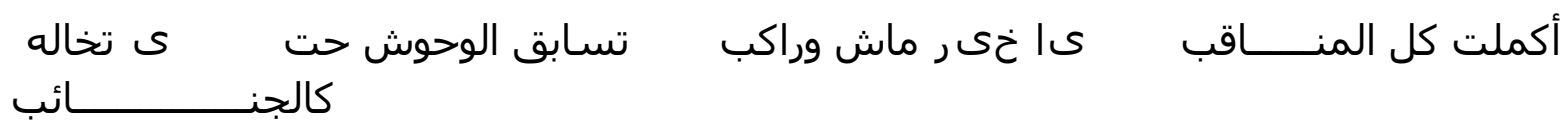

وكم ضربت علــــها من حلقه بالـــمقانب جلبت فهها صنوف الا ضداد لـخو جالـــب 


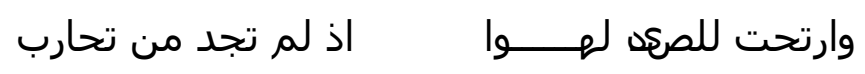

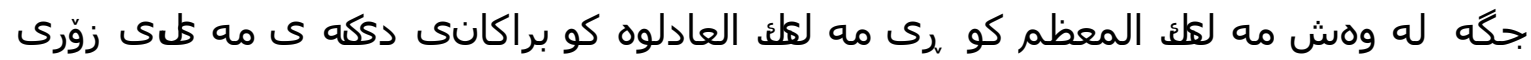

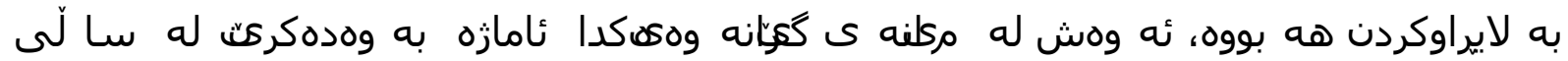

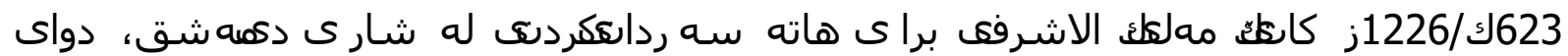

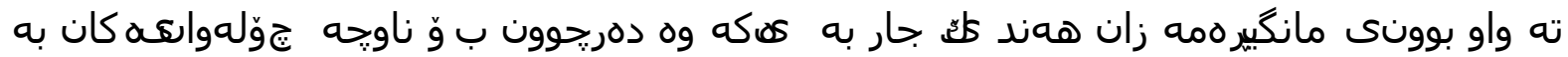

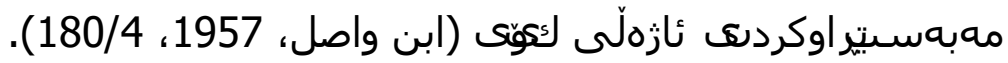

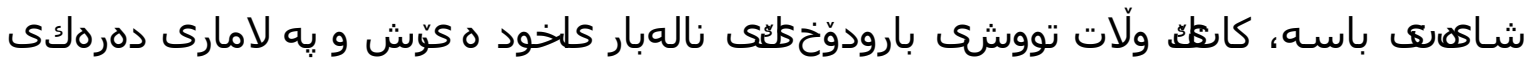

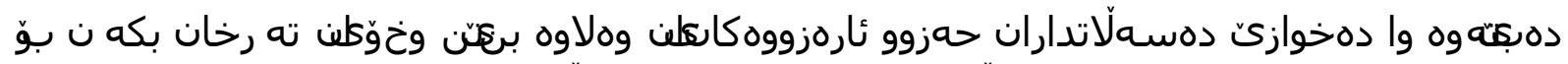

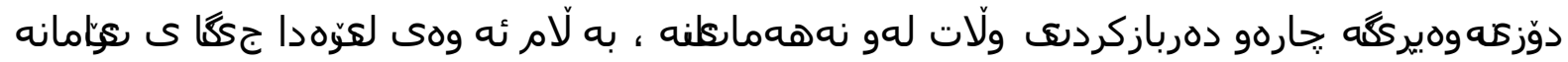

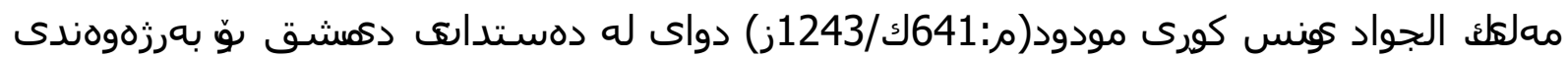

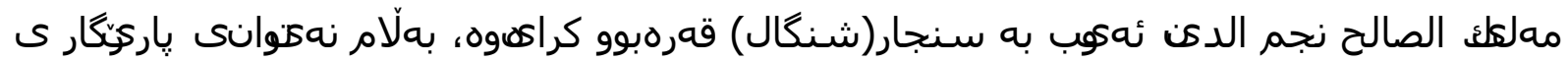

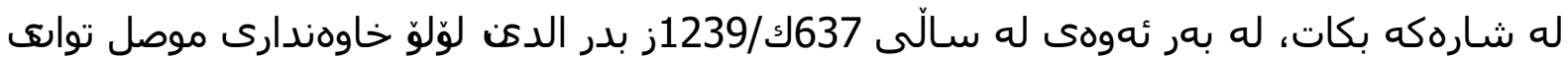

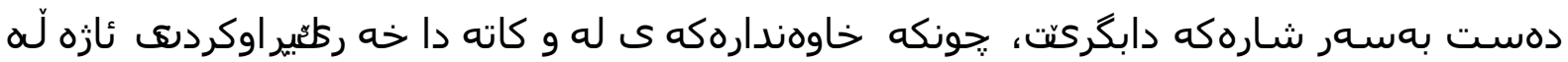

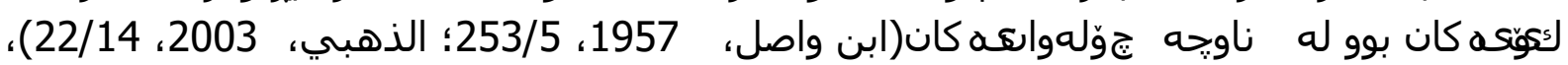

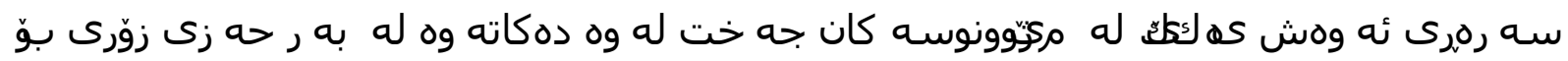

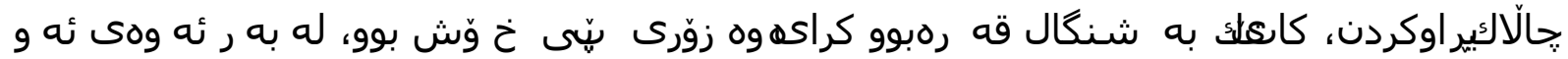

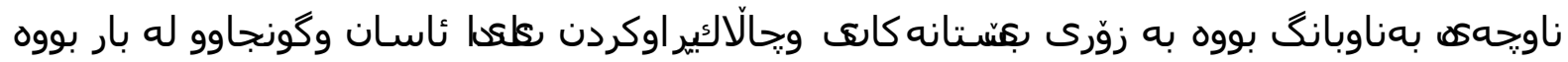
(مؤلف مجهول، 2010، صاسنان وكار باون.

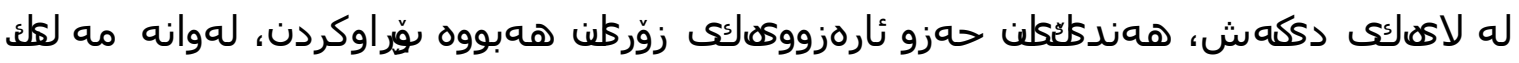
الامجدخاوهندار ى بعلبك (النويري،

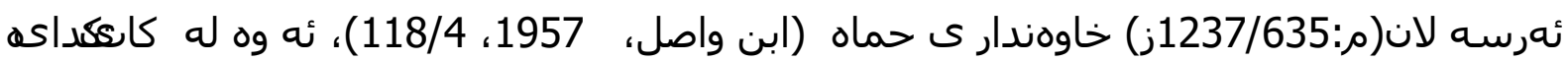

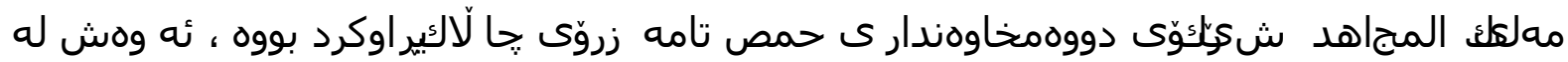

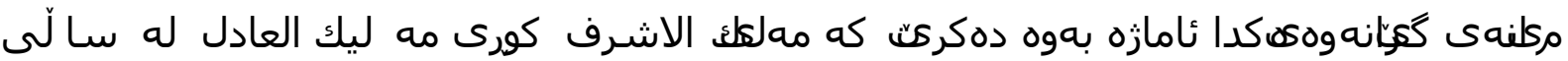

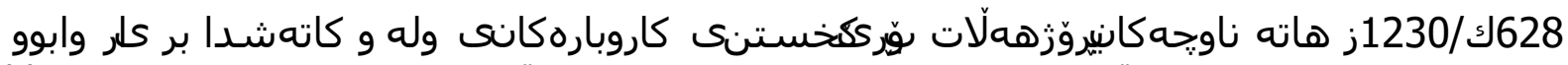

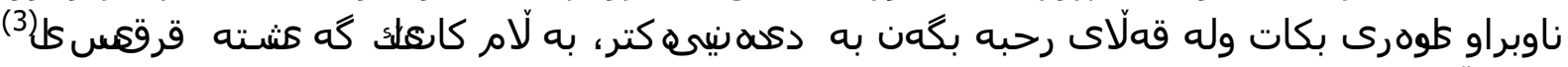

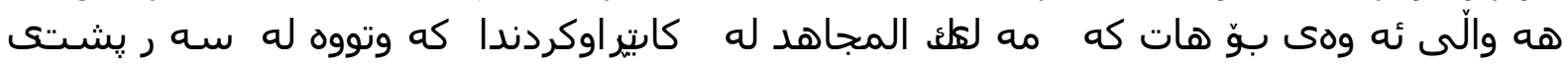

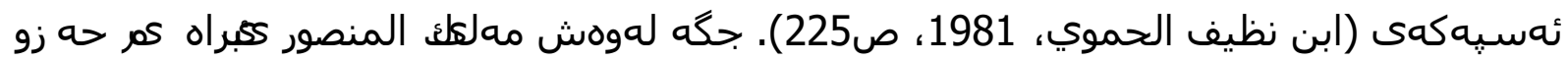

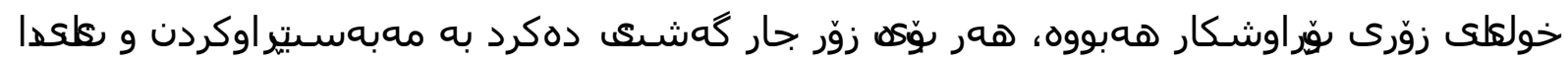

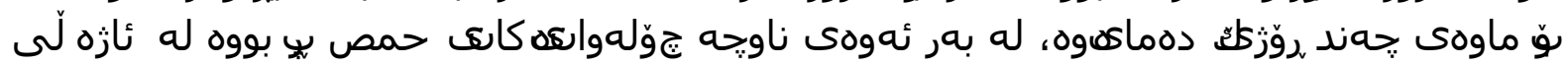

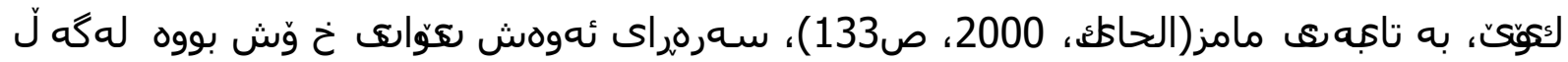

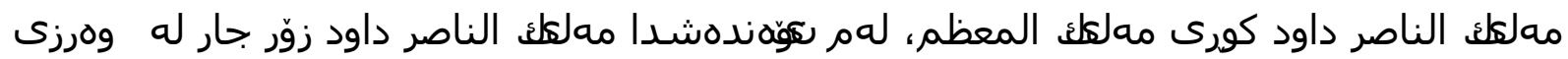

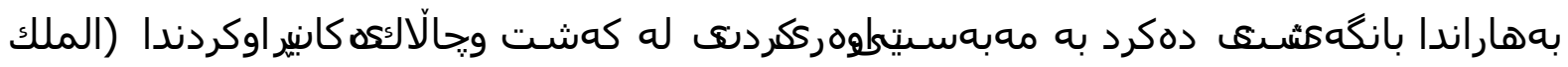
الناصر داود، 1992، صانيراودندا (الملاك).

\section{2_ سوارجاكى و هونهركانى سواريحاكى}

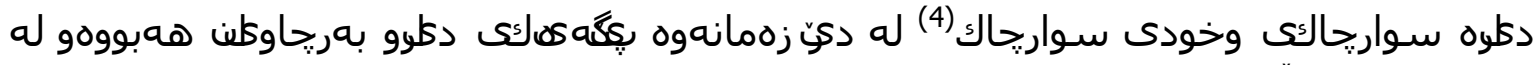

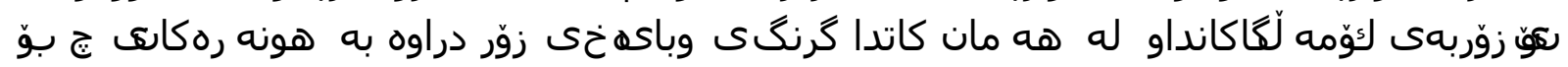

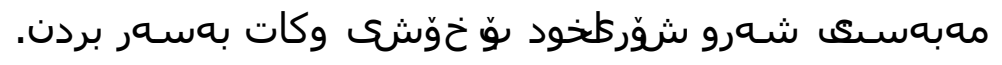


له رووانكهى sكسلامكشه وه، جه ختكراوه لهسه ر مهسه لهى سواريخاكى وتهنانه ت ئه رك

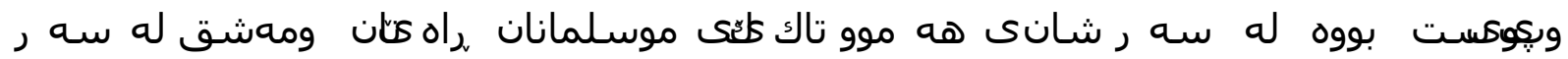

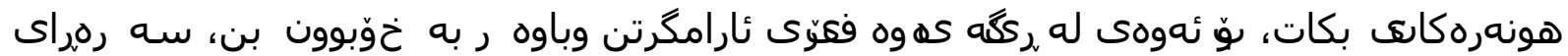

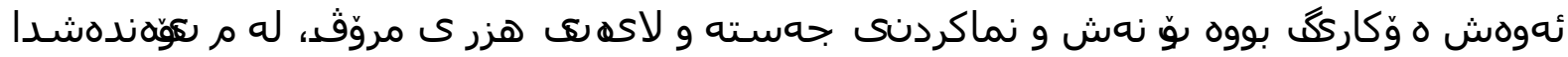

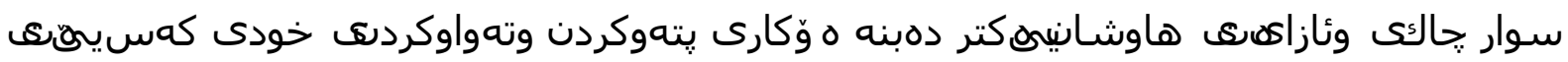

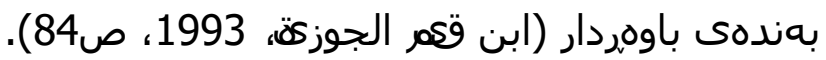

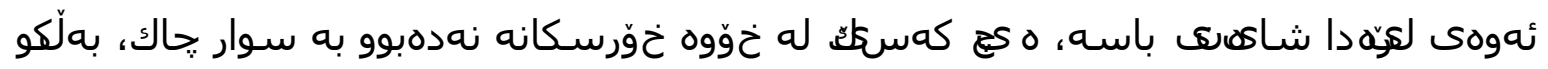

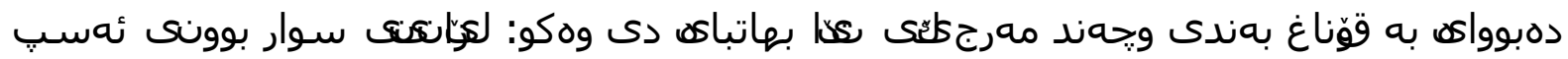

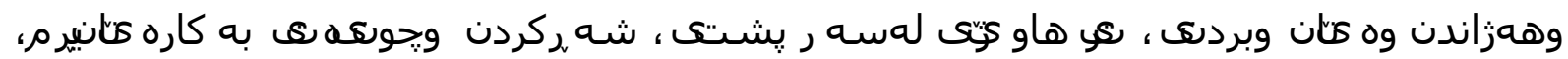

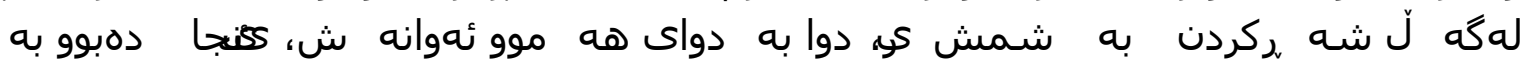

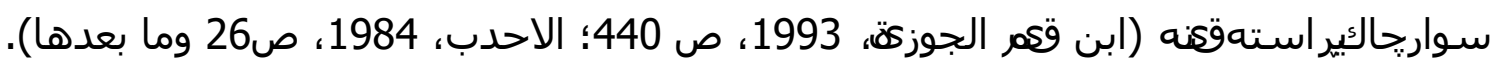

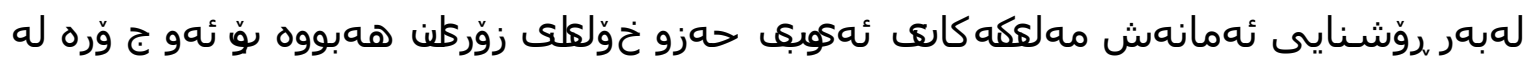

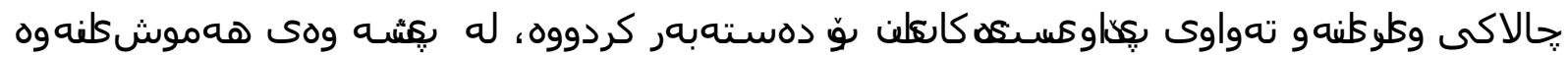

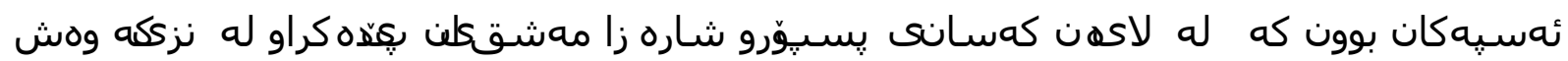

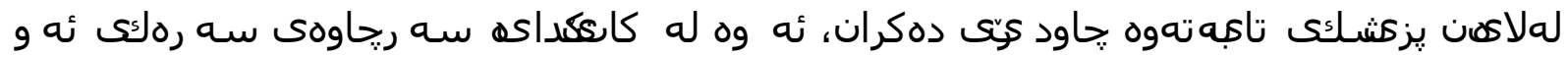

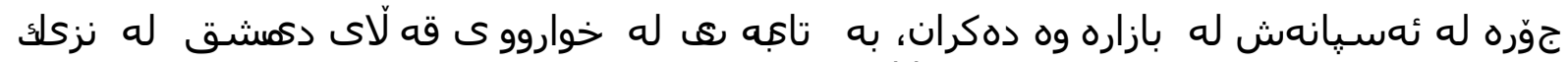

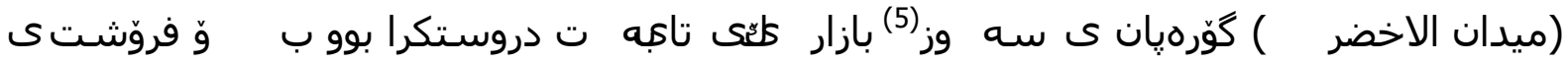

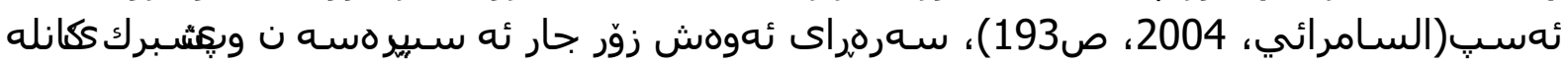

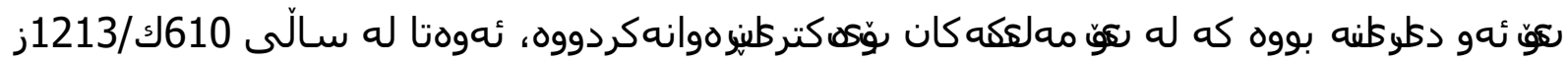

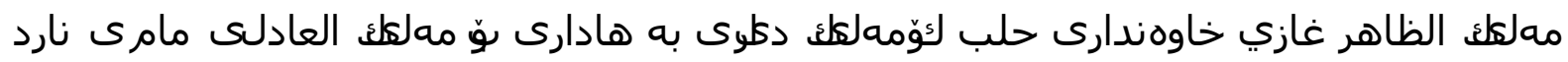

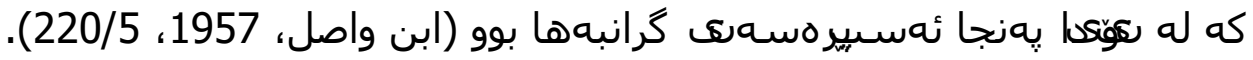

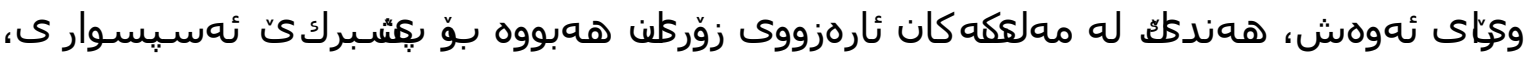

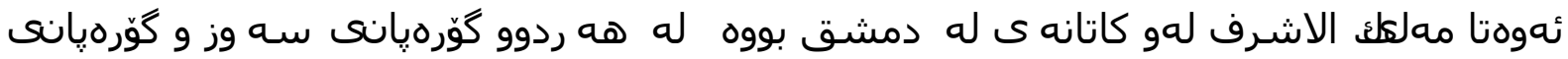

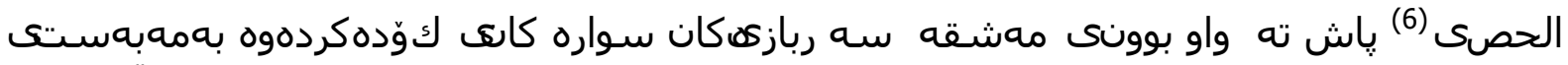

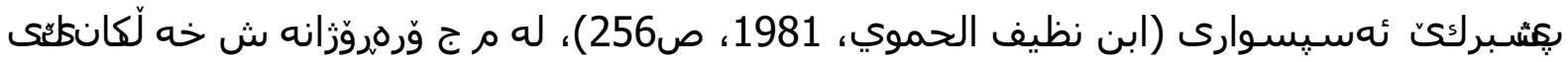

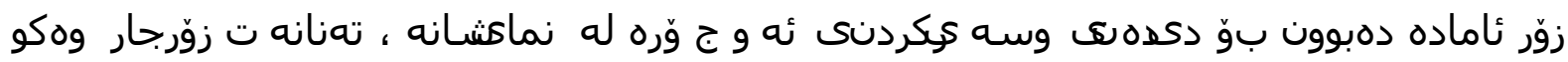

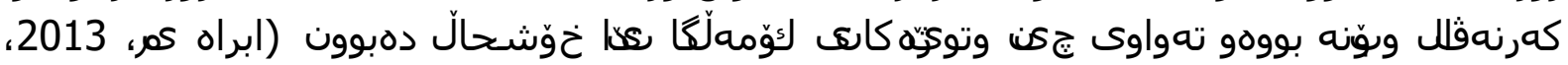
ص266)

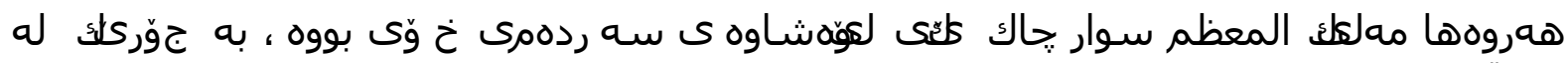

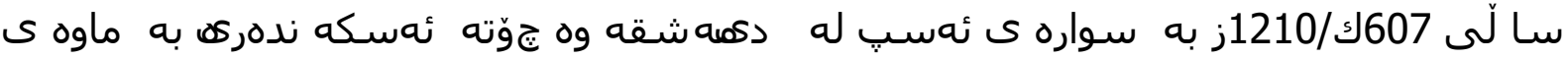

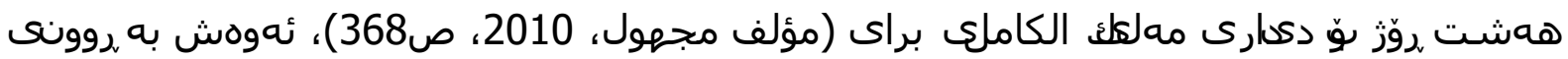

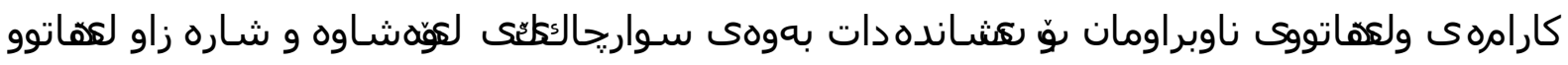
بووه.

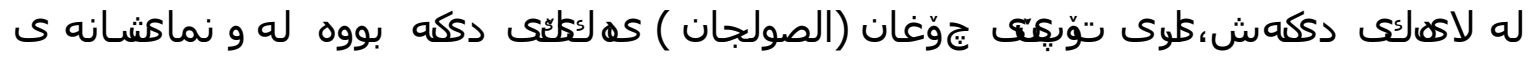

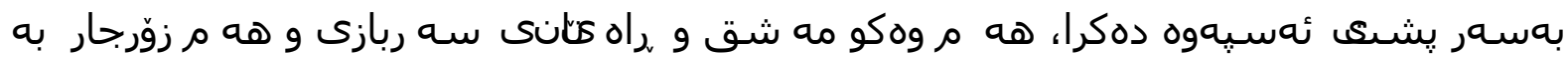

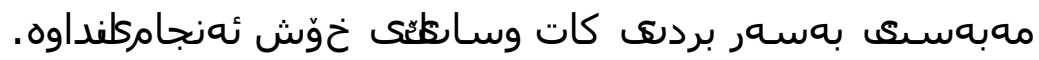

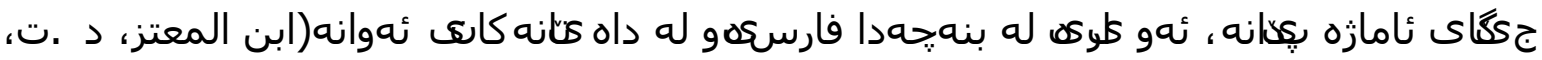

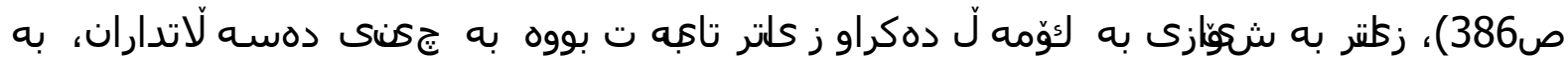




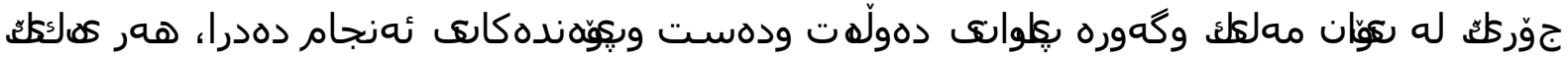

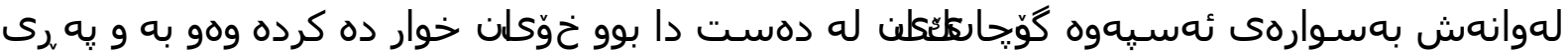

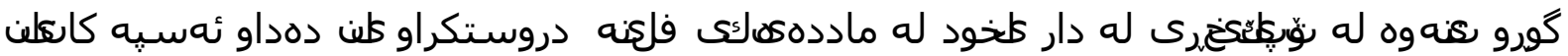

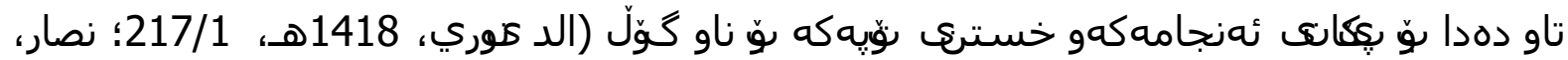
. 1999، 245،

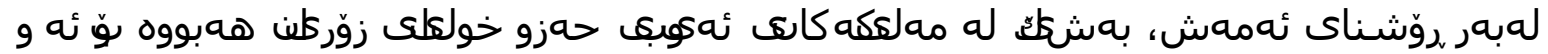

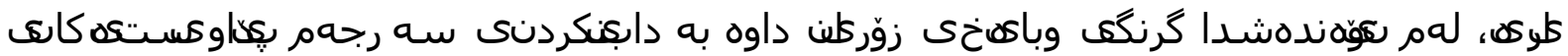

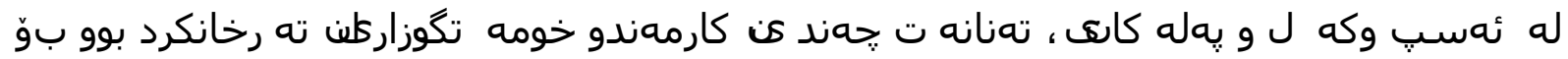

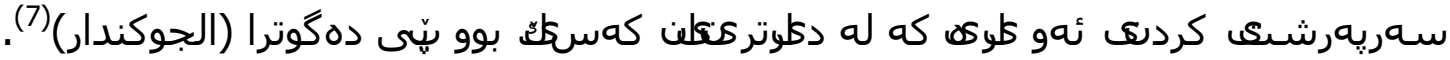

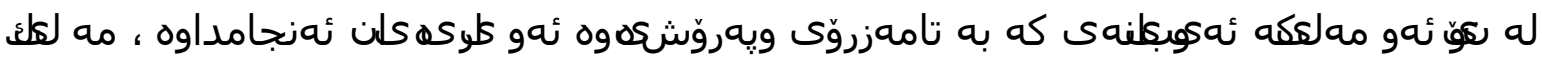

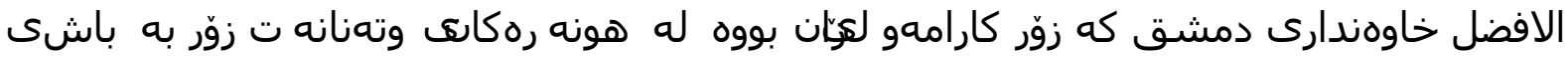

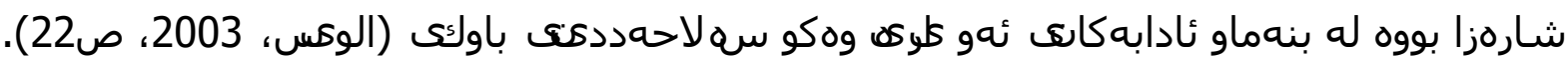

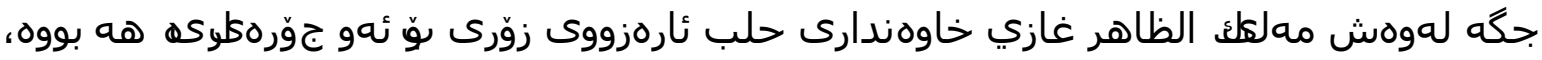

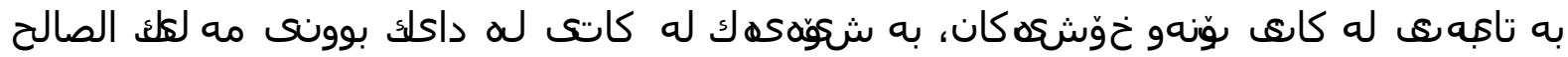

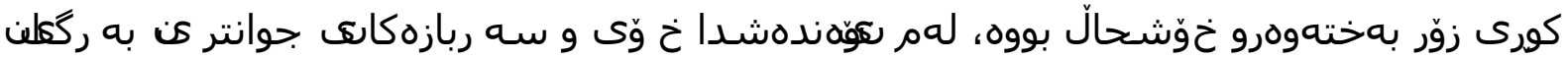

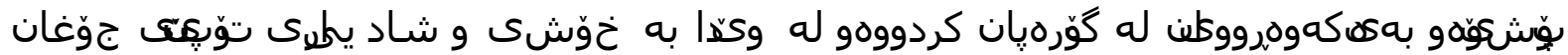

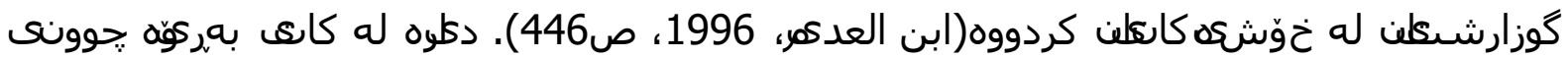

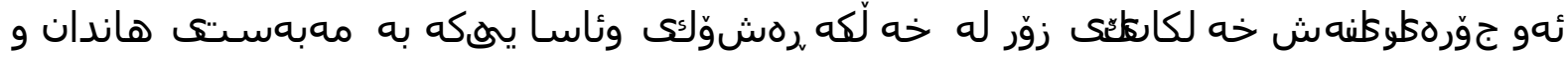

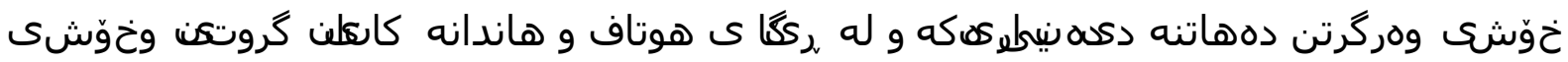

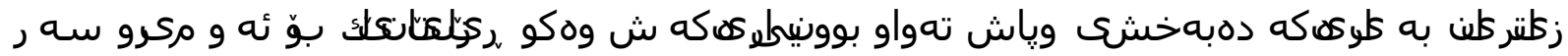

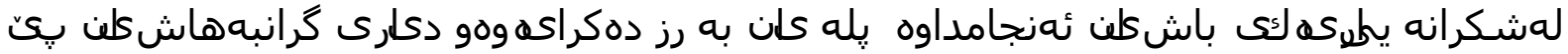

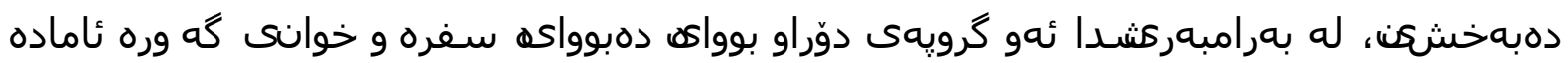

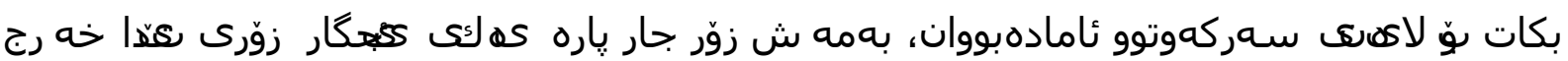

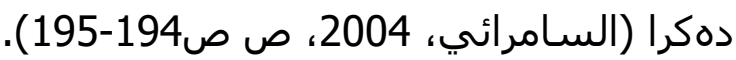

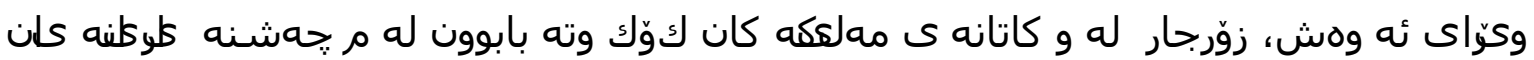

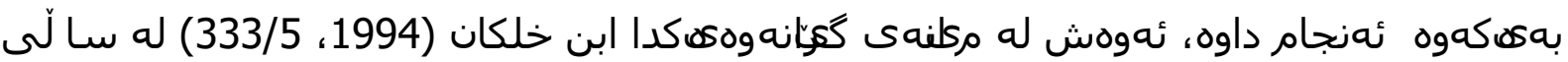

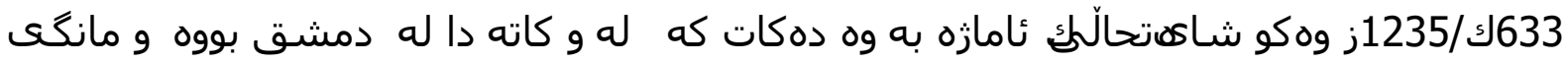

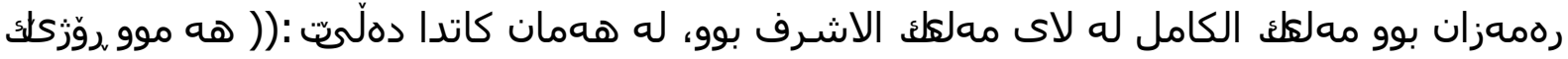

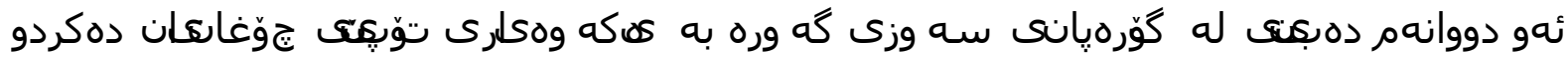

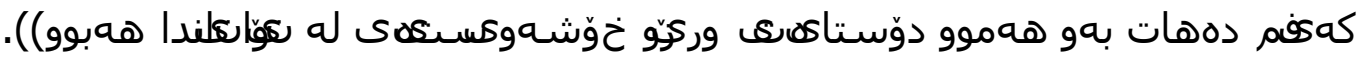

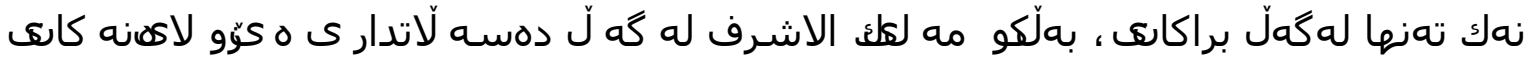

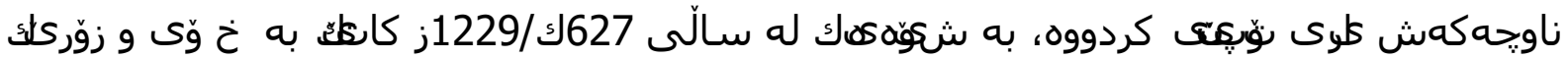

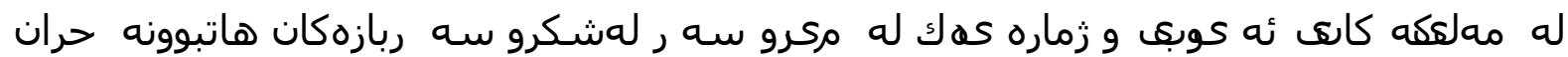

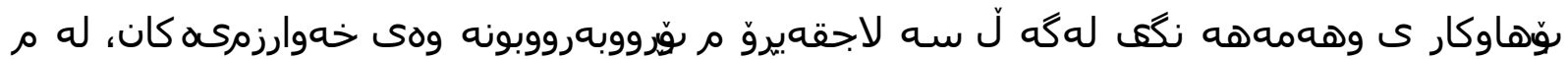

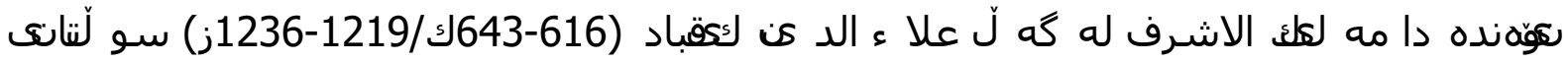

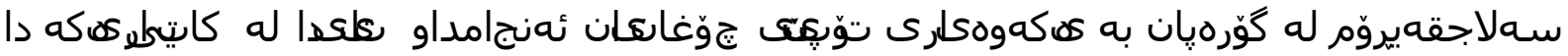

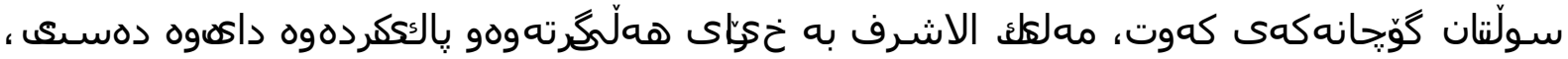

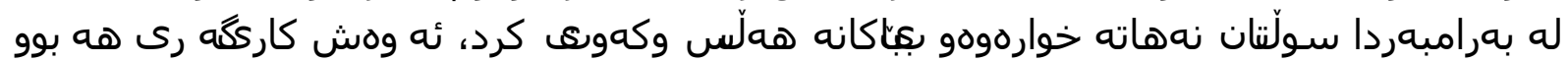




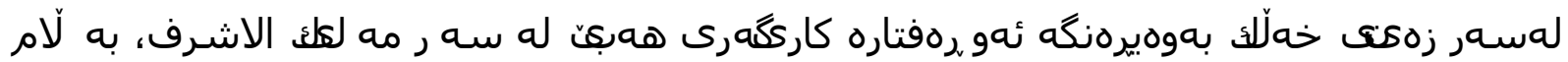

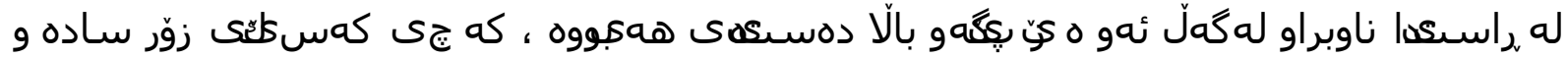

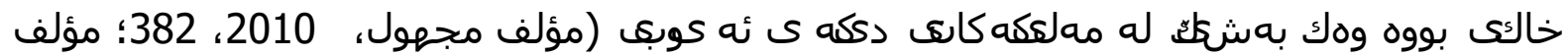

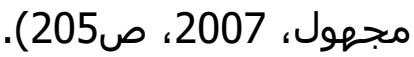

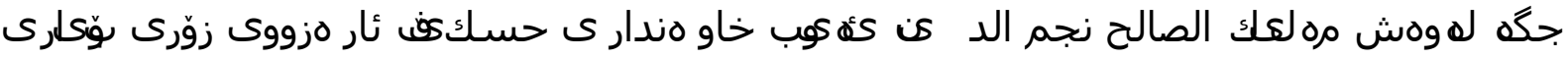

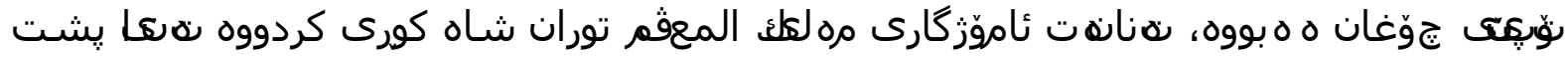

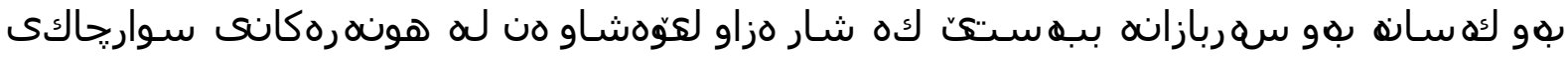

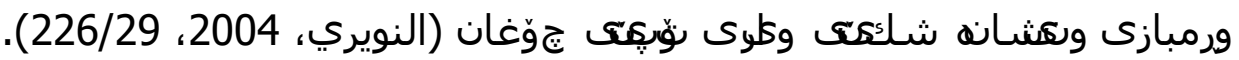

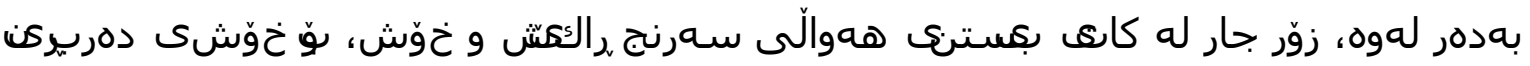

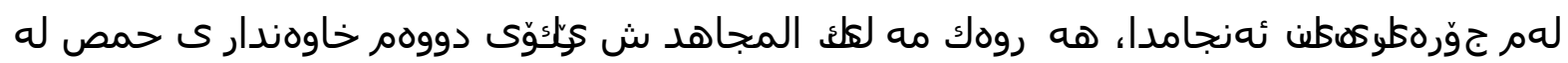

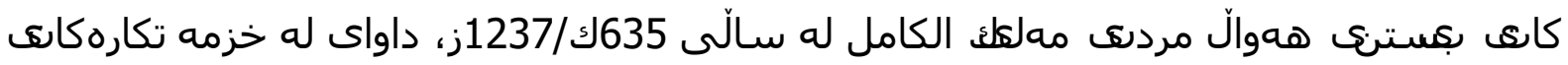

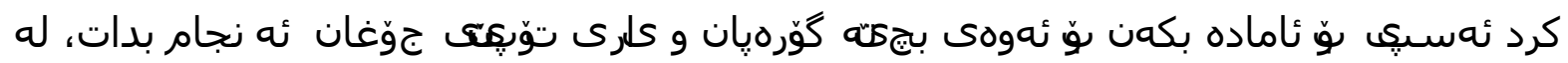

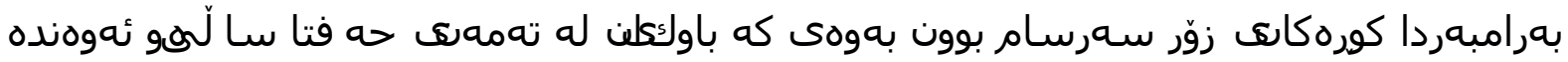

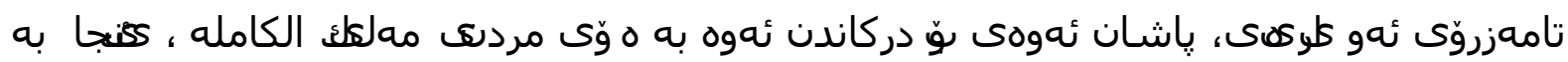

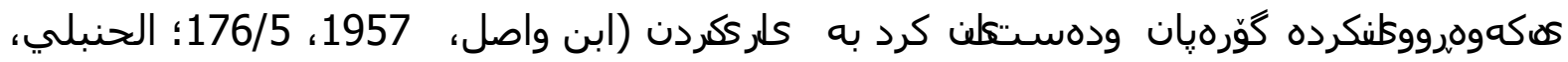

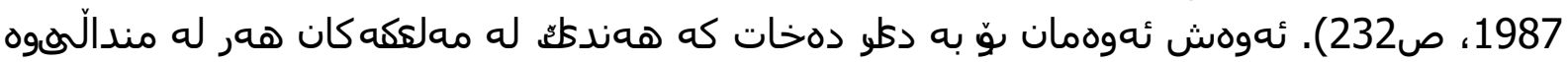

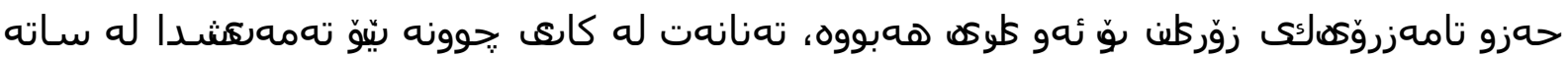

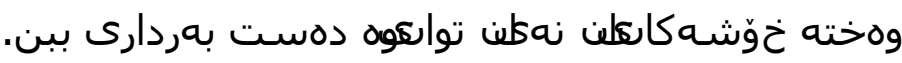

\section{3_ كلهانه شككنى (لعبة البندق)}

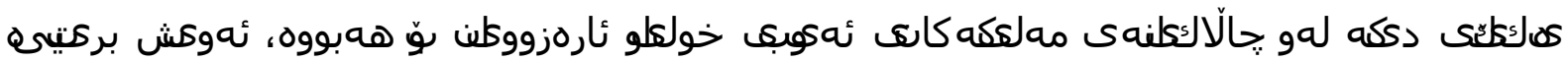

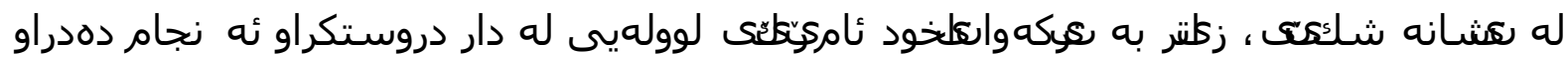

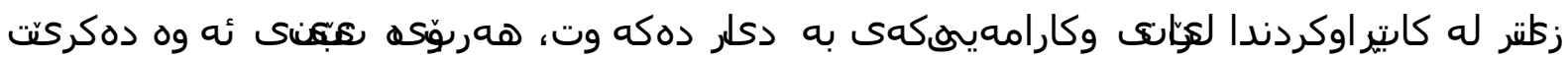

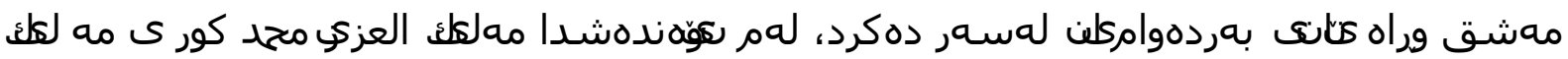

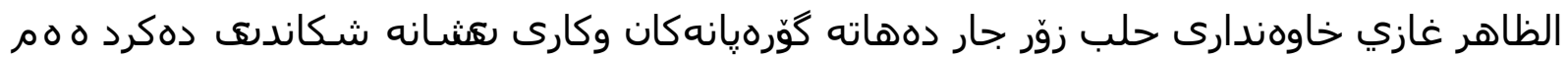

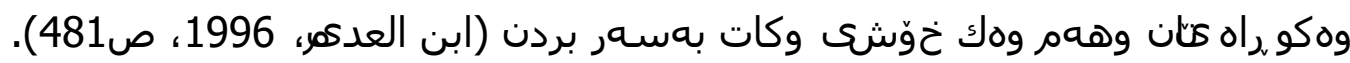

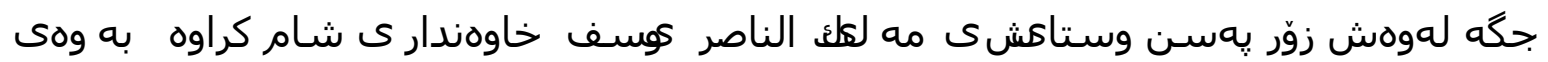

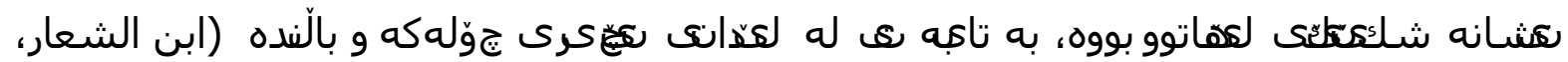

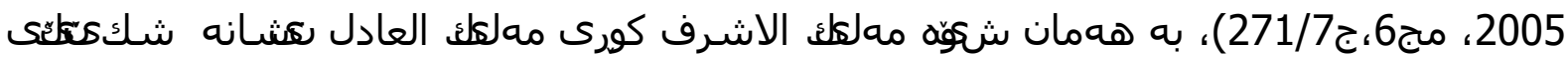

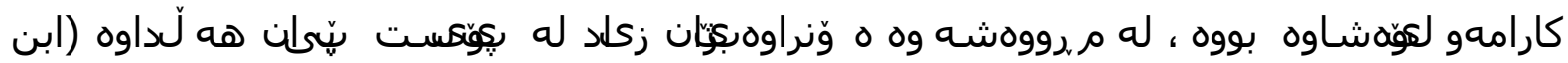

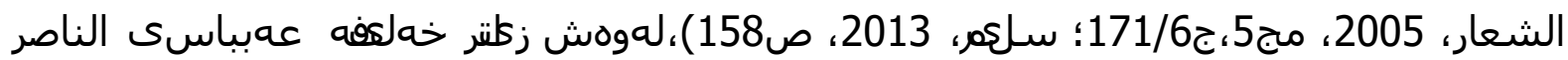

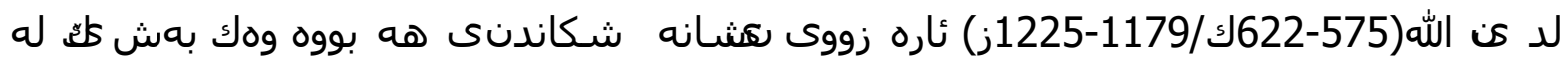

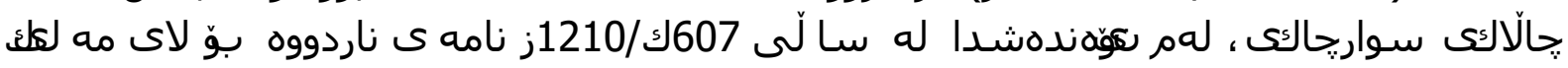

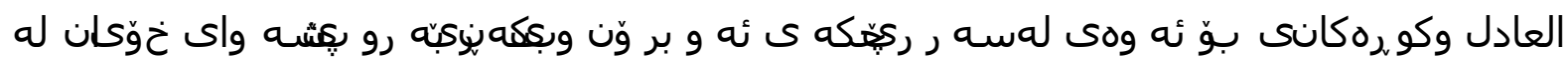

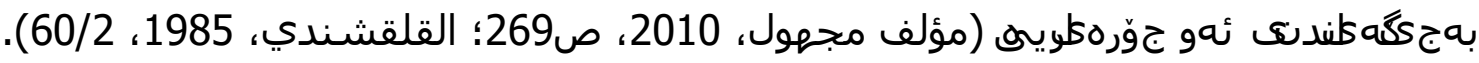

\section{4 _ كلريه زمكنه كان ئهوانهى به م كمّنى ئهنجامدراون}




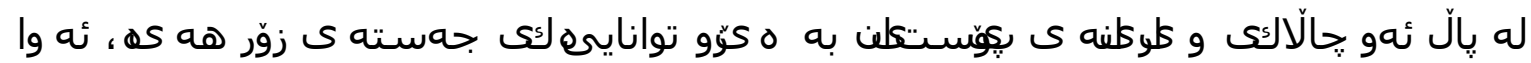

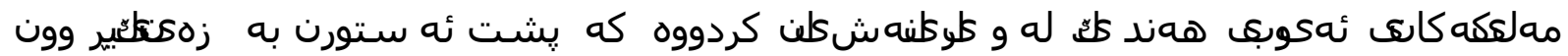

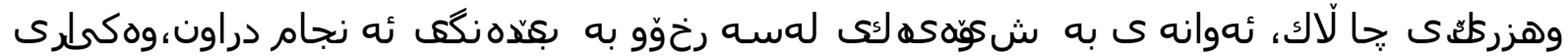

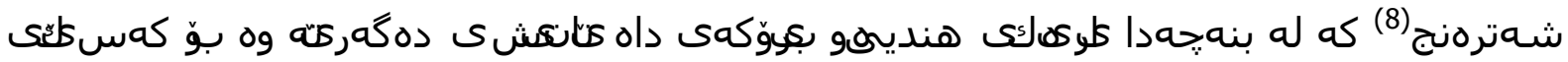

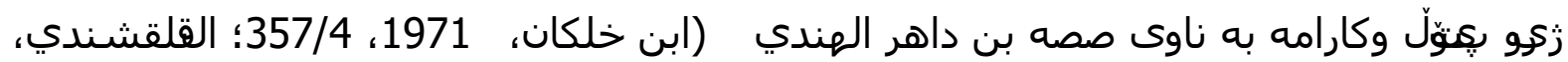
.). 1987

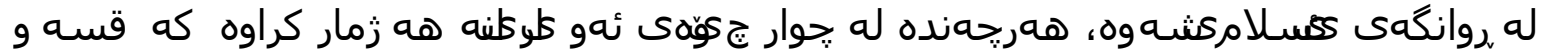

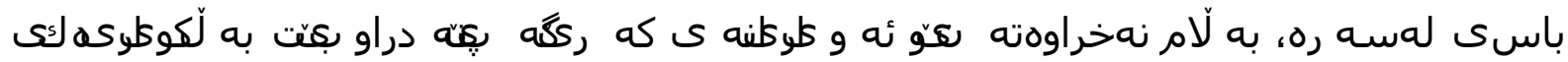

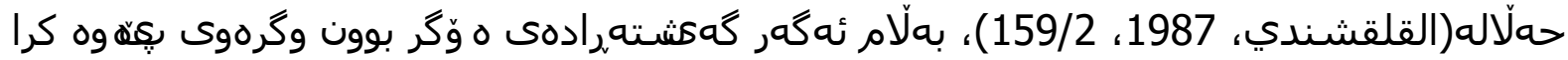

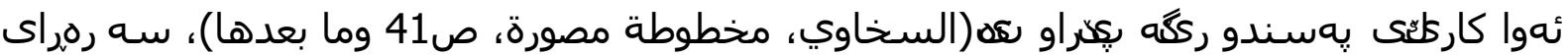

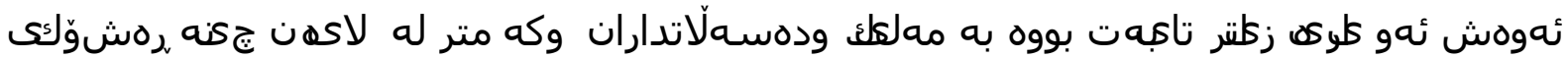

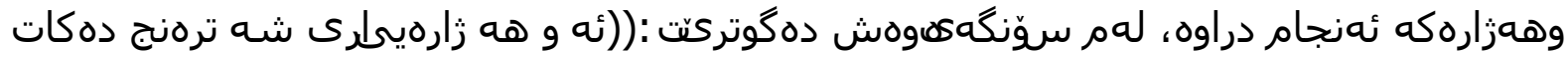

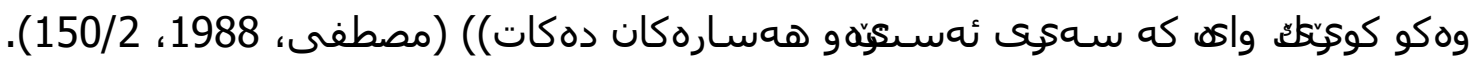

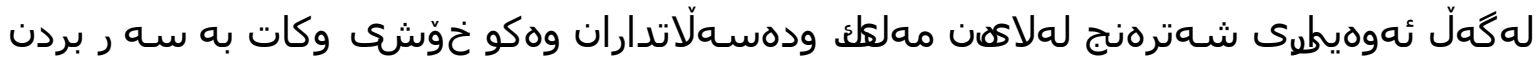

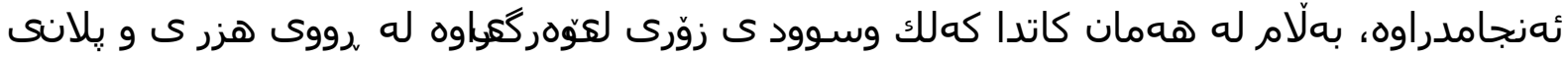

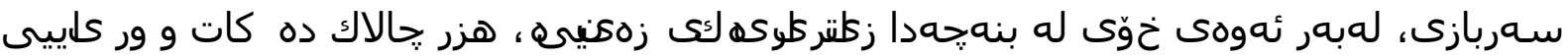

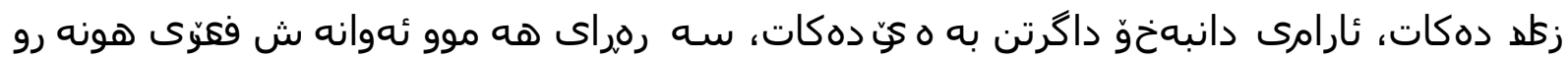

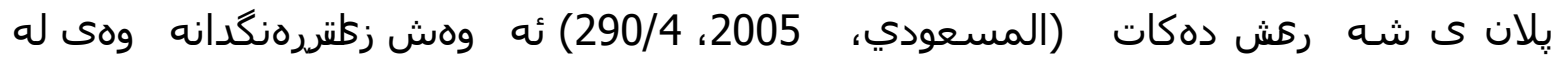

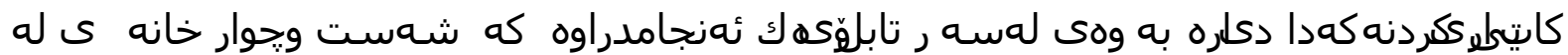

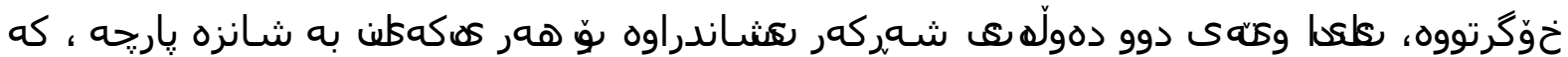

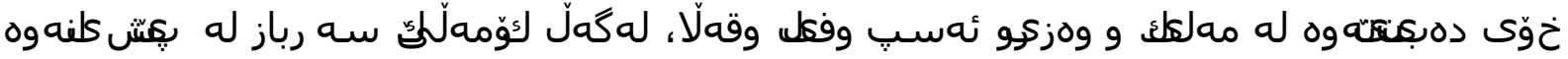

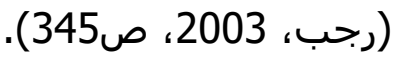

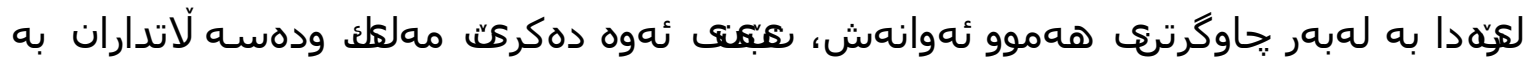

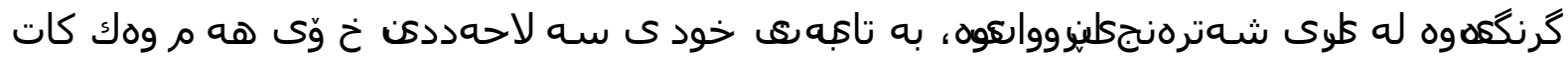

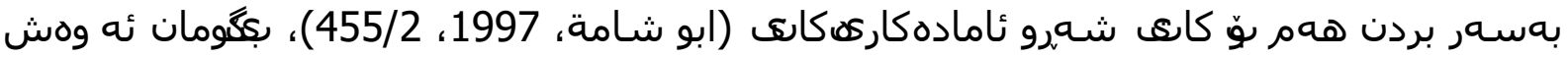

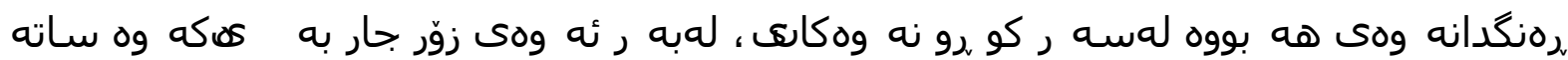

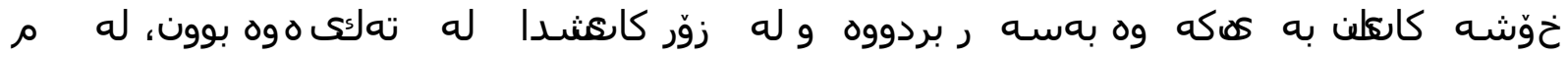

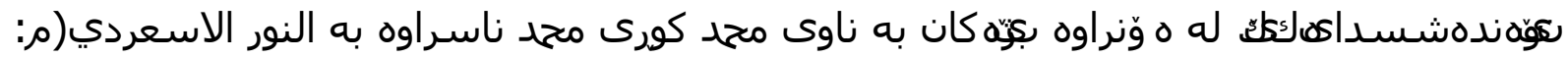

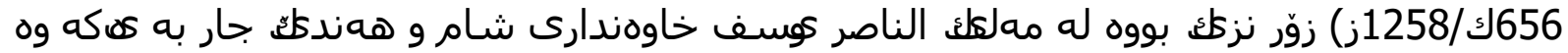

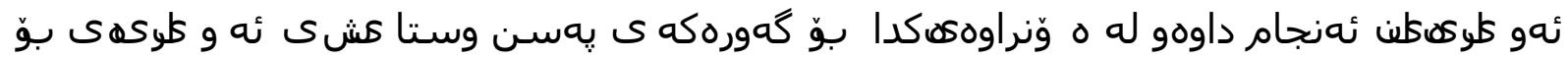

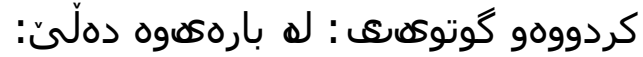

اهوي فأبدى حدوه تورىـــــــا

بقطاعها لما انثرع مجــــــودا

وجوانحى فهه تذوب صدودا
أعجبت إذ لاعبت بالشطرنج من

$$
\text { وغدا لفرط الفكر كضرب أرضه }
$$

فطفقت انشـده هناك معـــرضا

اوما تراها اعظما وجلــــــــا (الصاغغ، 1980، ص60) رفقا بهن فما خلقنا حدىــــدا

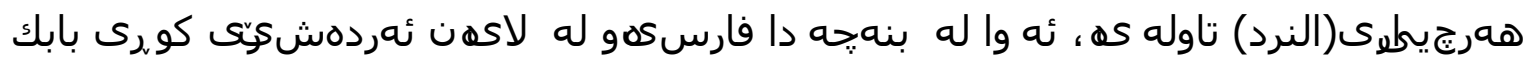

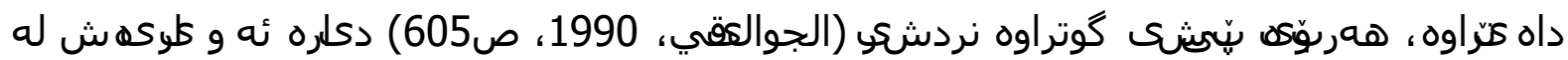




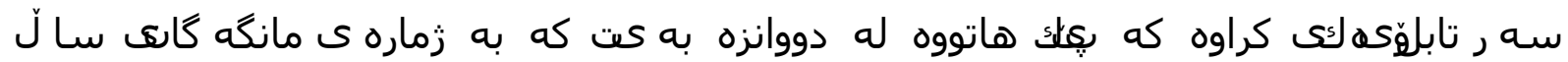

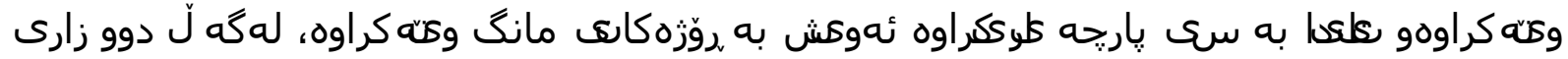

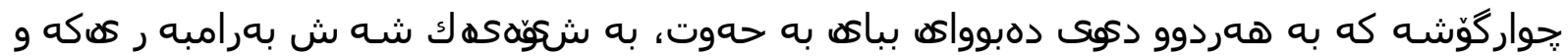

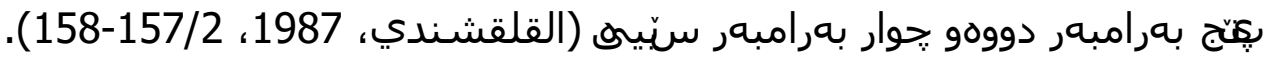

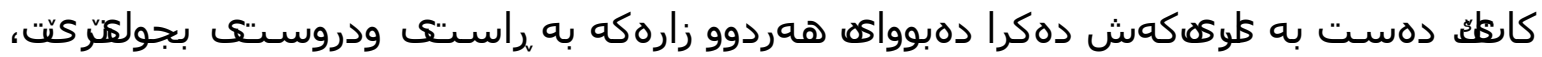

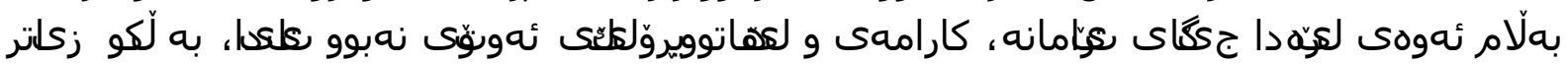

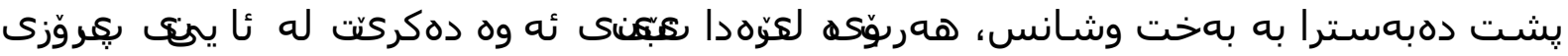

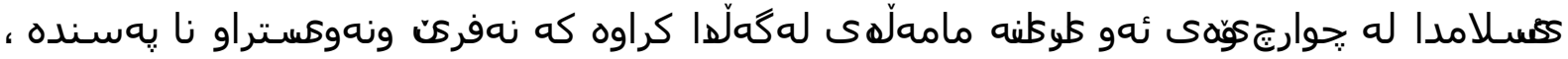

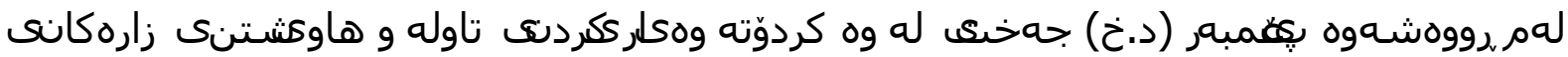

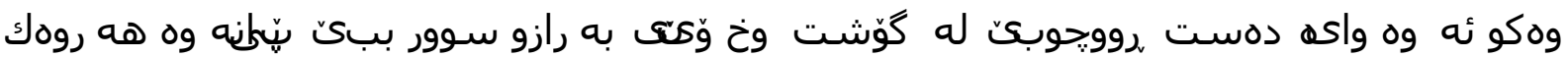

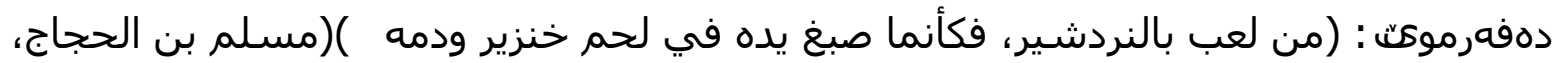

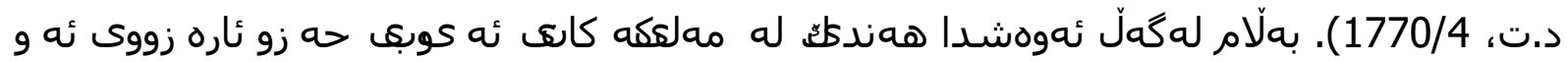

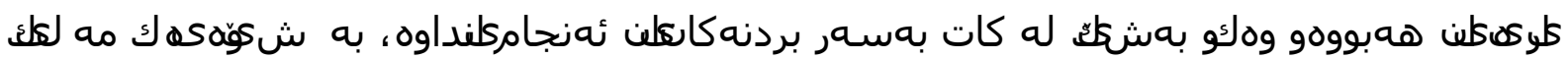

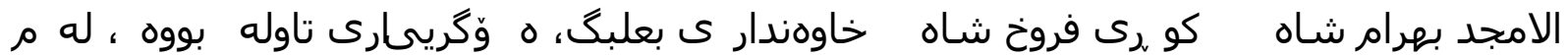

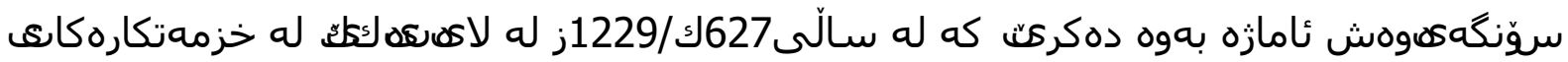

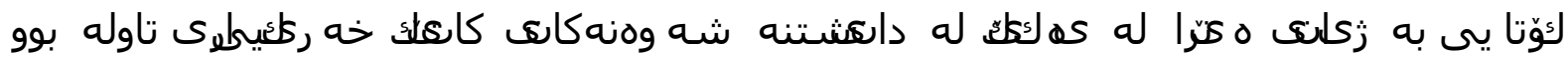

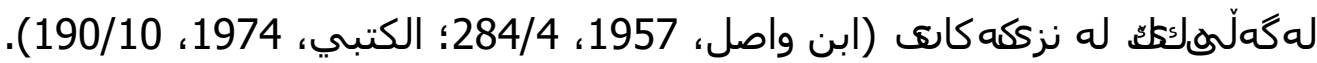

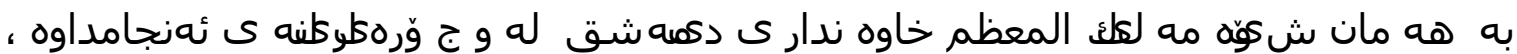

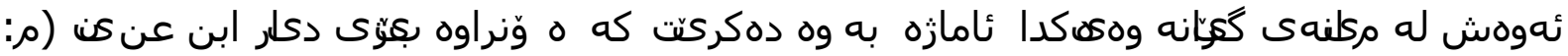

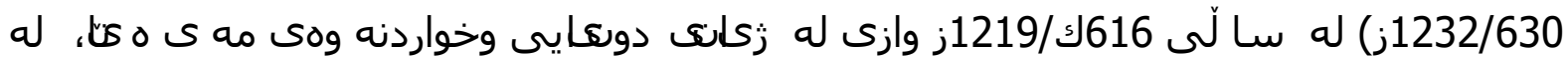

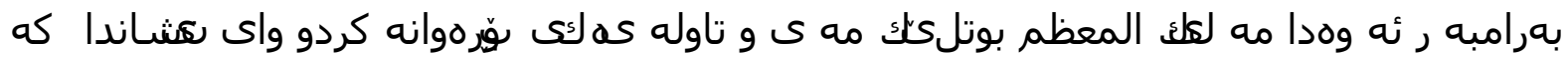

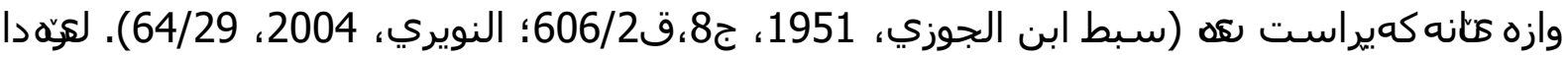

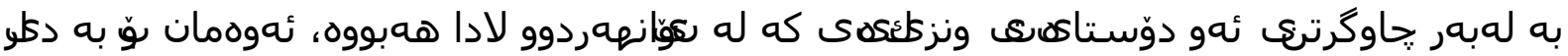

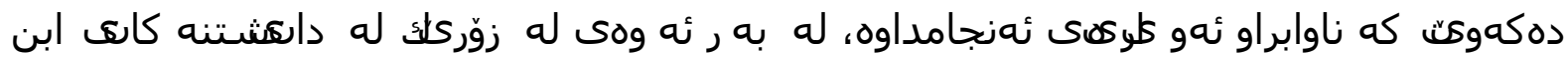

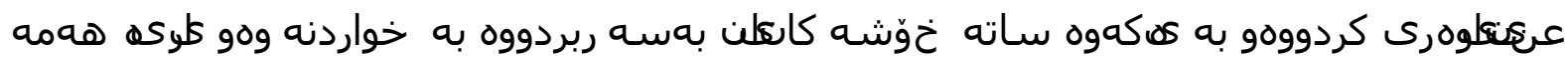
جوَره كان.

\section{5_ 5هشت وسمكان:}

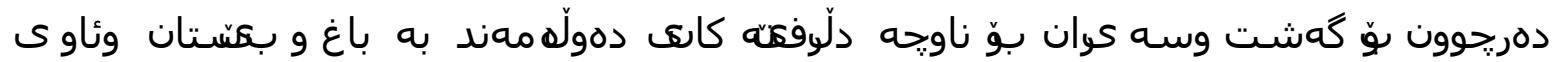

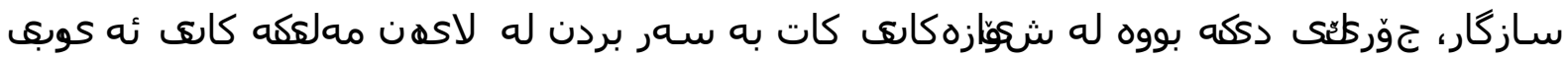

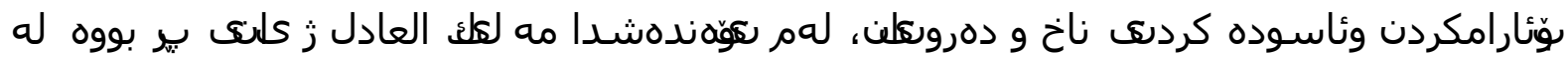

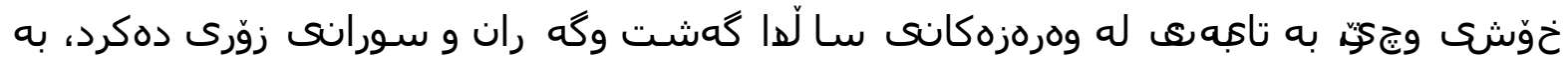

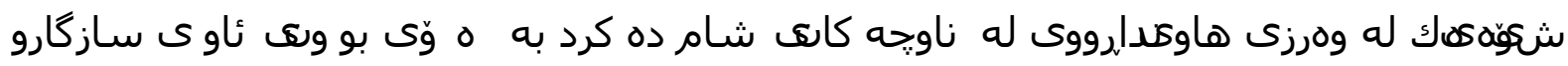

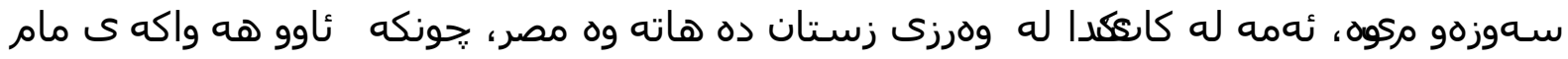
ناوهندو لهبار بوو (ابن خلكان، 1994، تهون 78/5).

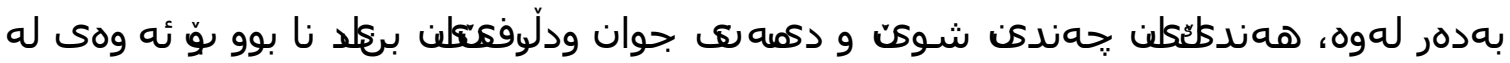

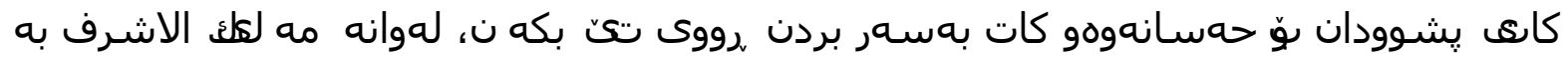

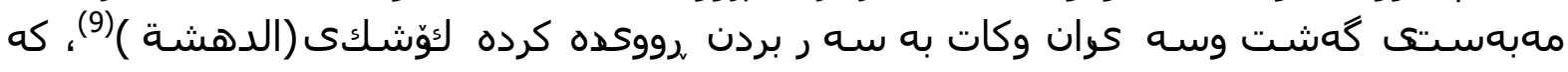




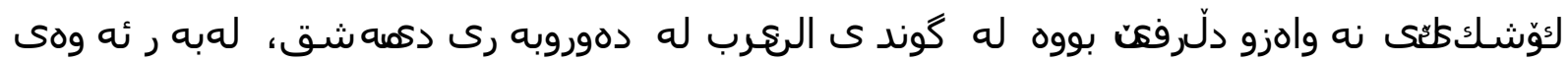

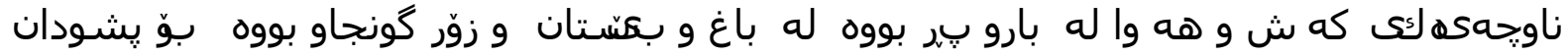
وحهسانهوه (ابن واصل، 1957، 195/ن، 144/5).

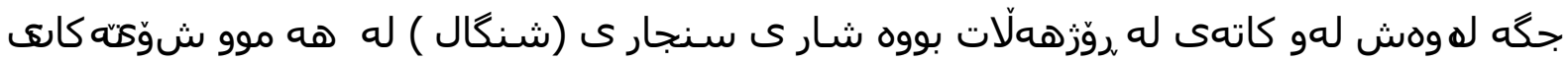

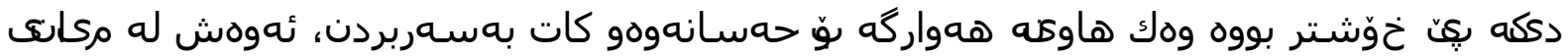

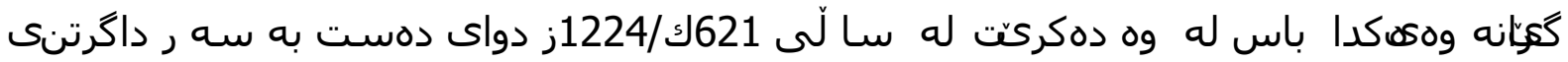

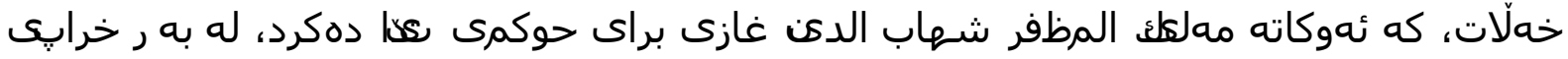

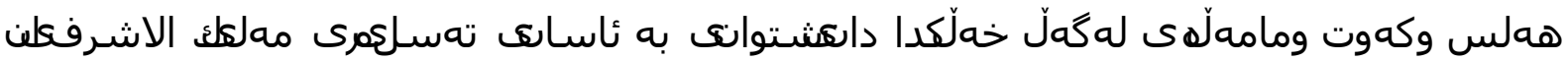

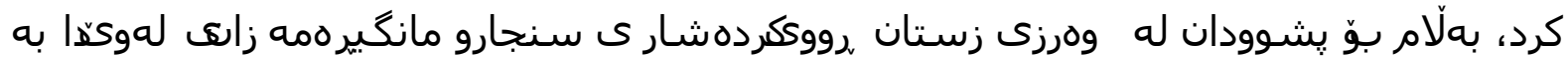

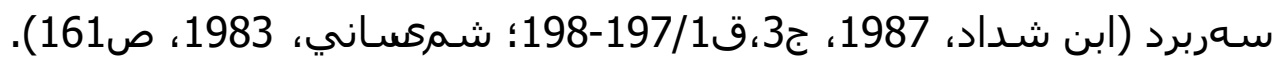

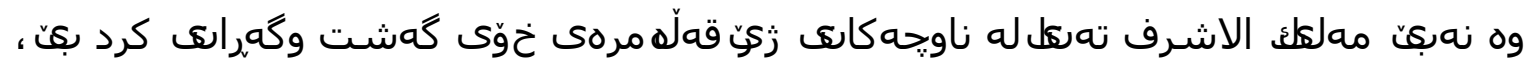

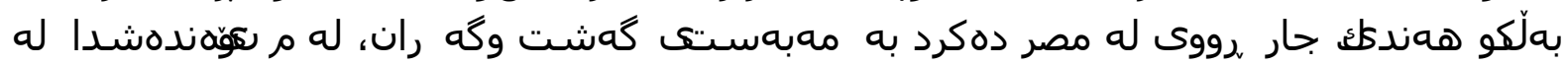

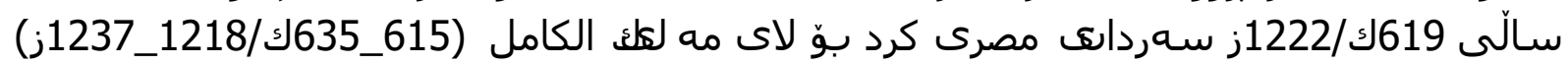

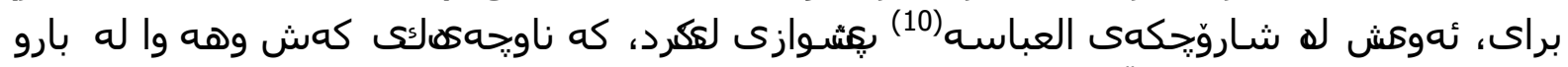

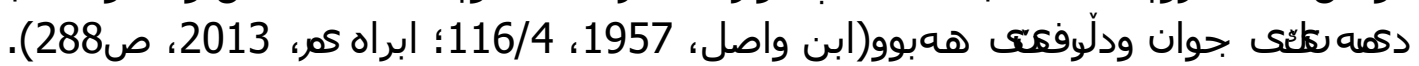

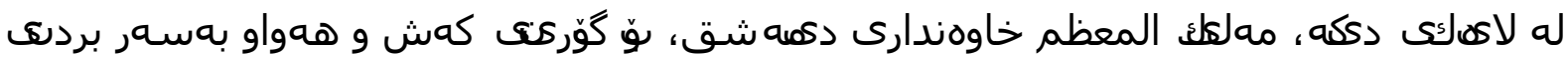

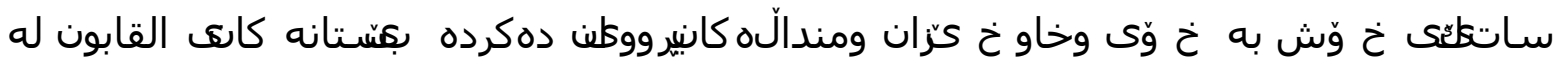

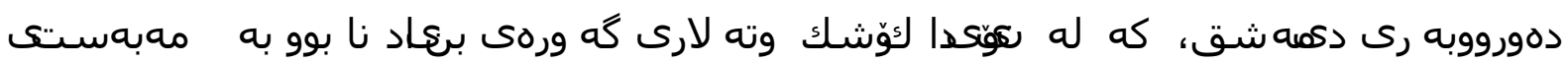

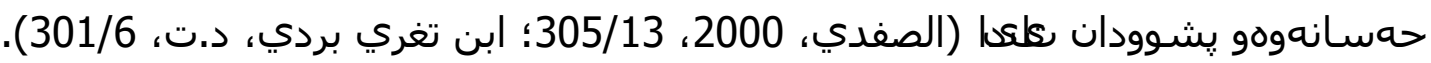

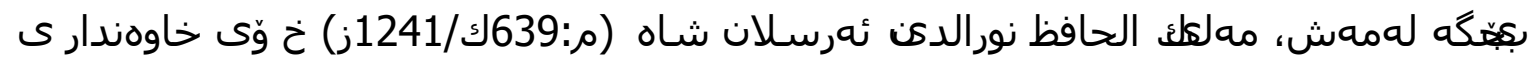

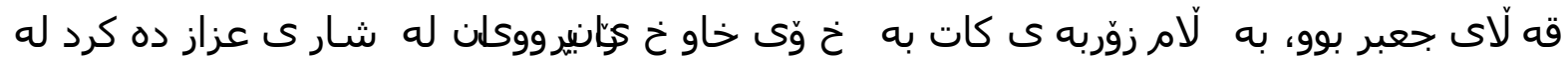

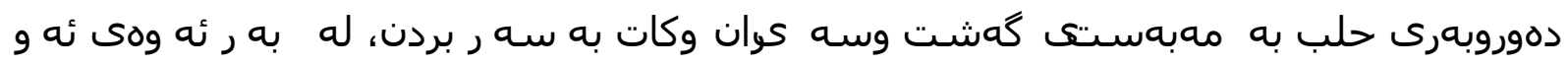

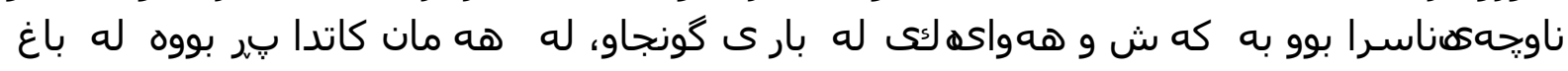

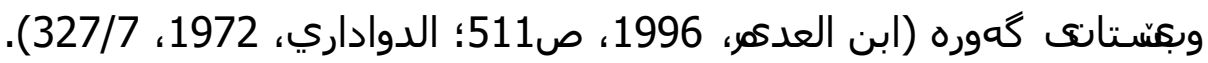

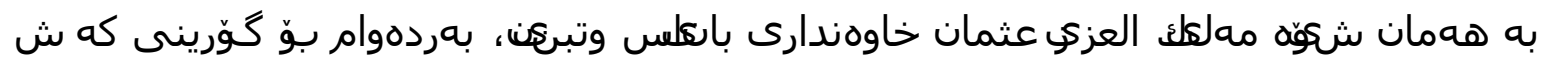

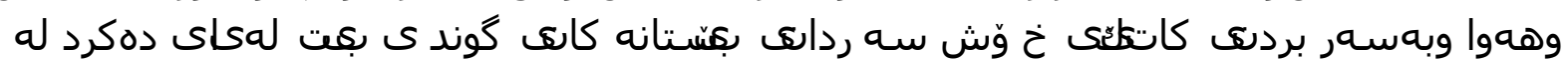

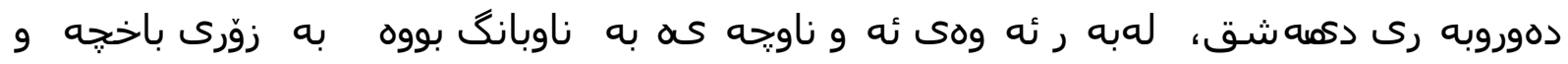

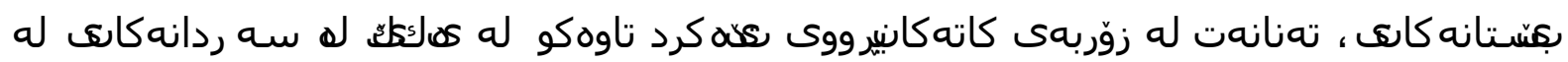

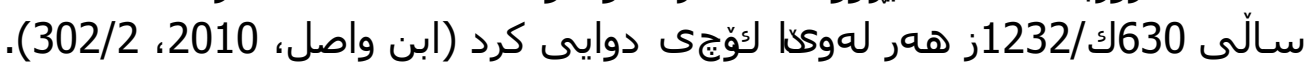

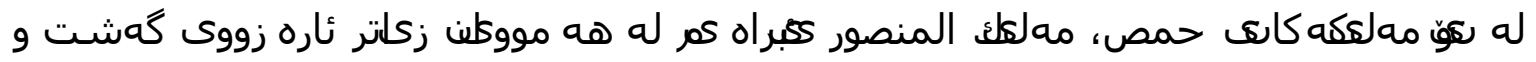

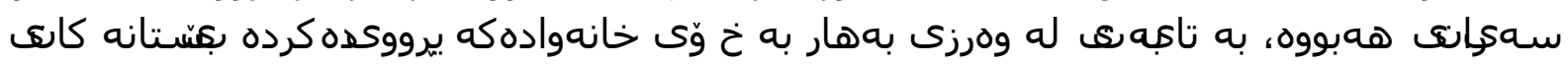

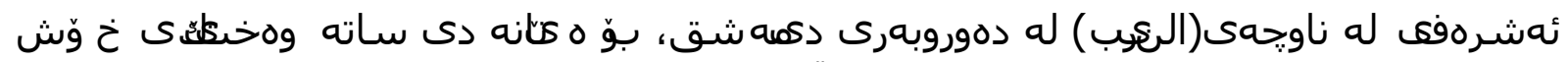

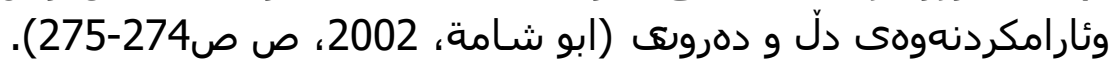

له لاكه كى دككه ش، نه وهكار تقى الد كن عمر ئه وانه خ خاوهنداركه كى حماكلن كردووه

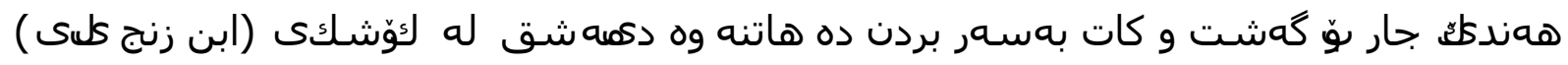

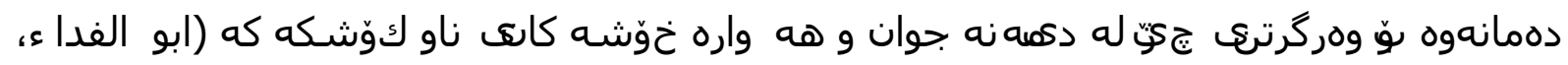
.). 158/3، 1999 


\section{دووم / دالكشتنهكان كات بهسهر بردن}

سـبارهت به دارششتنه كاه كات بهسهر بردن زكلتر ئه و ج وّره داركشتانه ن كه مaلككه كارى

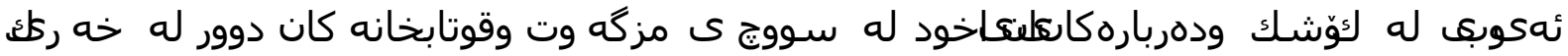

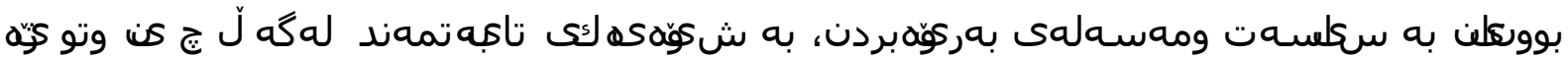

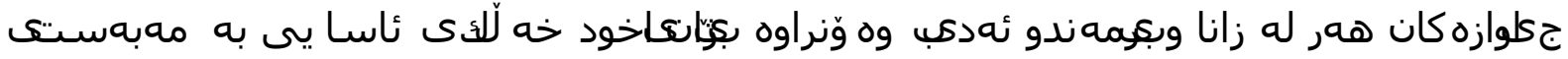

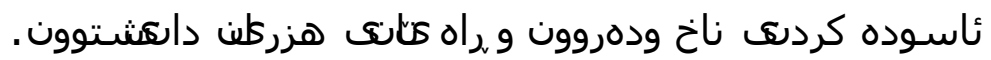

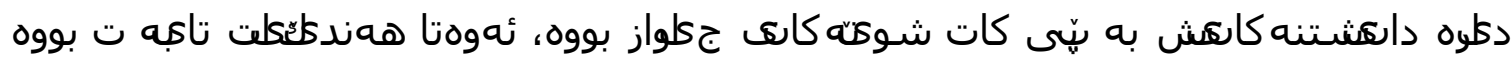

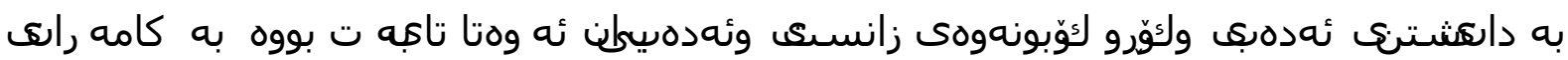

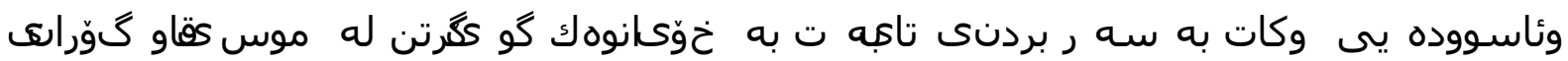

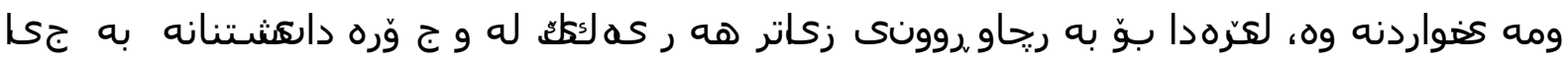

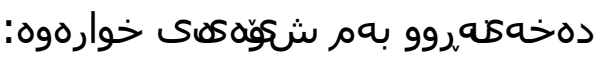

\section{1_ دالكشتى ئهدهبى وكَّرو لكوّبونهومى زانسـى}

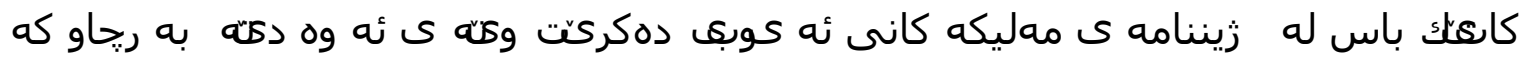

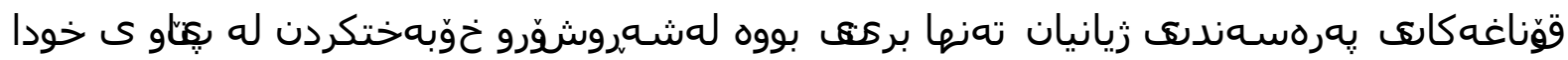

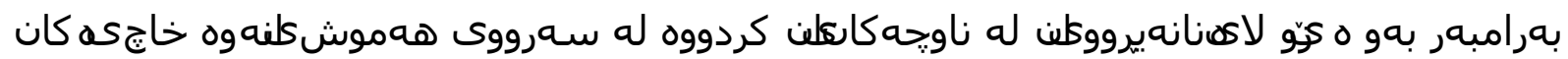

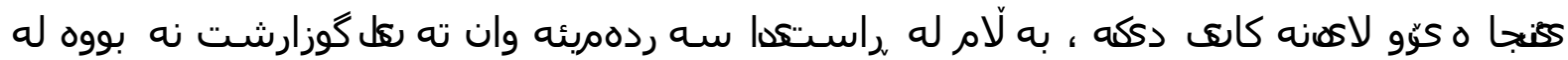

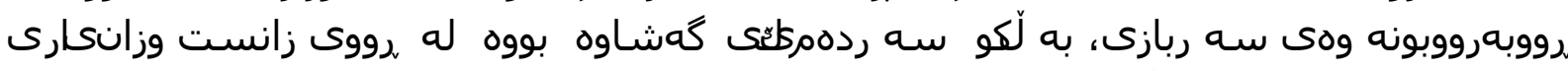

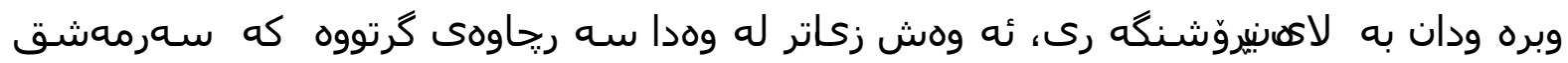

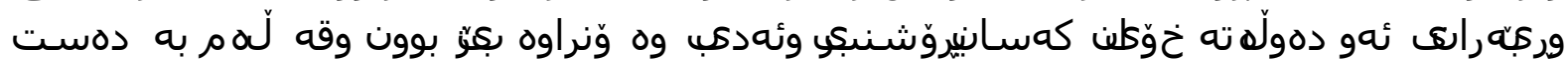

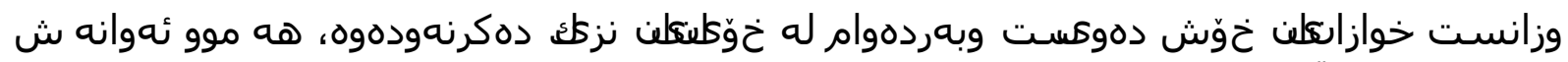

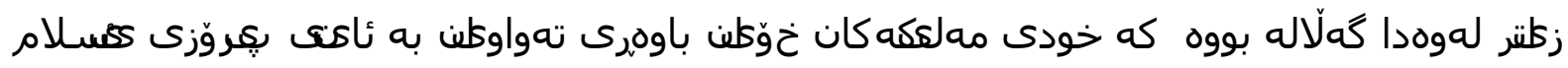

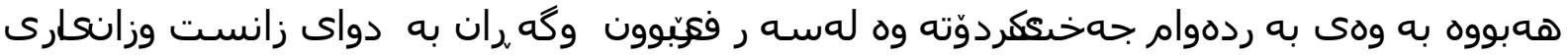

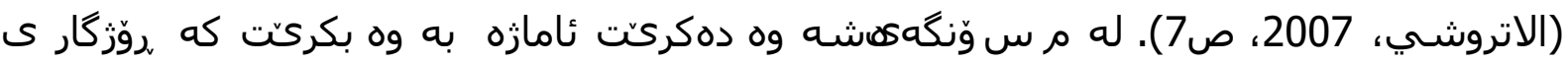

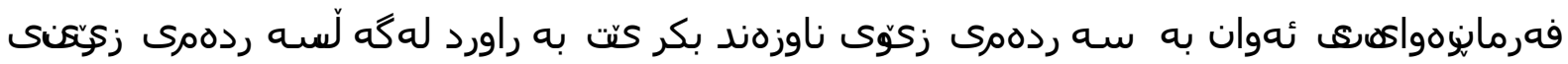

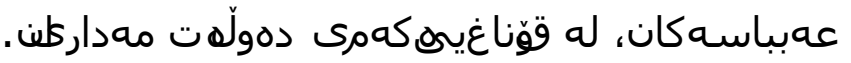

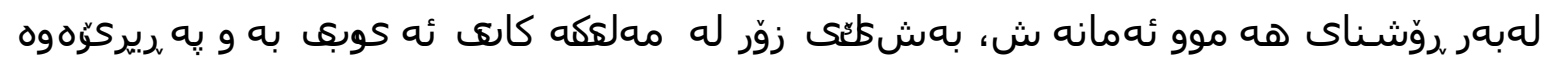

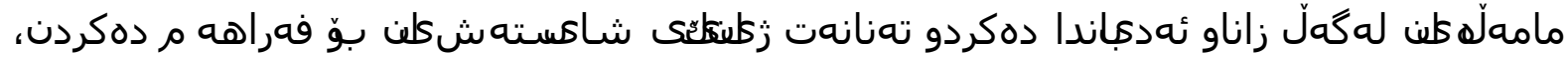

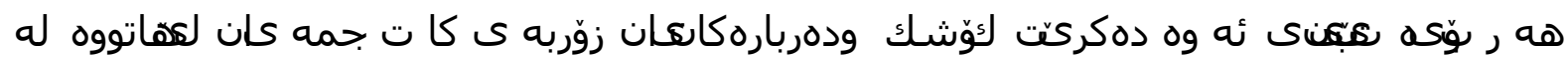

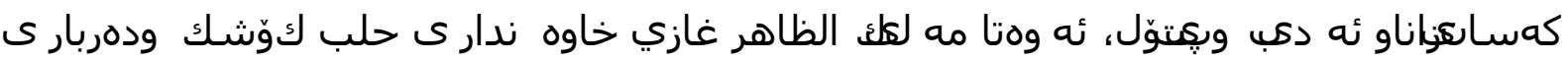

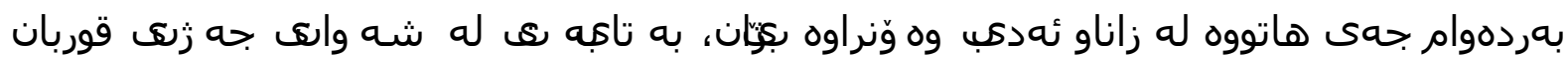

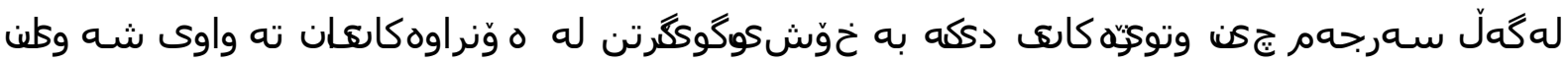

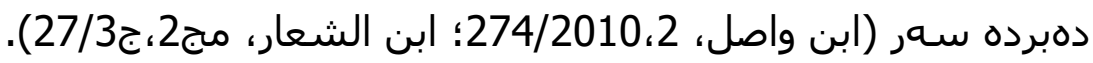

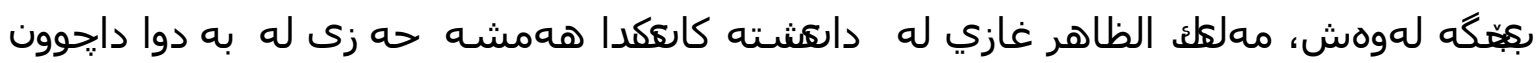

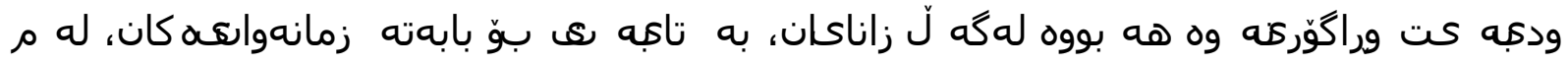

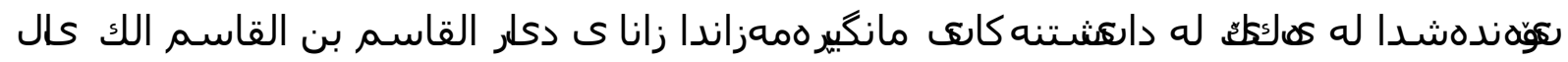

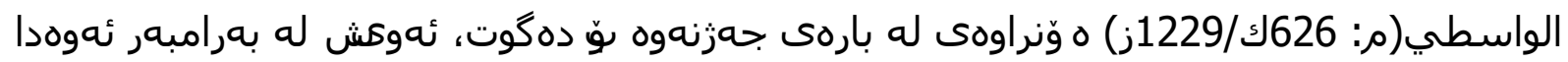




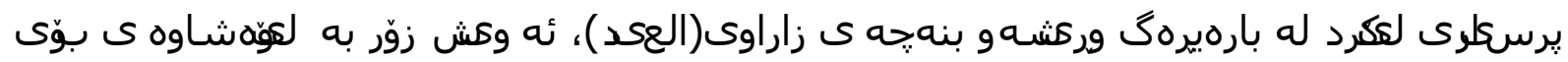

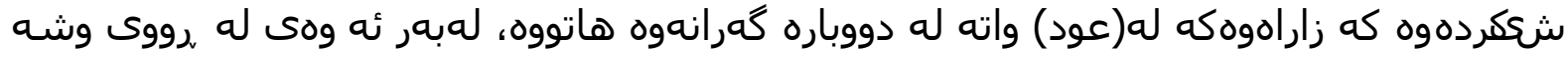

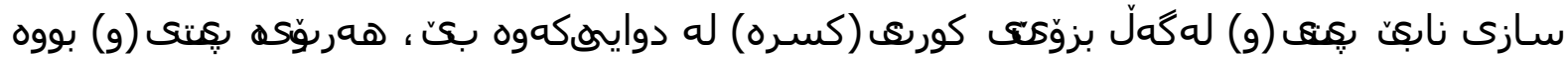

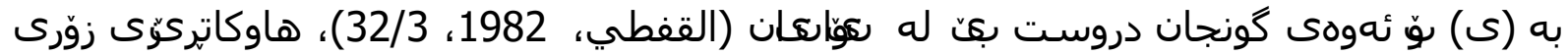

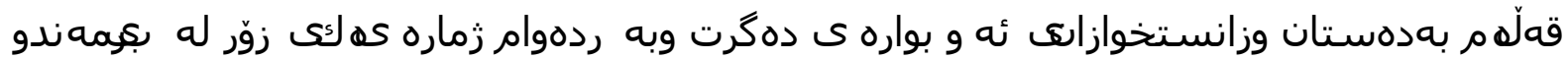

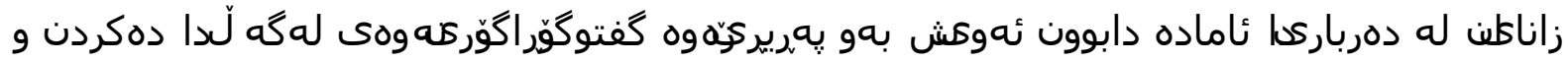

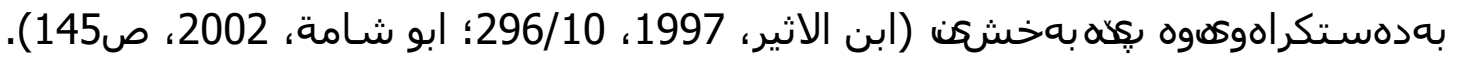

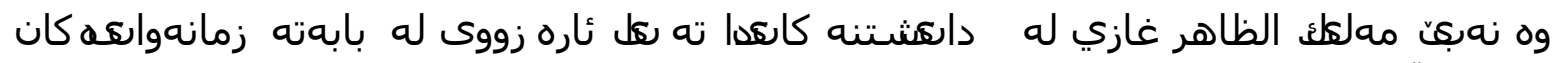

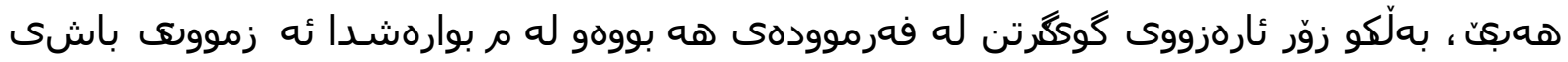

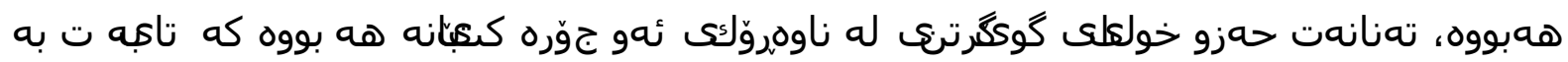

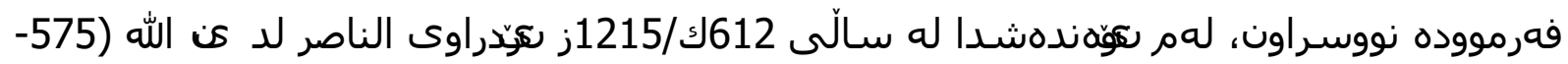

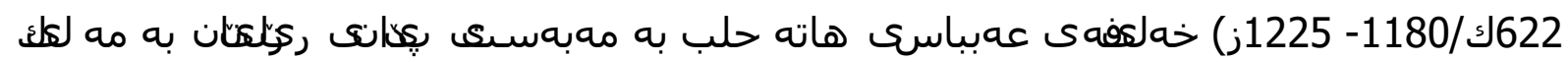

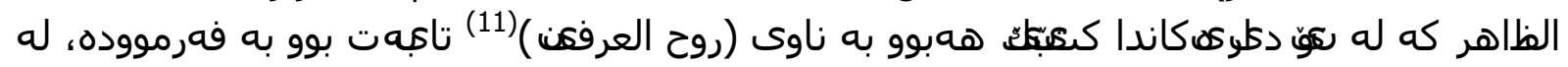

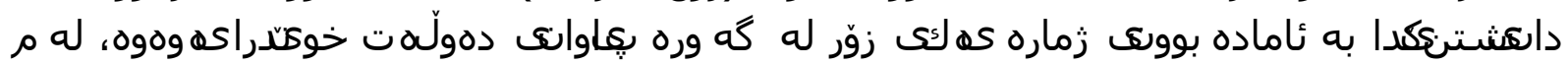

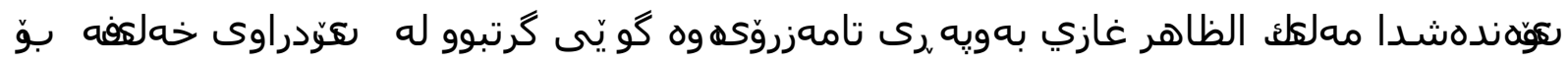

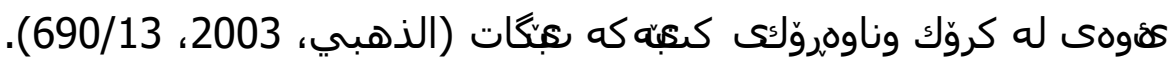

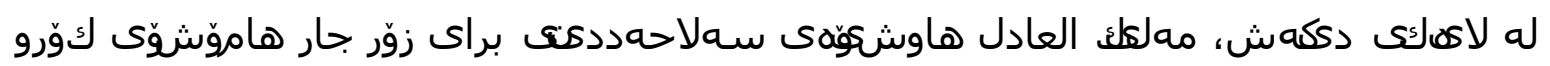

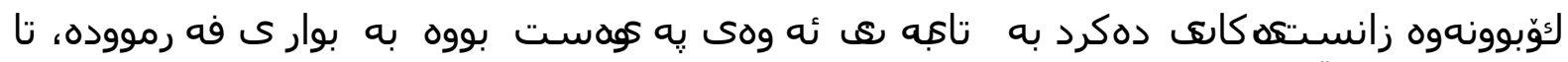

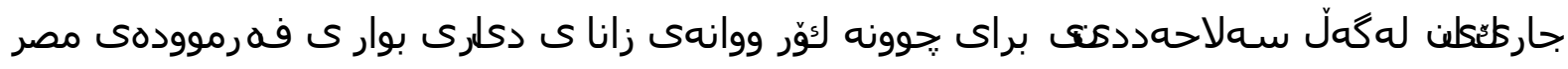

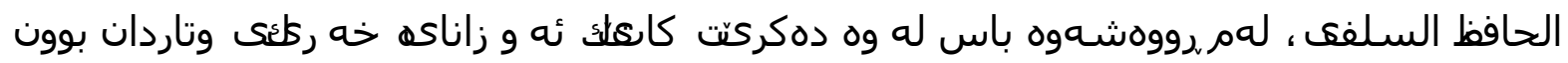

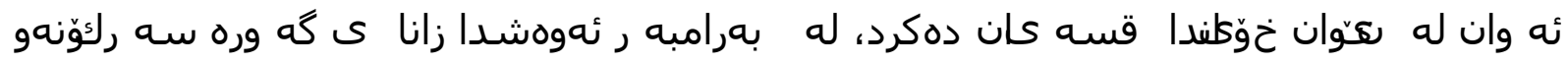

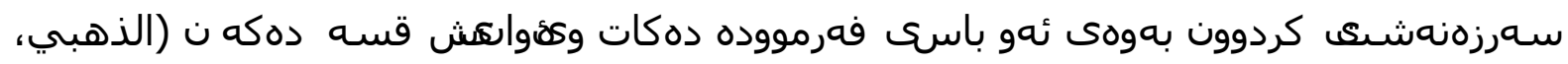

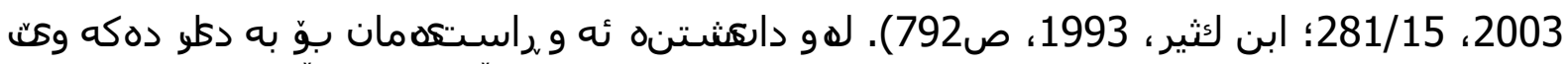

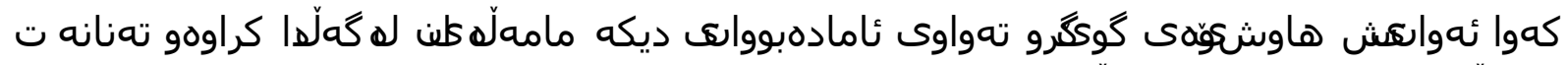

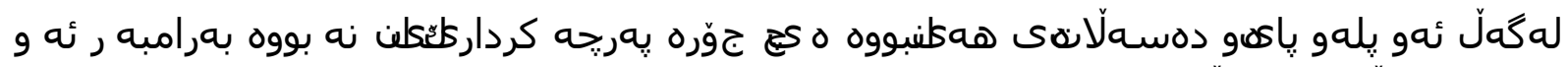

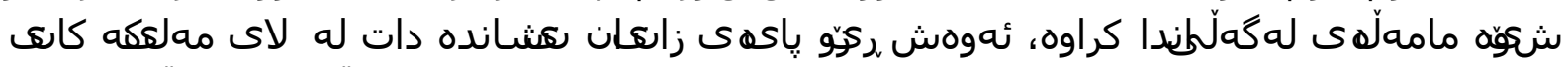

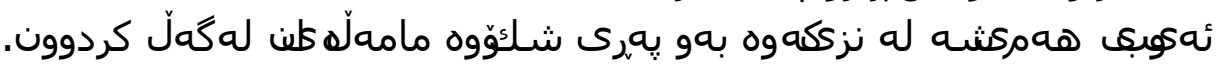

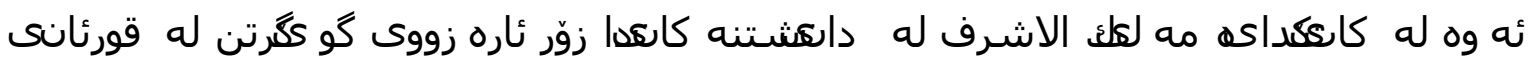

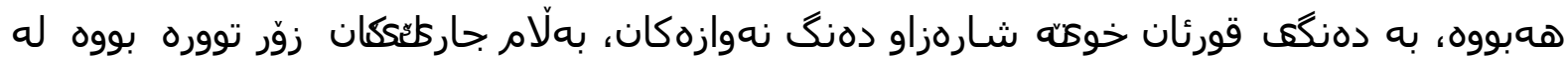

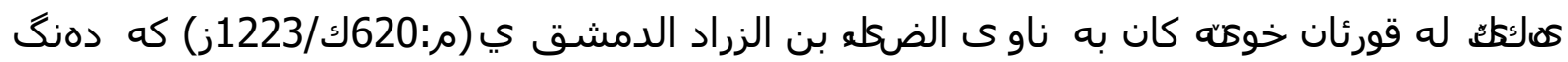

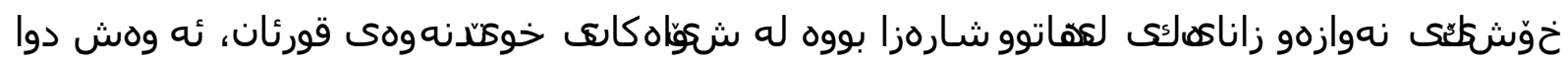

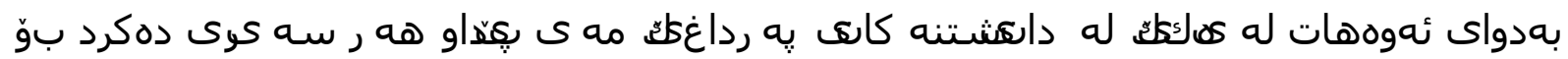

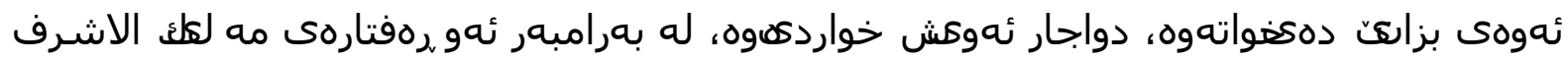

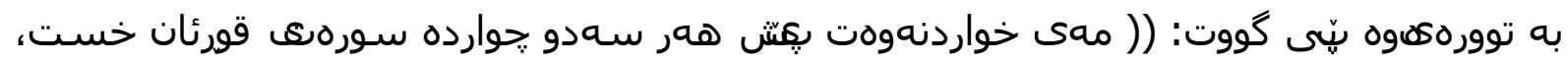

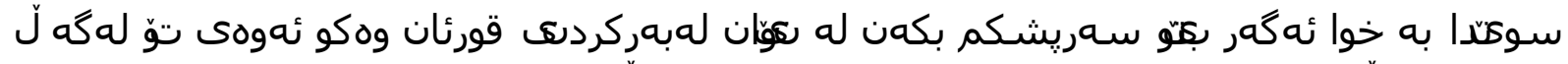

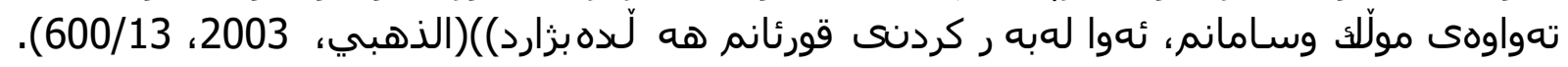

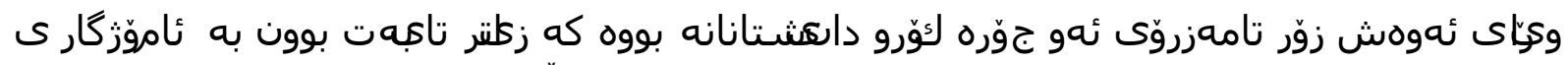

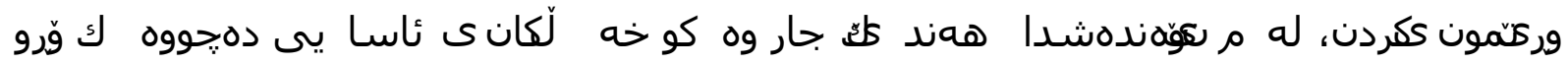

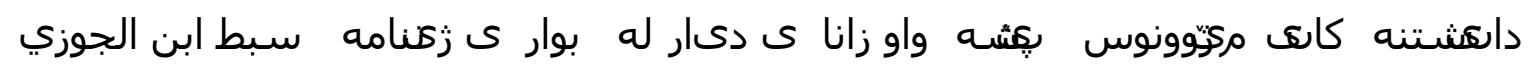

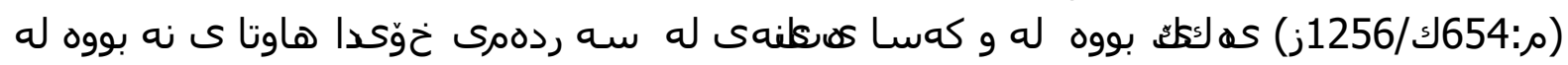




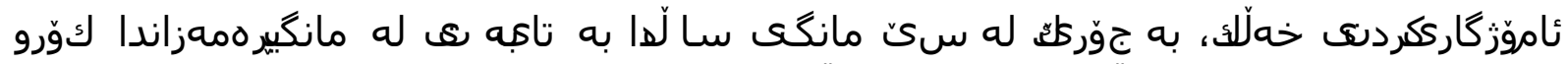

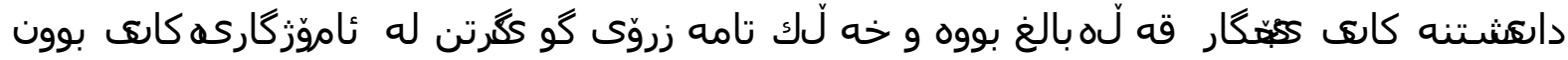

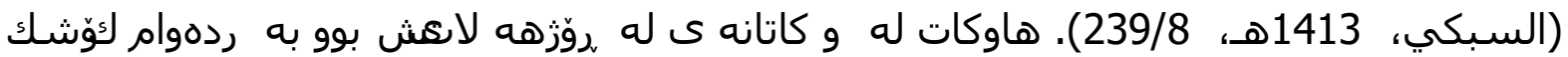

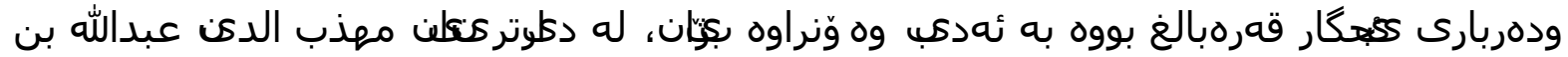

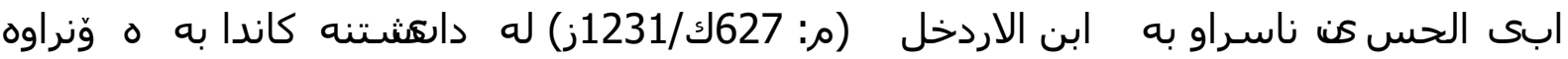

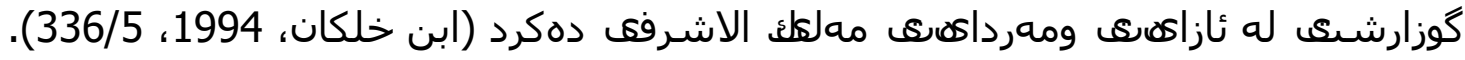

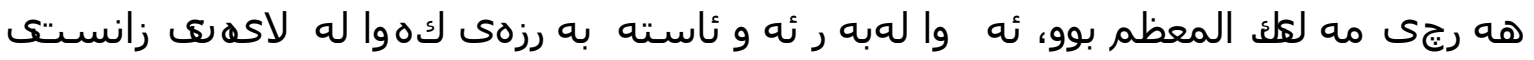

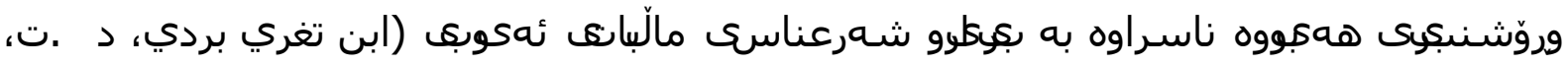

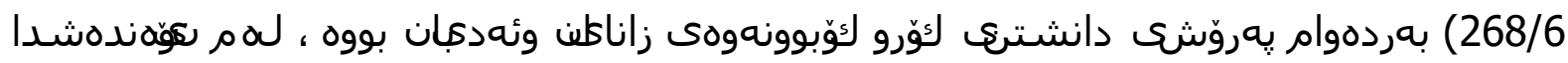

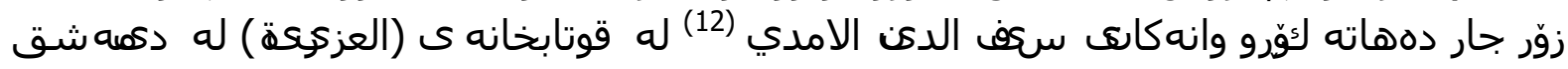

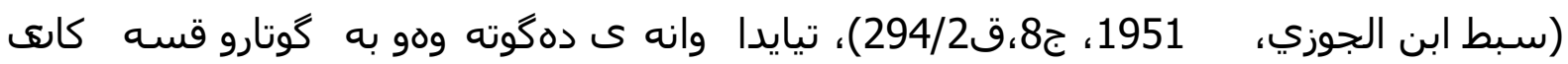

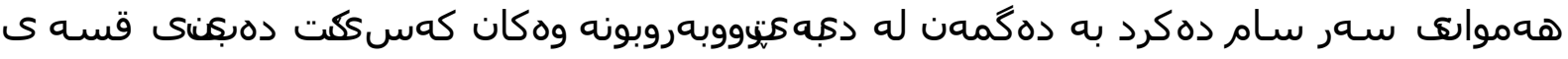

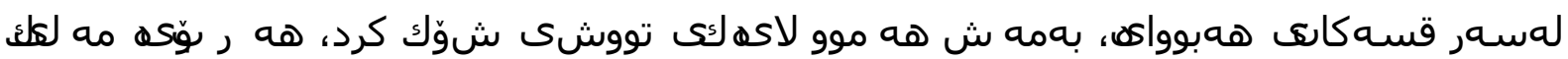

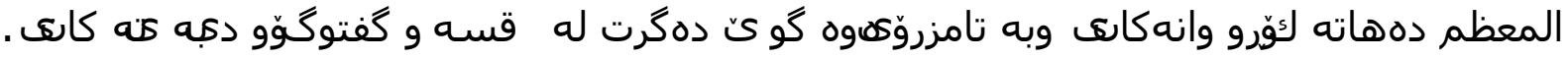

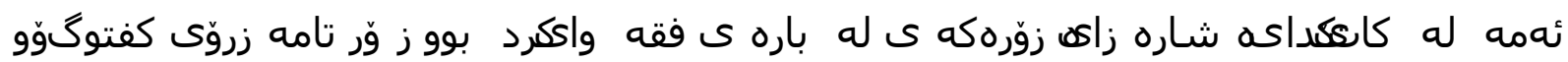

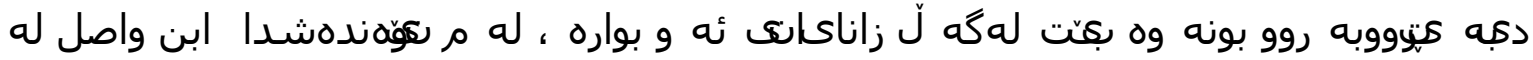

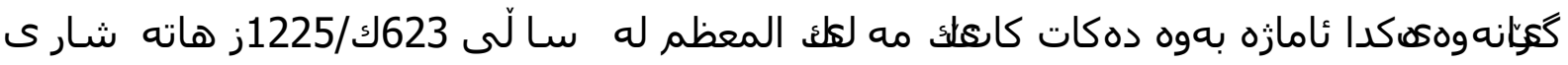

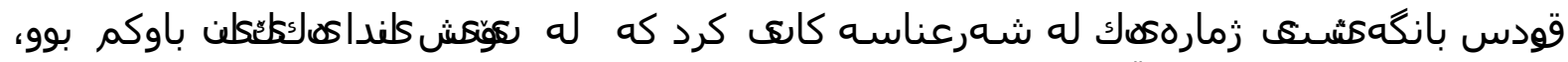

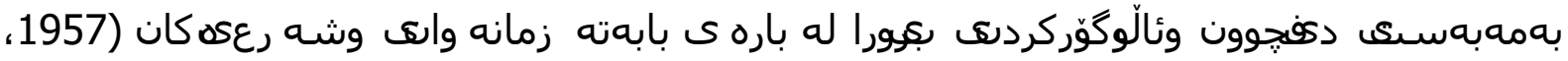
.$(213 / 3$

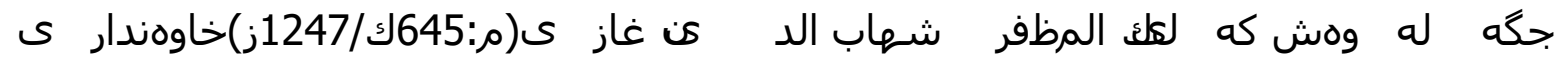

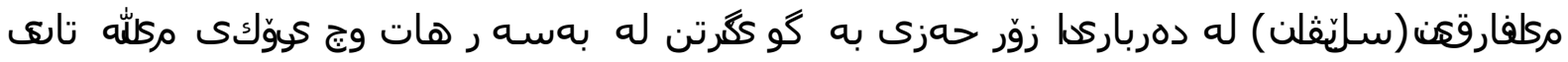

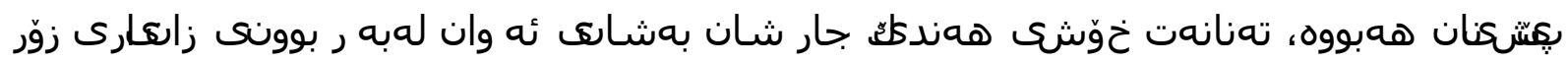

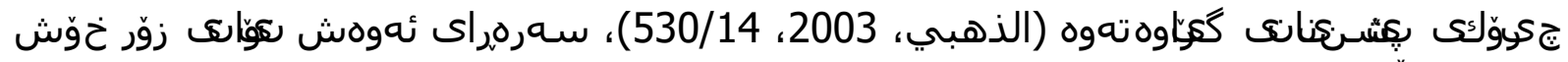

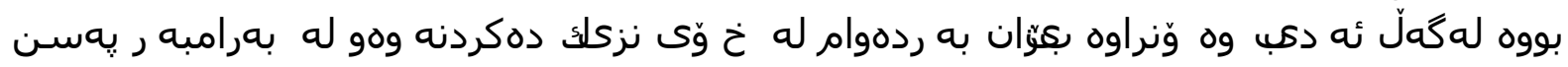

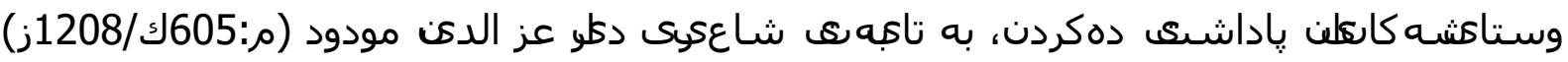

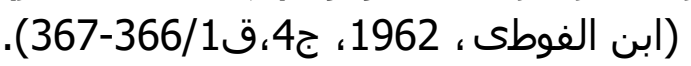

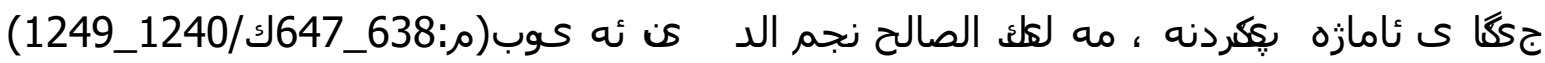

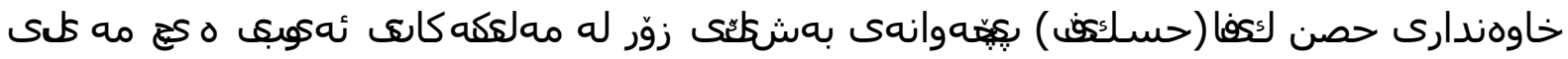

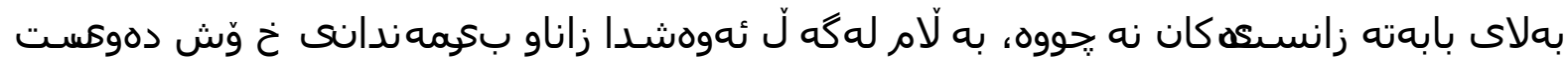

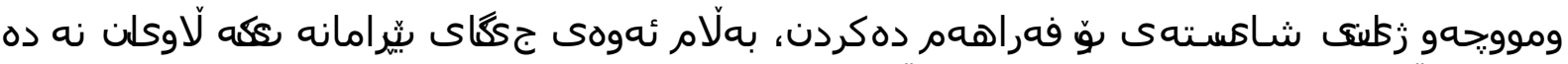

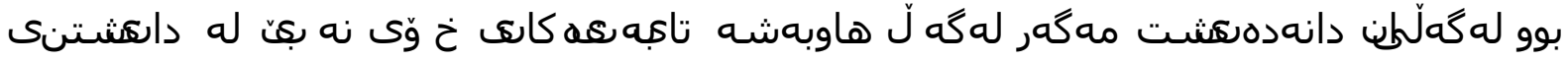

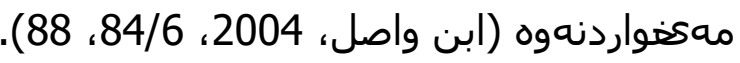

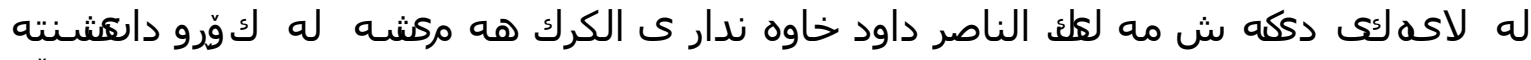

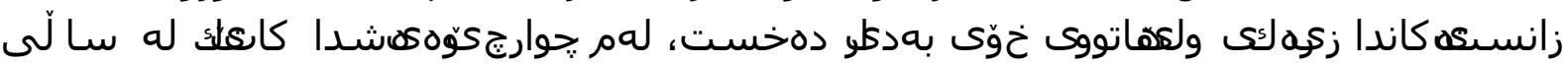

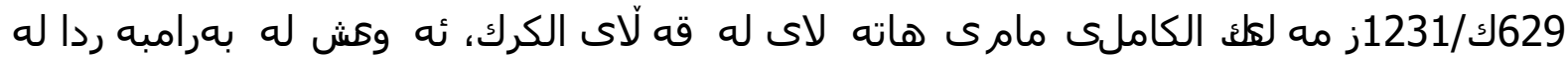

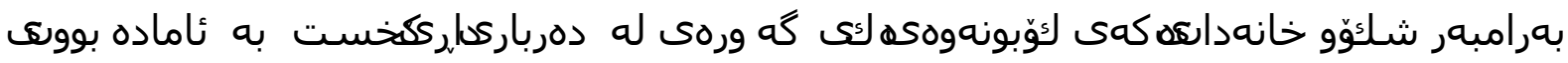

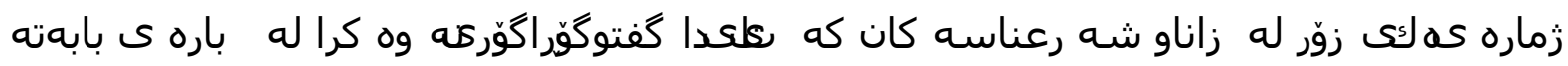

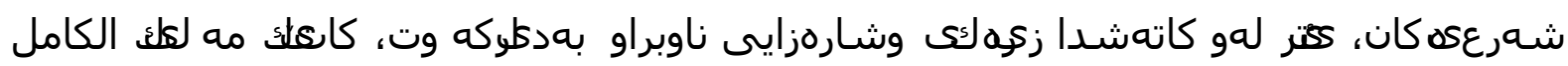




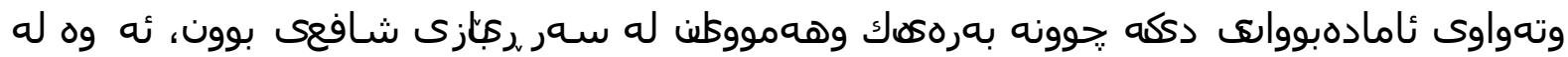

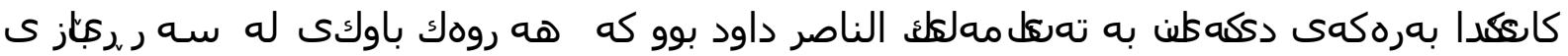

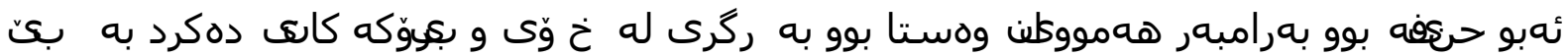

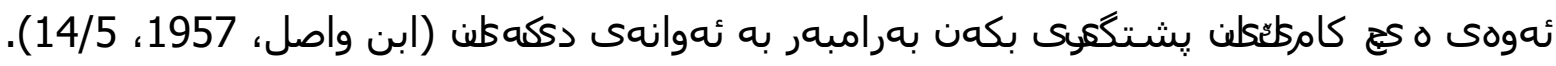

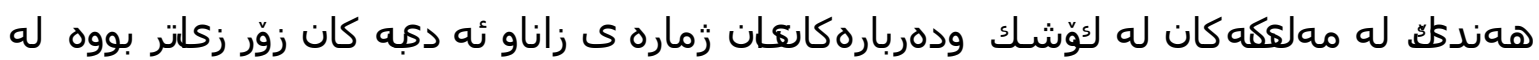

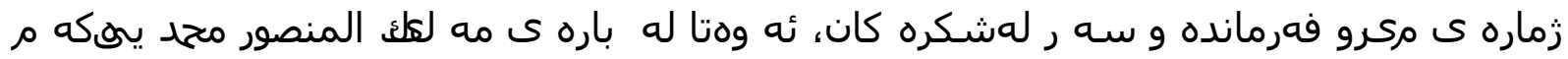

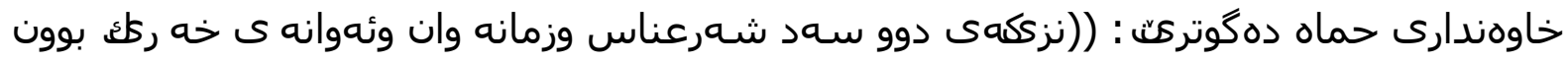

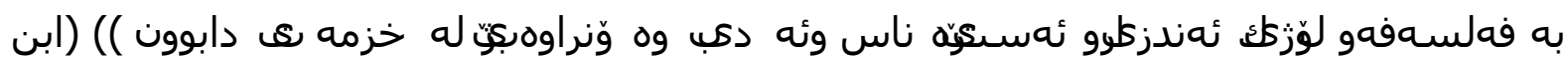
واصل، 1956، 79/4؛ الكتبي، خونه 1974 1974، 12/4).

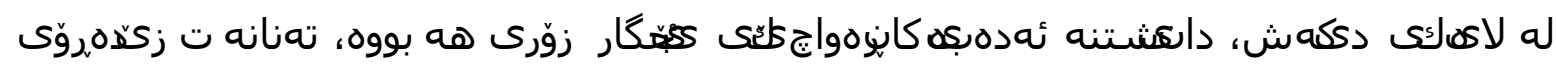

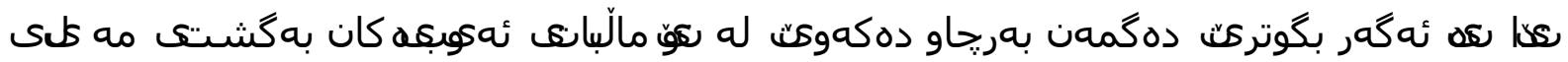

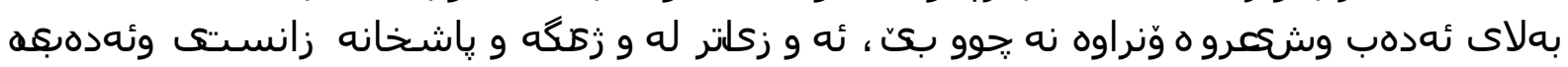

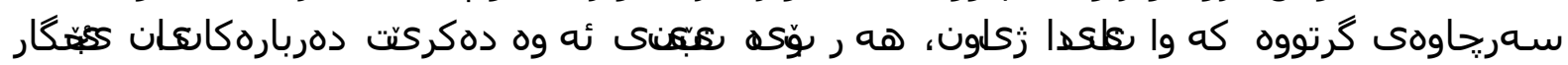

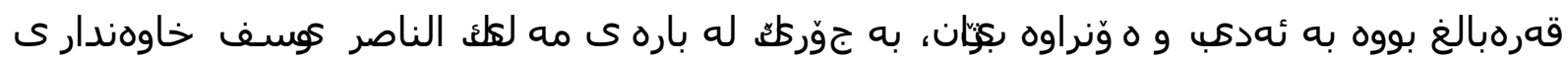

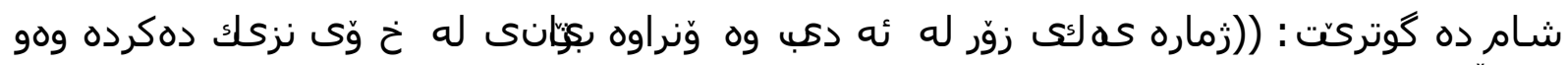

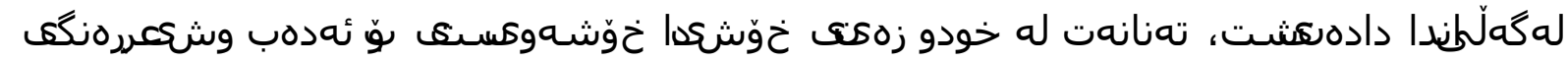

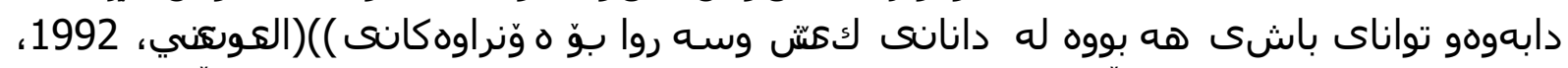

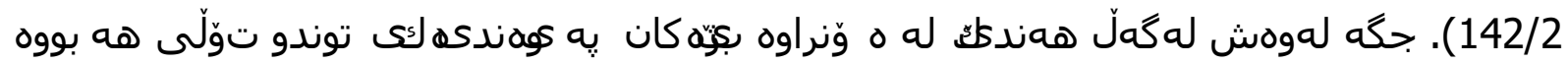

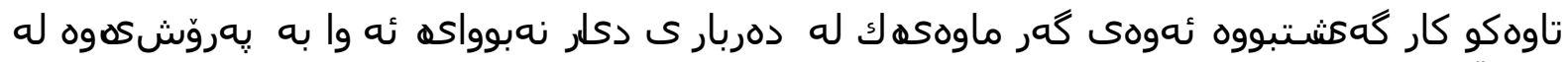

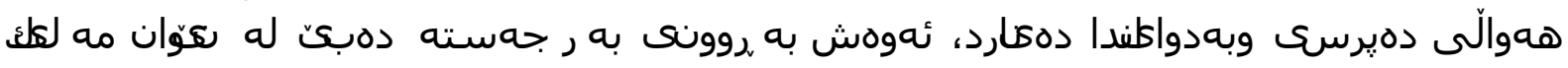

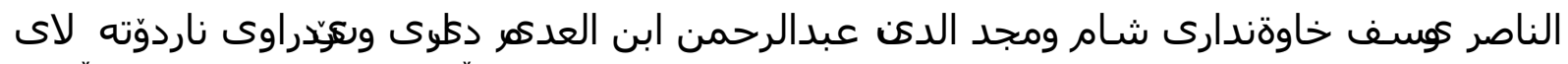

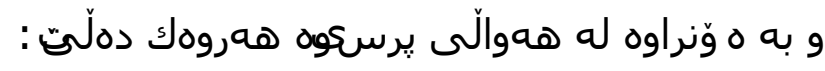

اقول لدمعى عن صارت بمهجى لقد خفت ان تبكف عكني الاقف

فقالت جفوري لا تجف فهض عبرى فبشراك قد اوف ى قم كص لعوسف (العورنني، 1992، .(312/3

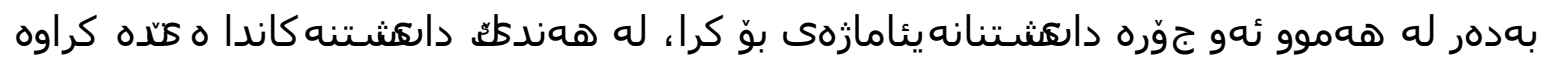

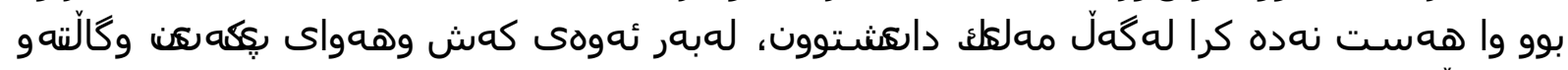

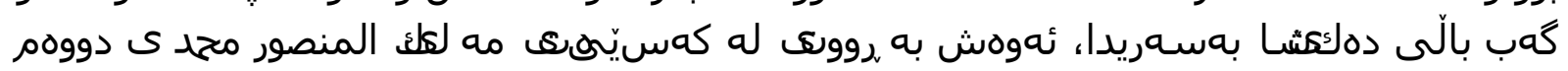

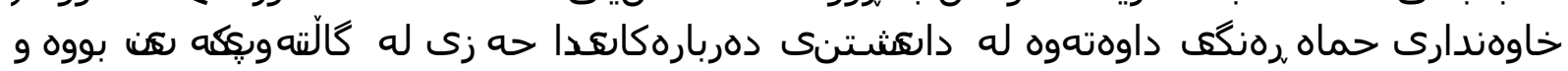

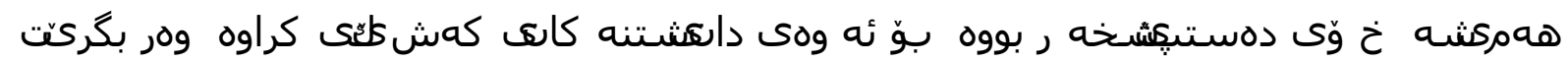
(الصفدي، (2000، 9/5).

\section{2}

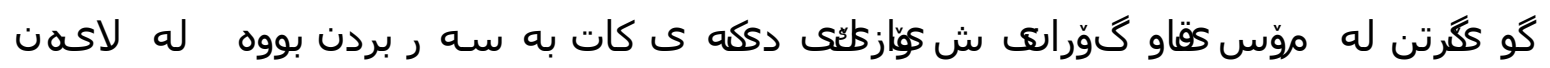

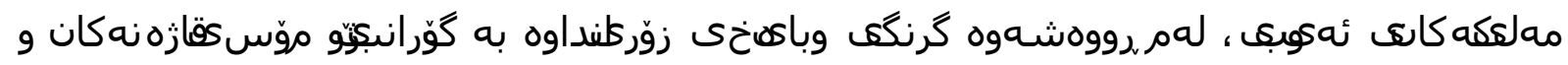

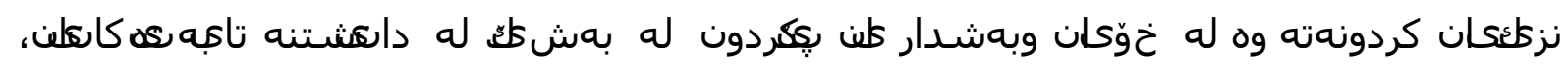

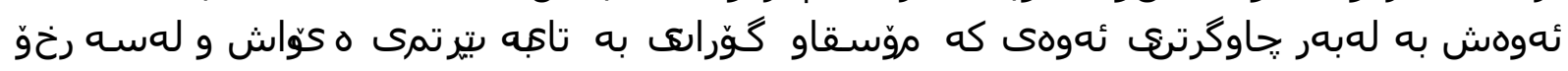




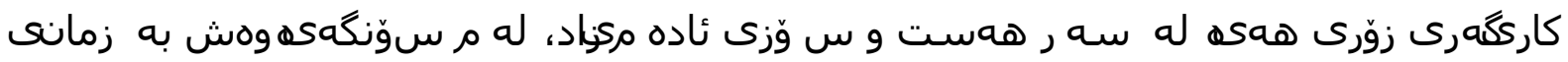

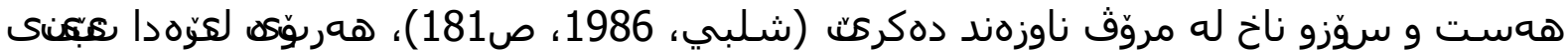

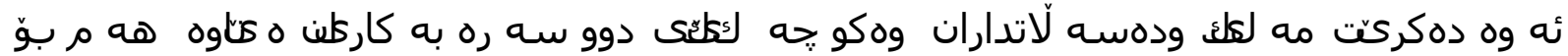

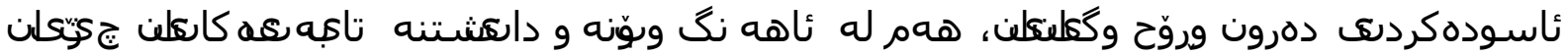

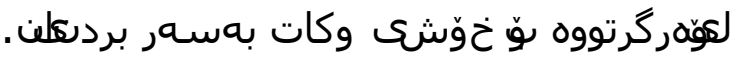

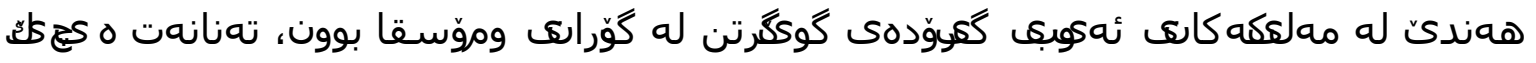

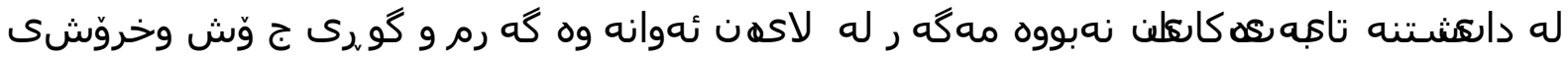

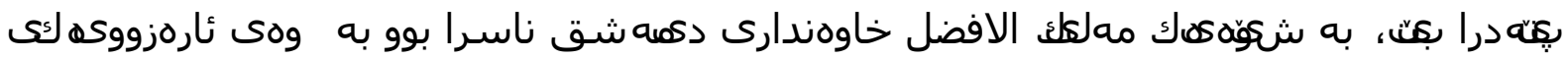

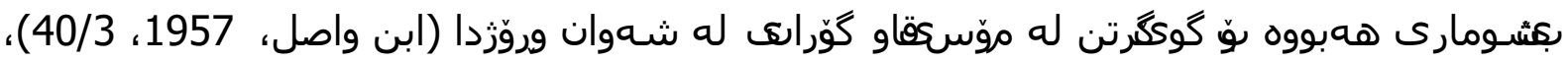

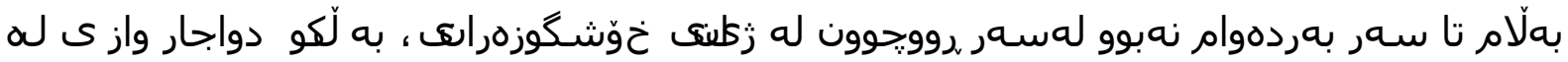

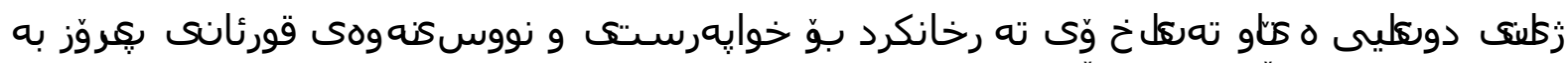

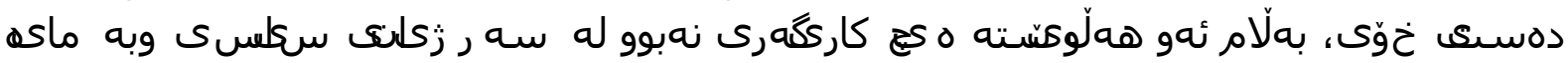

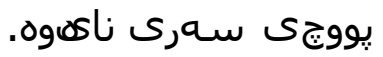

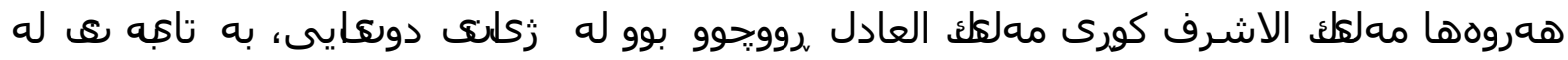

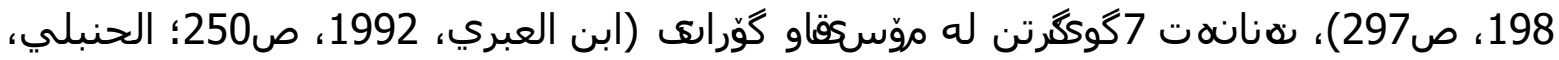

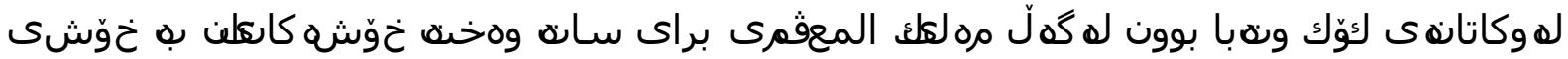

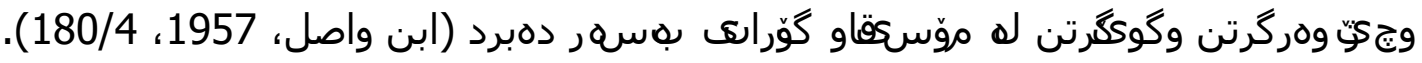

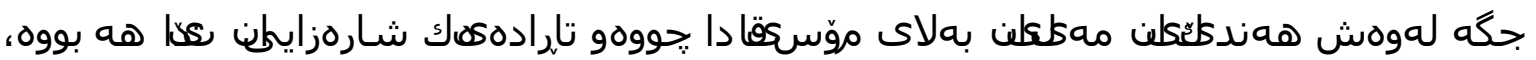

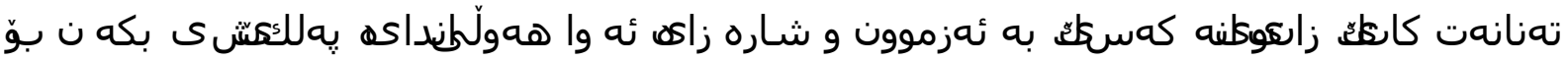

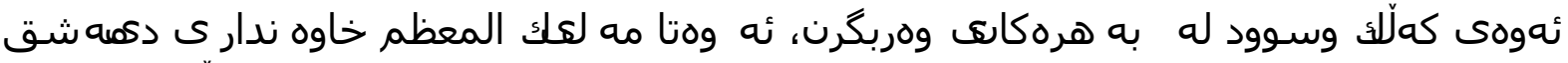

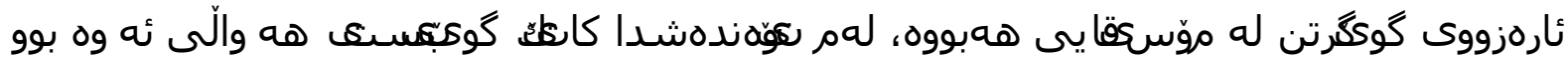

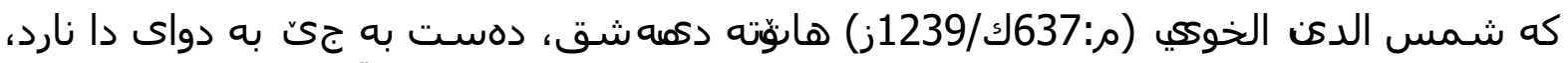

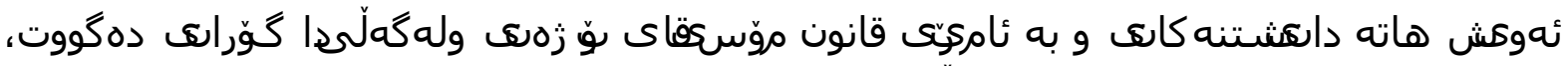

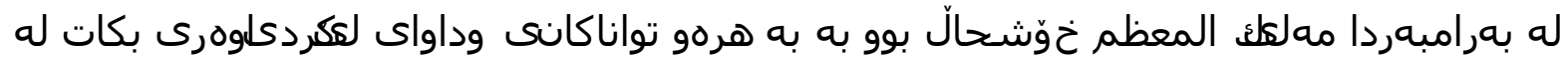
كات بهسهر بردرى شهوانهكار (النويري، 2004، 177/29).

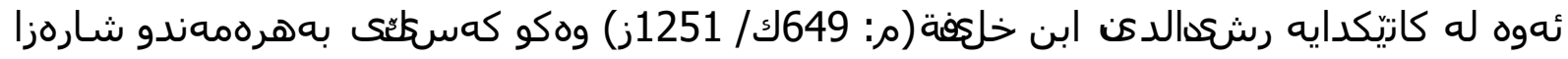

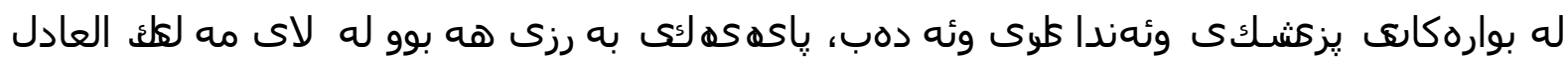

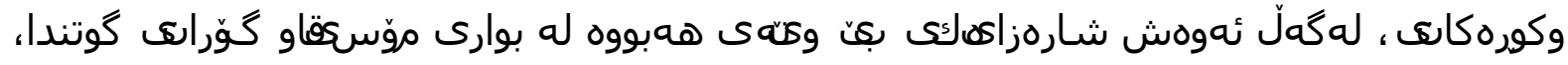

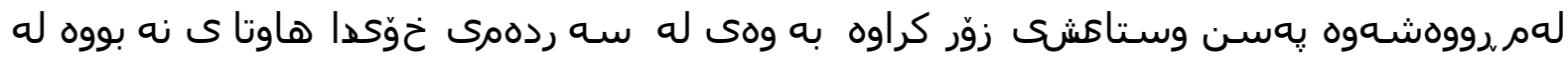

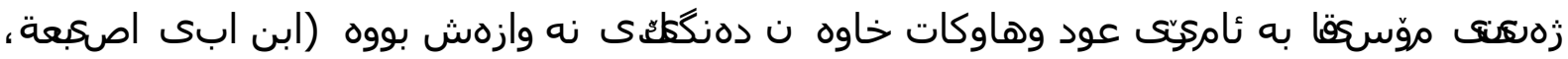

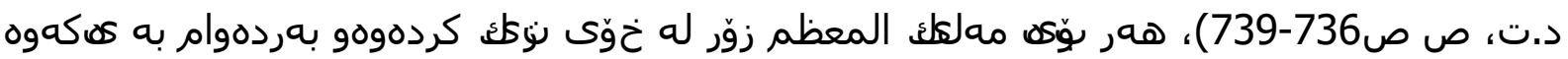

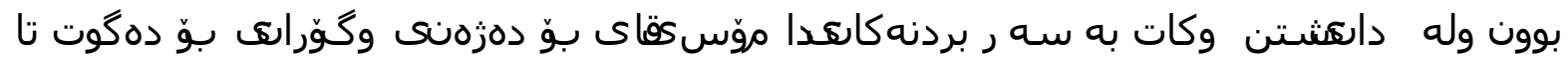

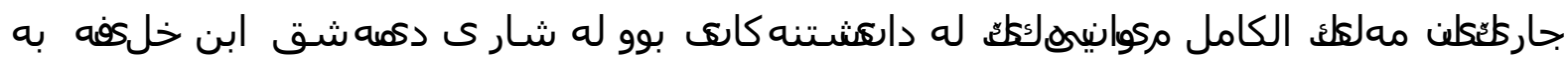

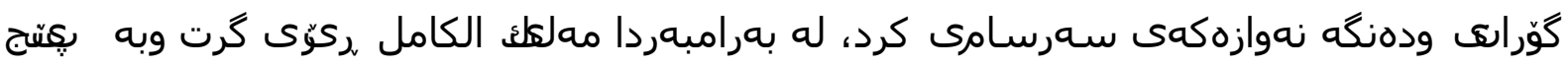

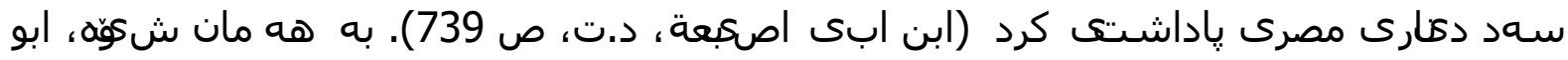

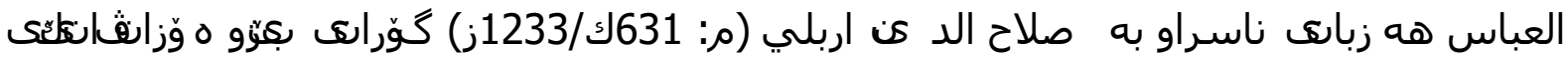

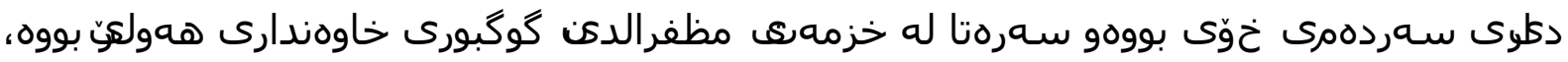

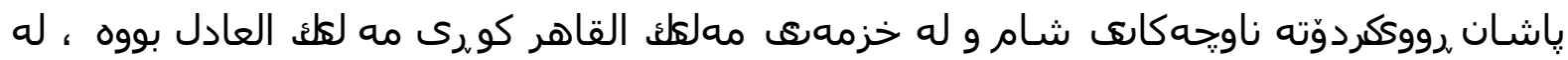

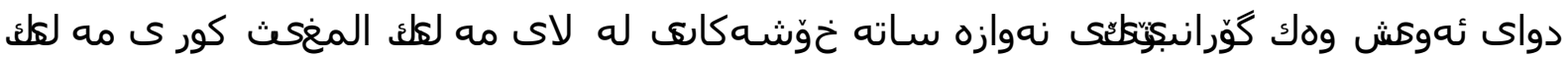


العادل بهسهر بردووه و لموهرى كردووه له كهشت وگهرانهكاردا، دواى هه موو ئهوانه ش جوّته

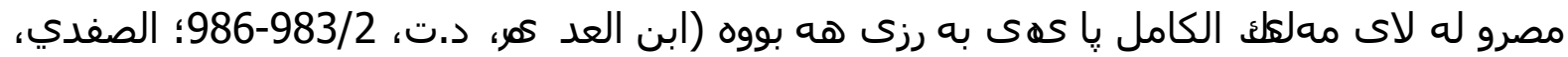

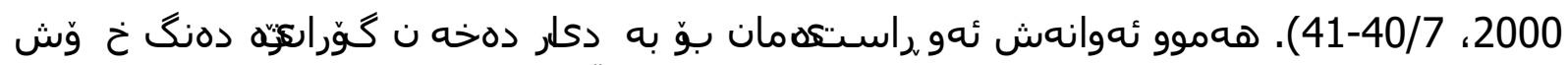

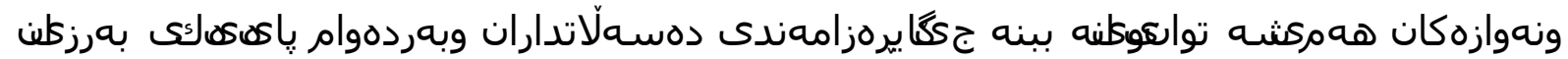
همبووه له لاكلن.

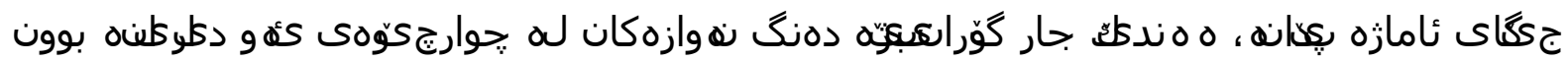

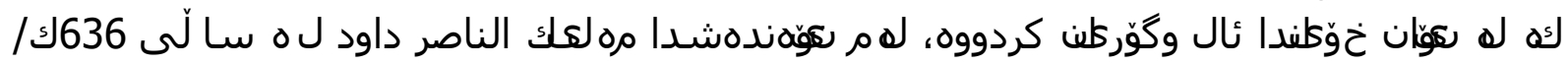

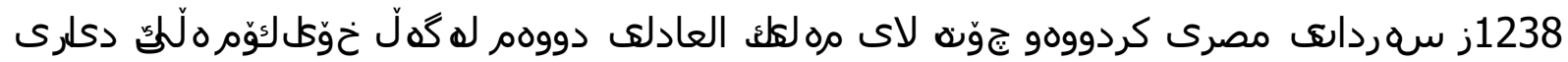

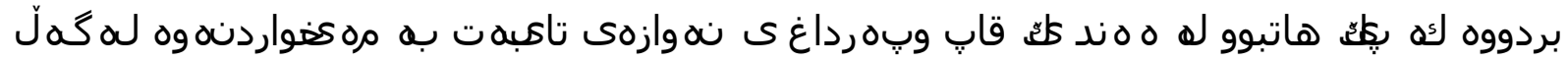

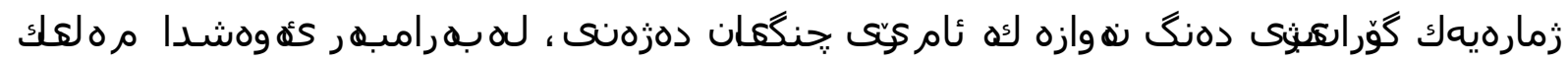

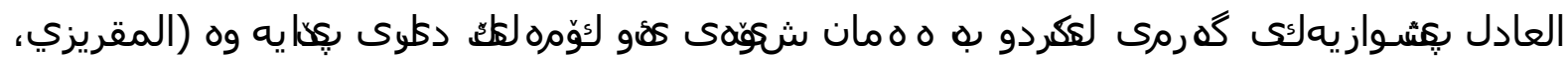
.389/1، 1997

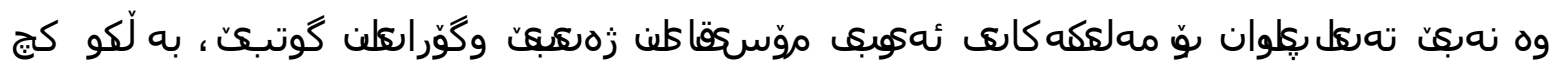

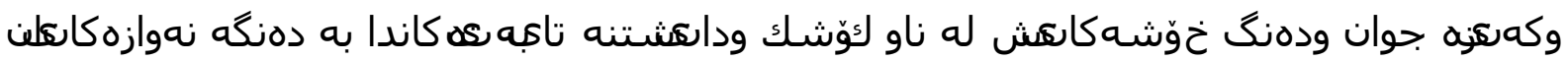

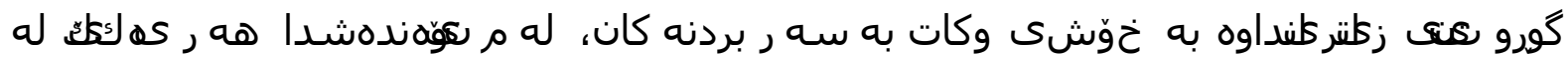

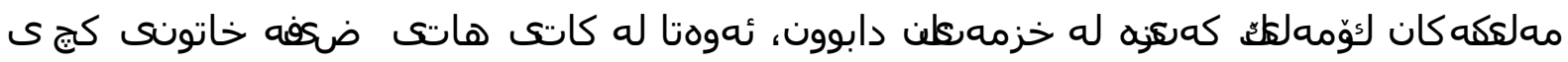

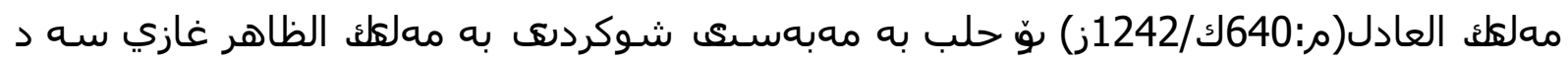

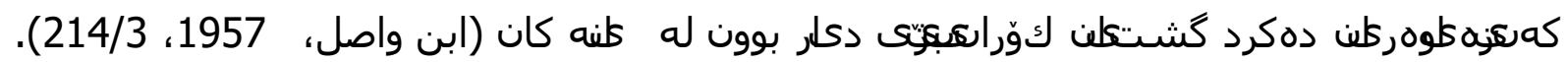

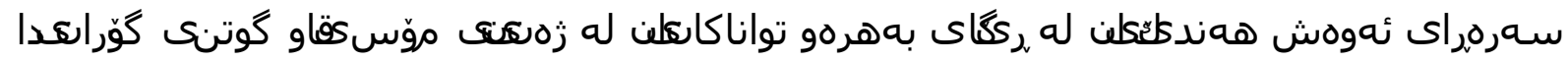

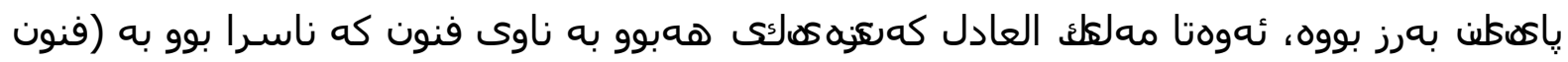

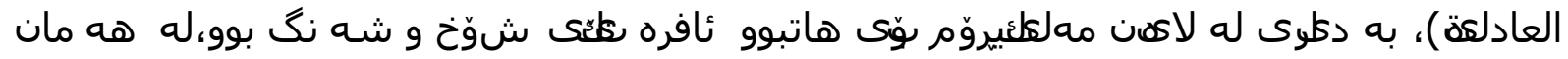

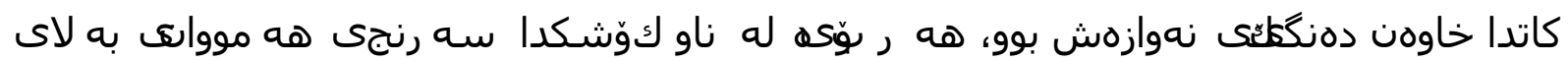

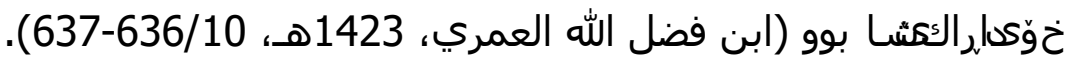

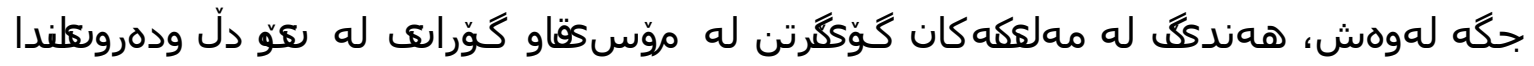

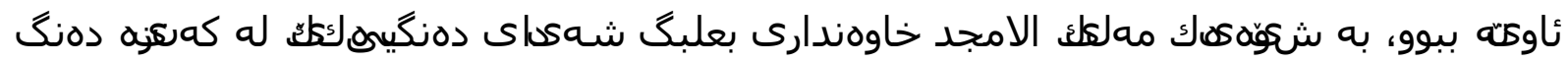

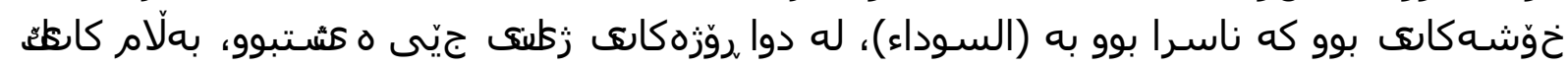

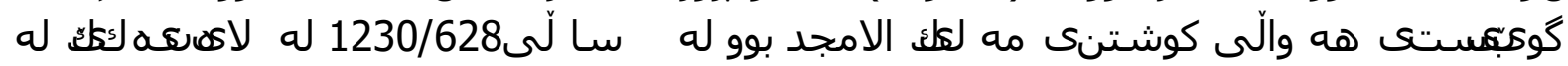

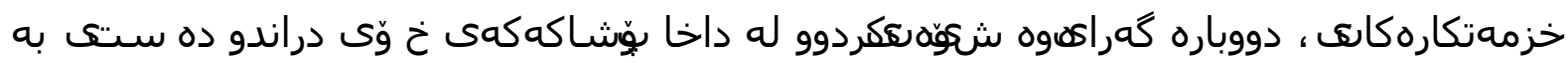

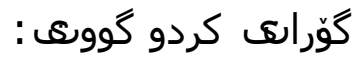

وقد كنت ارجو طكفبا ان كلم بع فلا طكفبا وافي ولا اجتمع الشمل ل وعندى من تعطفها شغ

فلما احسـست بالمات تعطفت علي

اتت وحكل الموت بكني وبكنهاوجاءت بوصل حكن لا كفع الوصل(مؤلف مجهول، 2010، ص386)

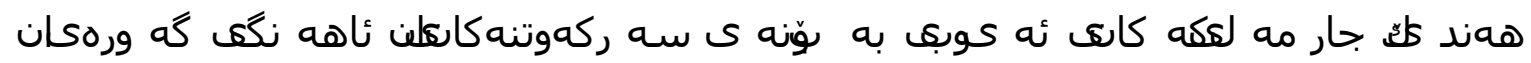

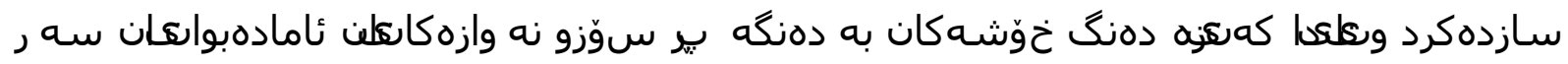

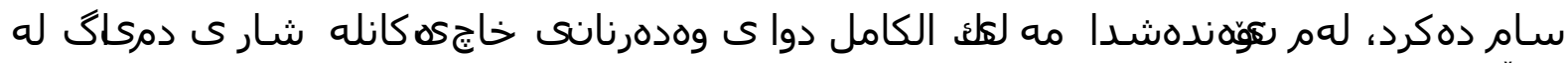

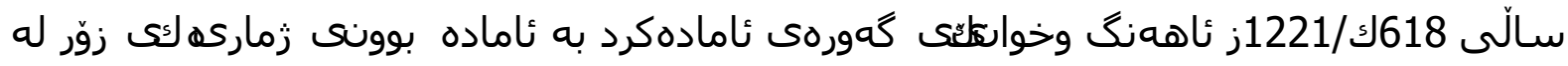

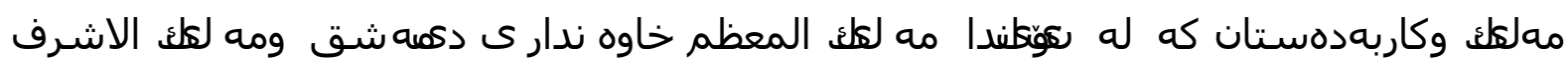




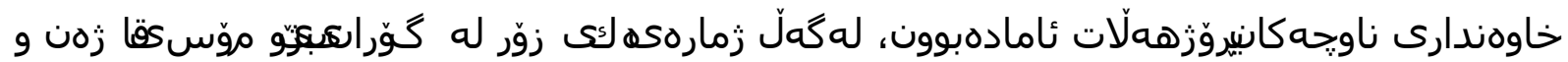

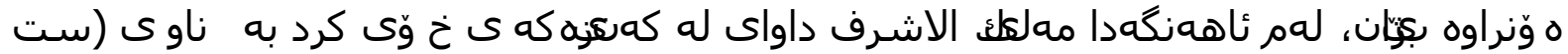

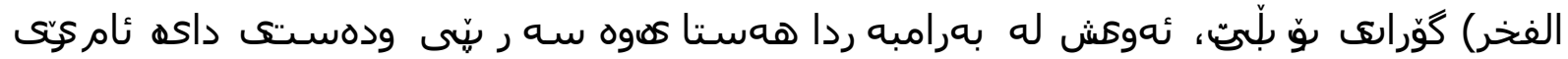

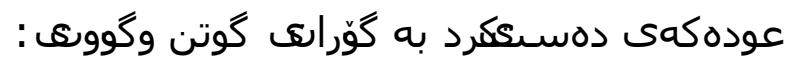

وجاء الع مــــصر لكفسـد في الارض

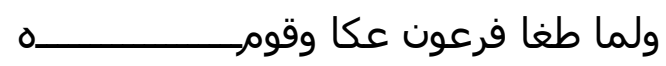

فأغرقهم فى العم بعضا على بعض ارى نحوهم موسى وفيهذ العصا

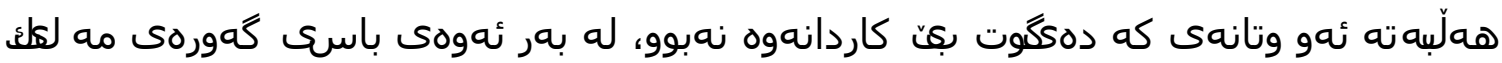

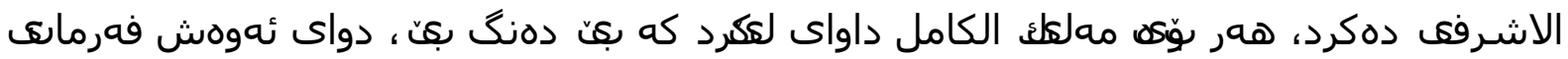

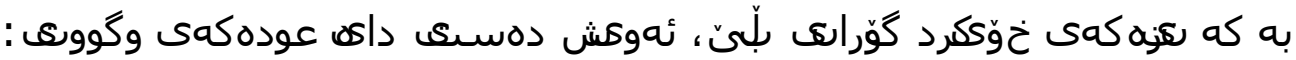

لما قد جرى فه وقتنا وتجدوا

الكأهل دهن الكفر قوموا لتنضرو

وموسى جمكعائصرون مجحدا

أعباد عكسى ان عكسى وقومه

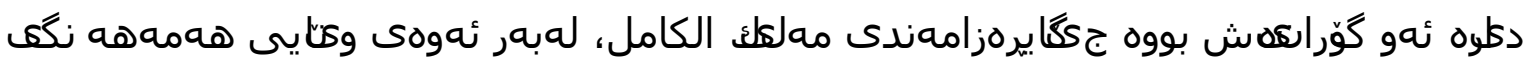

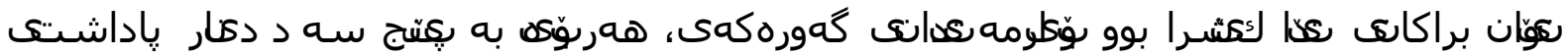

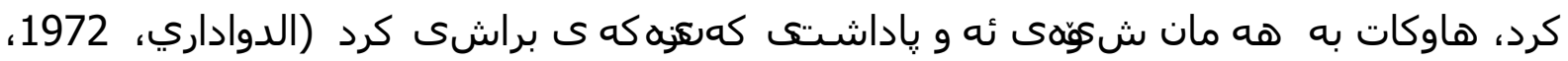

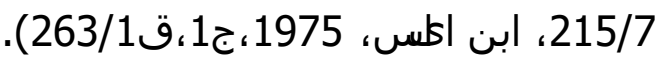

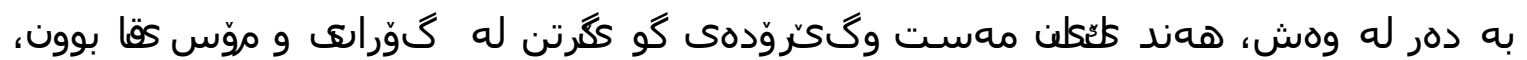

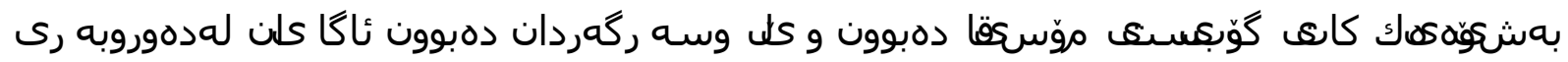

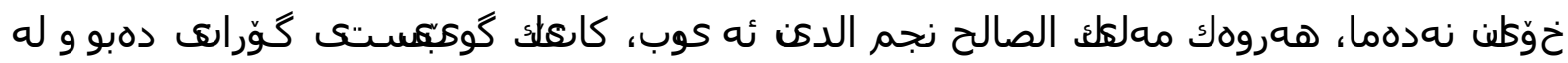

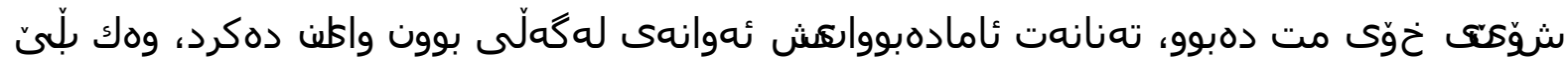

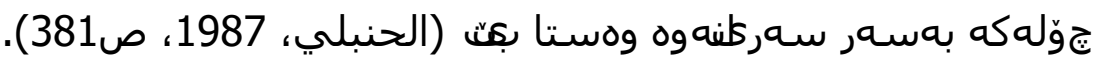

\section{3_ دالكشترى مaكنواردنهوه}

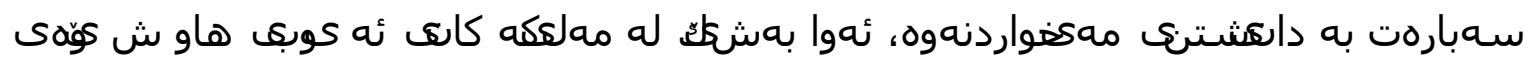

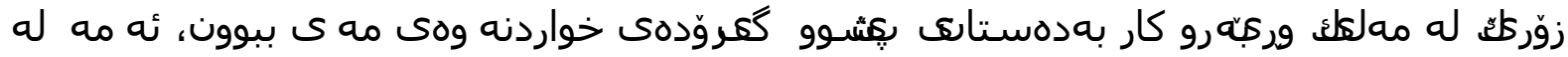

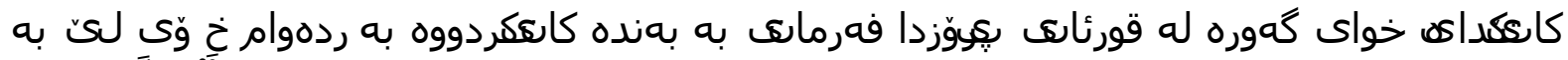

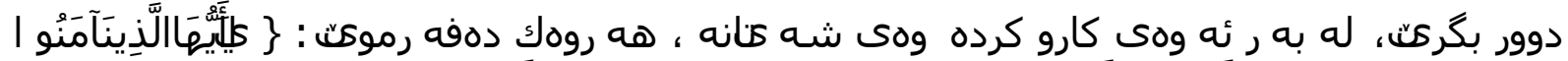

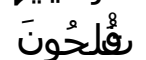

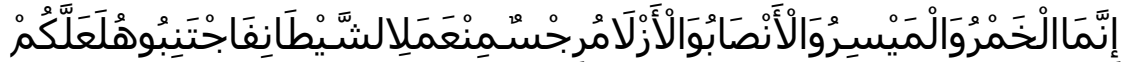

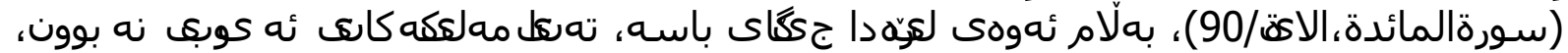

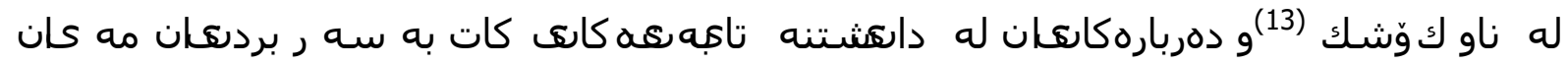

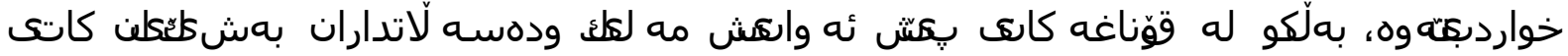

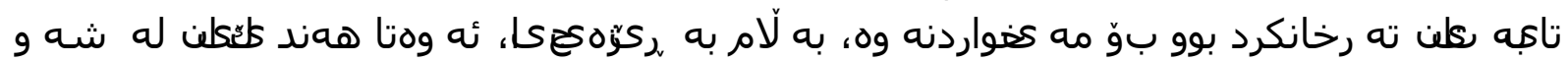

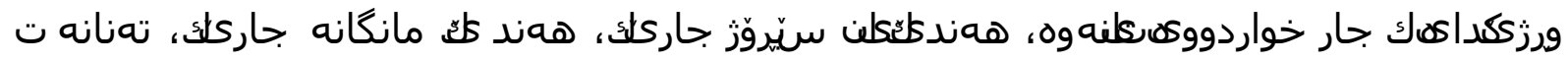

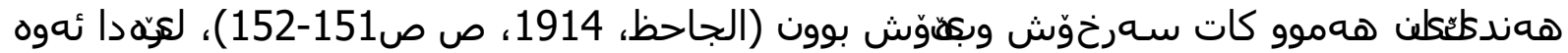

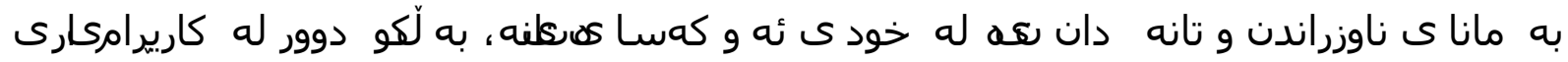




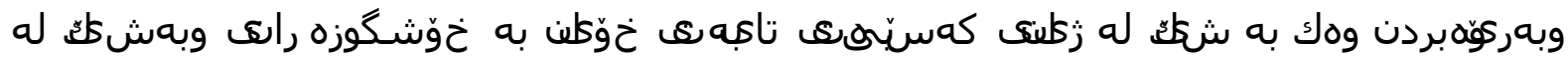

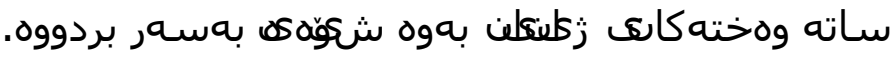

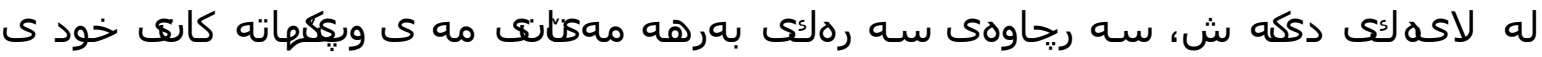

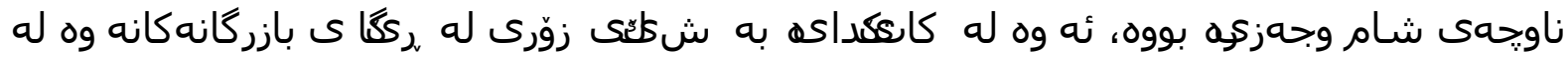

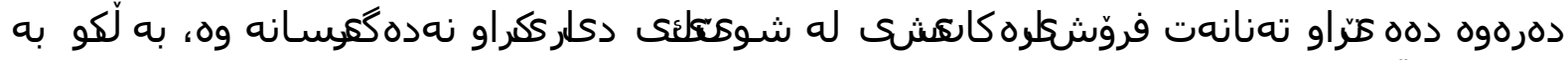

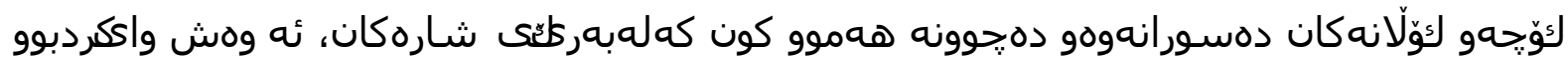

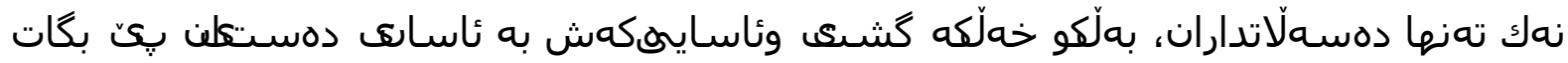

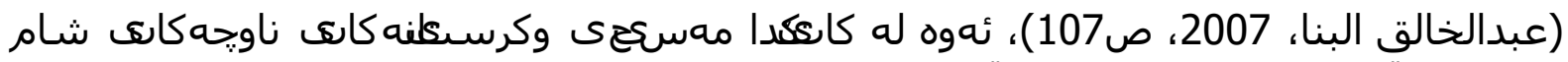

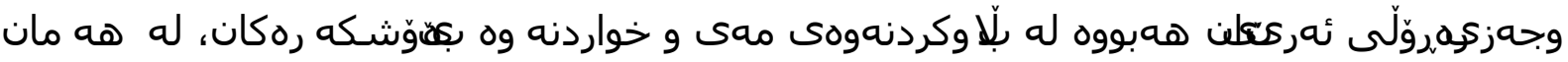

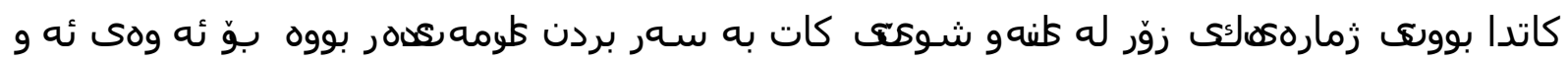

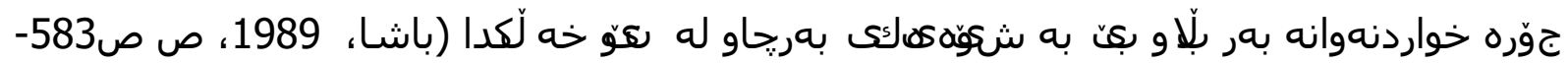
؛584d. Aix, 1896, p: 645.(

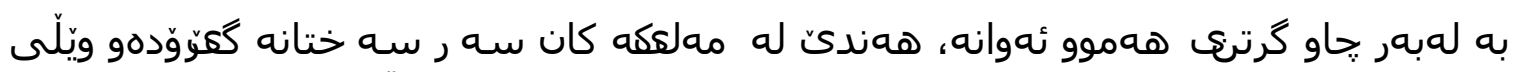

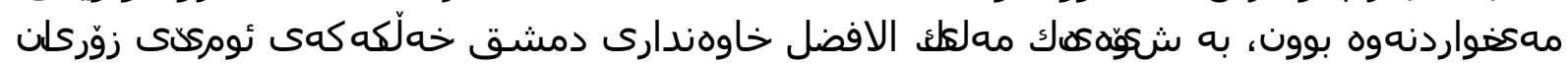

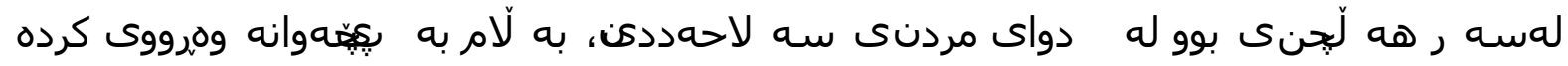

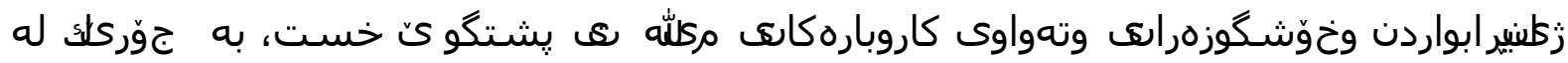

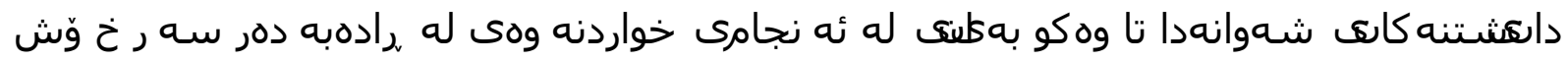

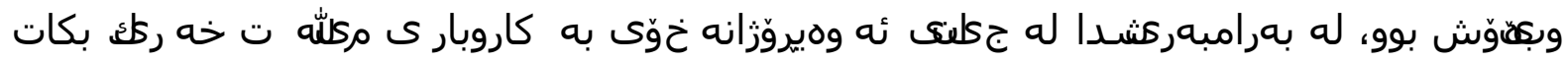

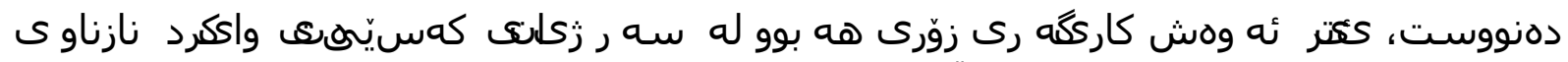

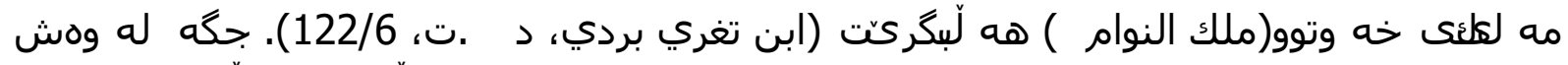

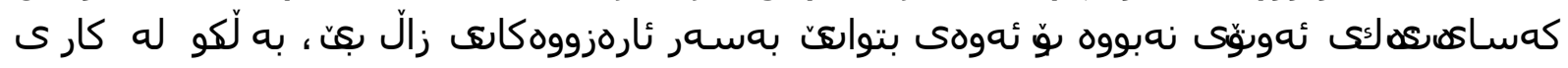

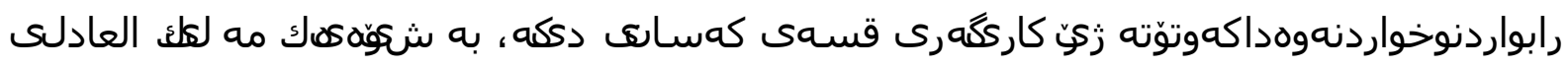

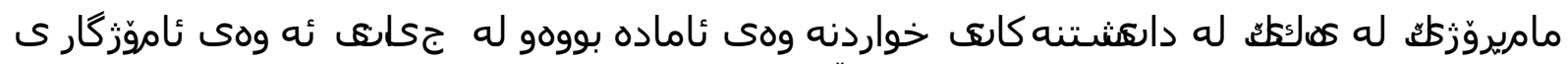

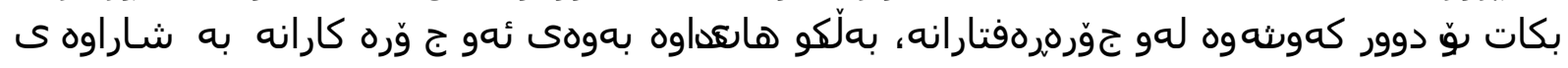

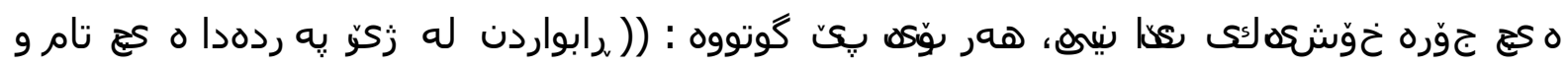

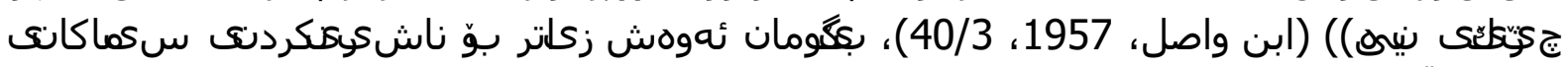

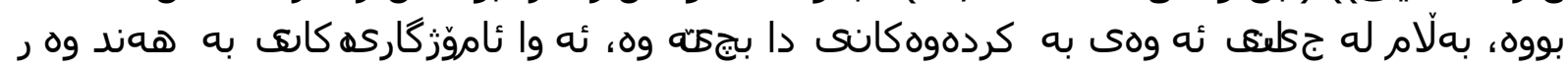

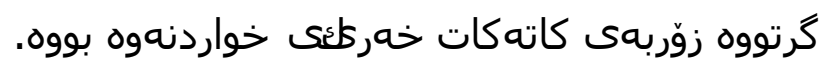

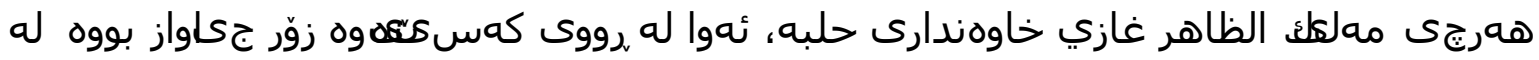

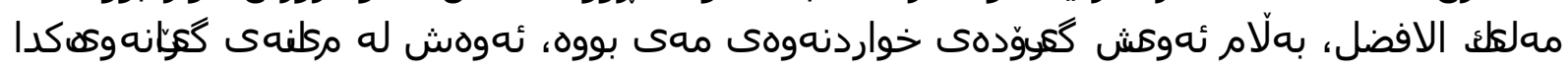

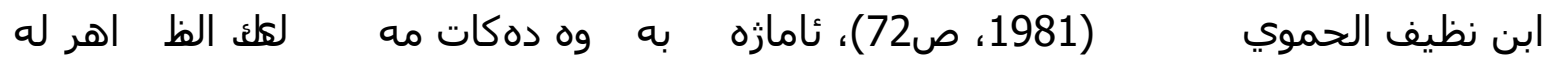

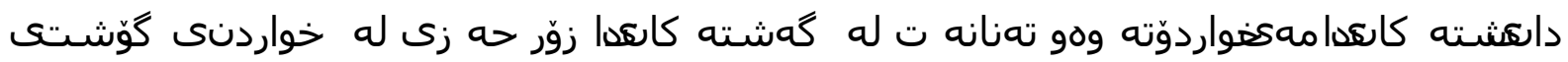

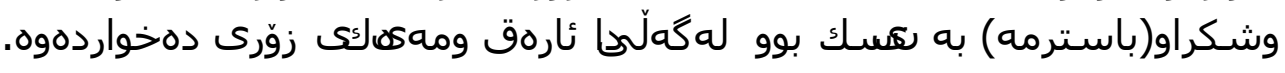

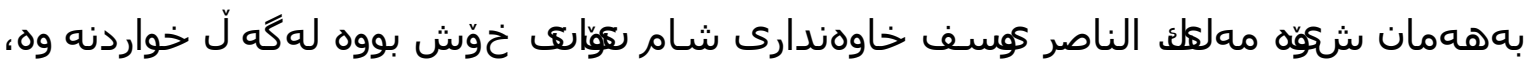

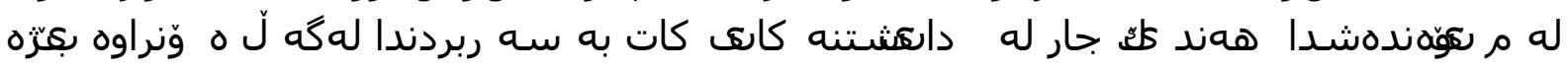

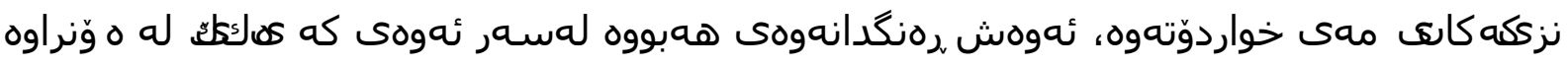

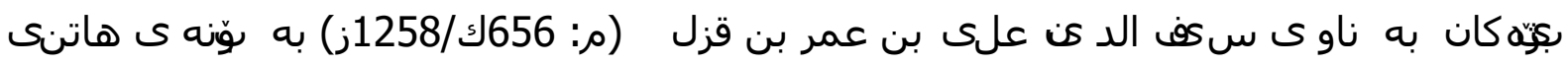

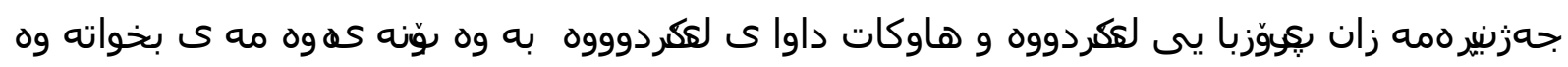

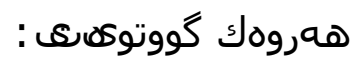




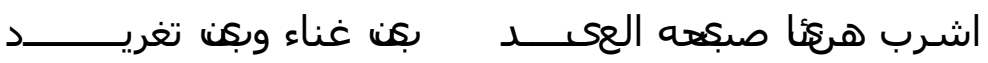

سلاف راح من قبل ما عصرت روقها الكرم فى العناقه

فاكتست رقه الصـــــبا وروت لطافة المزن بالاسانــد

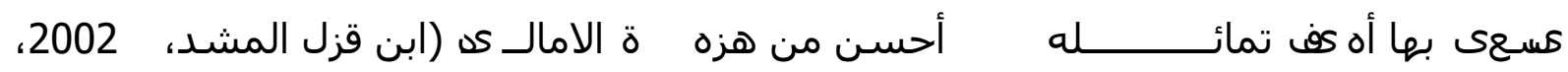
ص369)

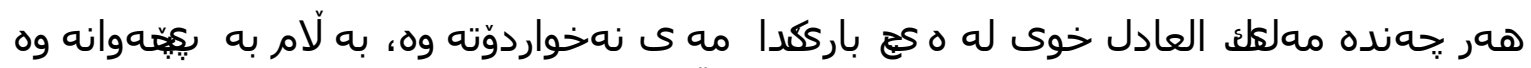

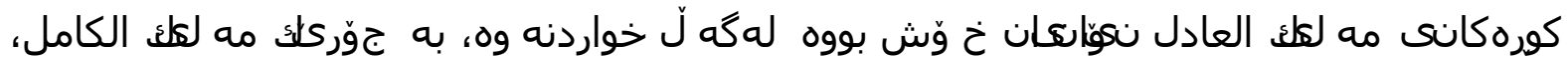

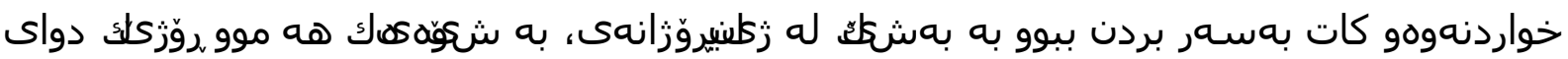

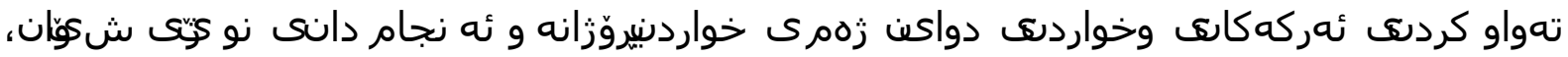

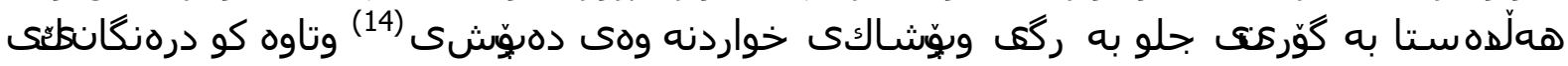

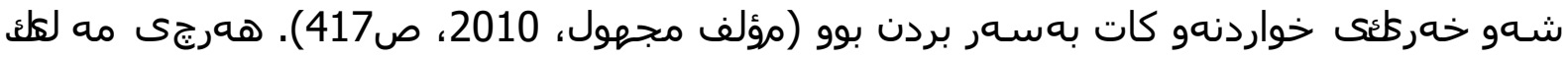

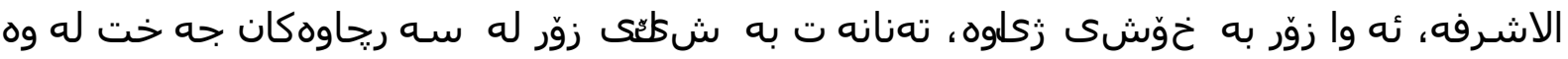

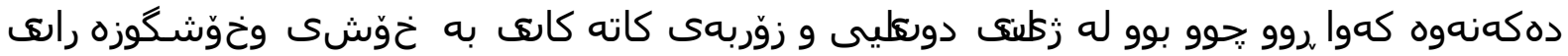

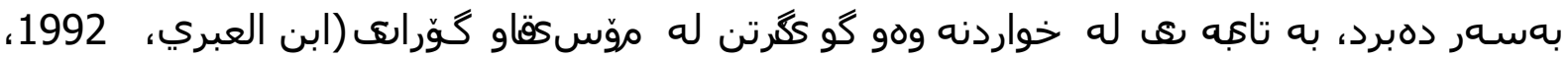

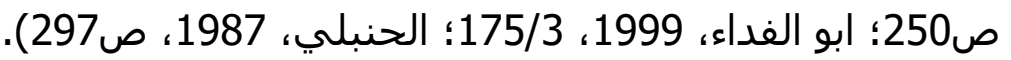

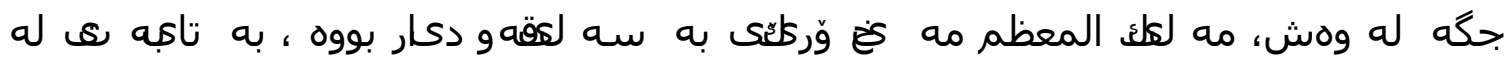

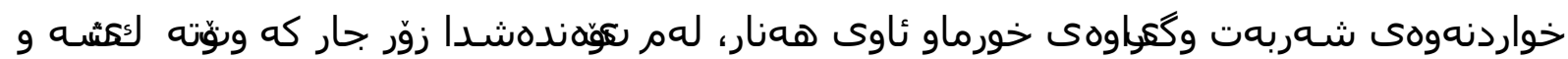

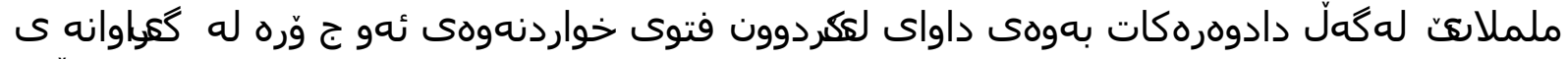

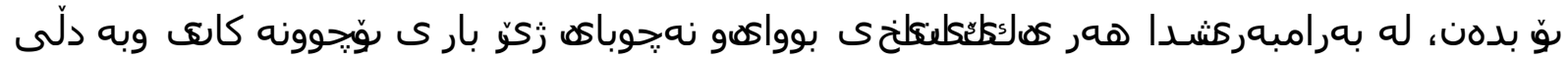

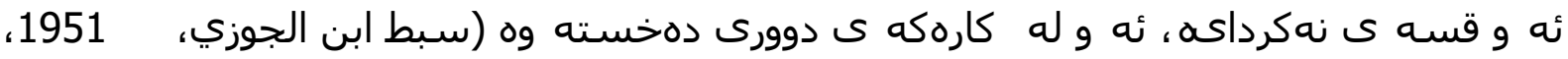

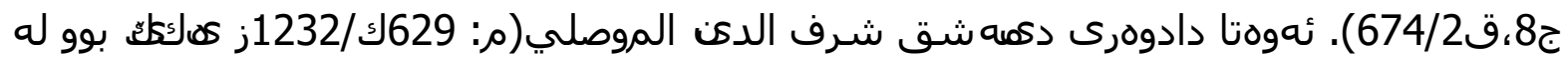

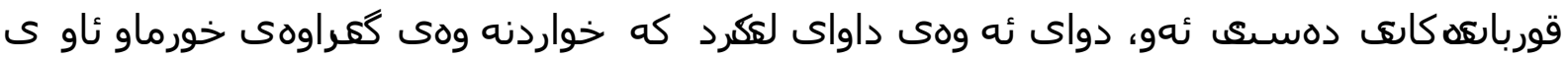

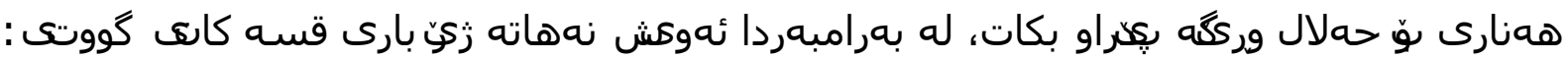

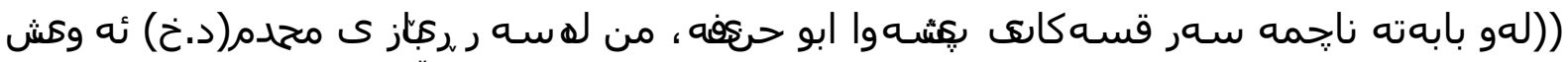

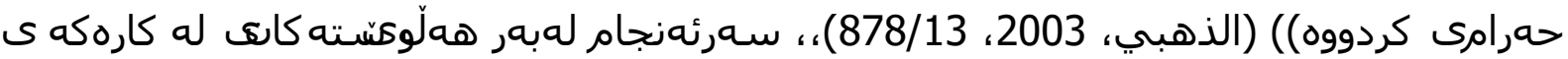

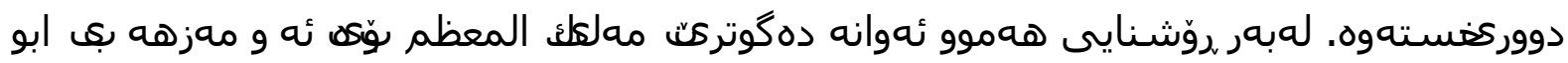

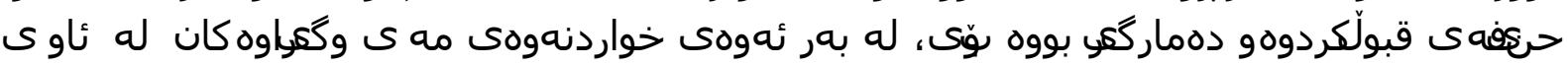

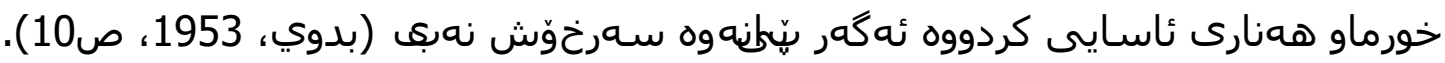

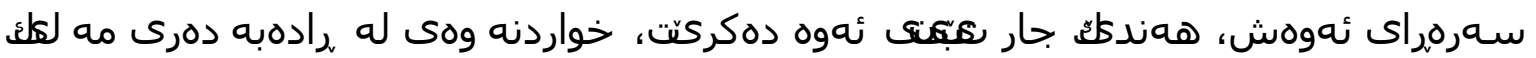

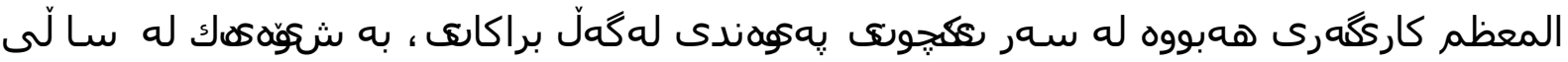

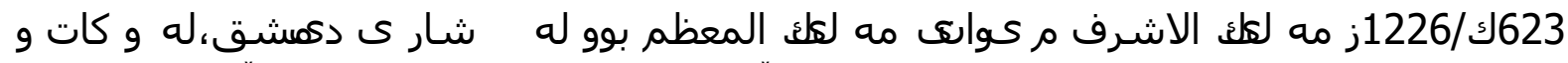

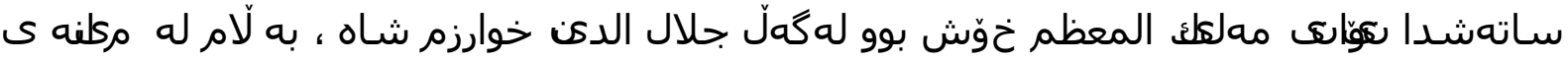

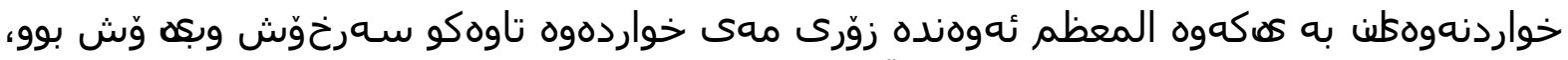

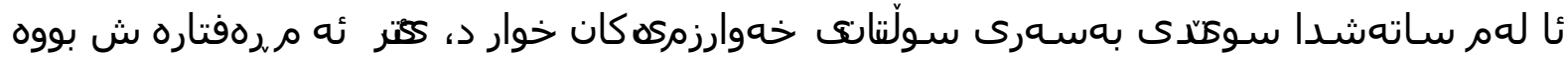

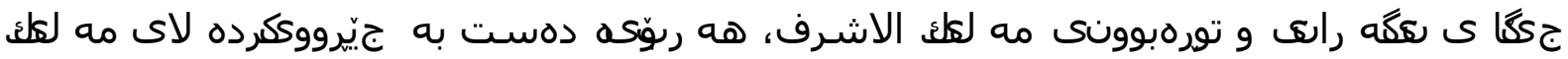

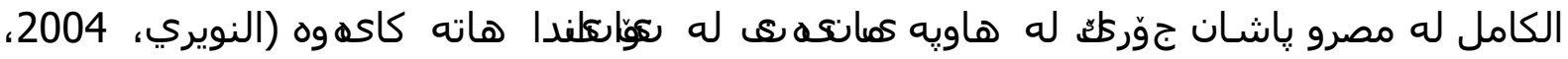

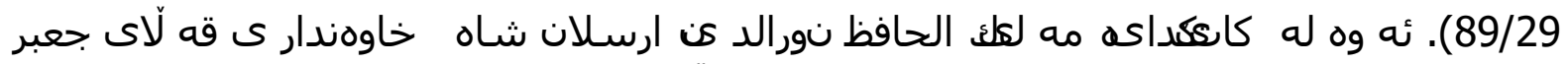

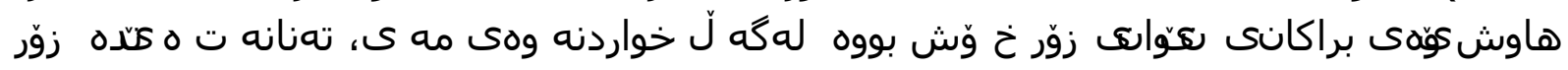




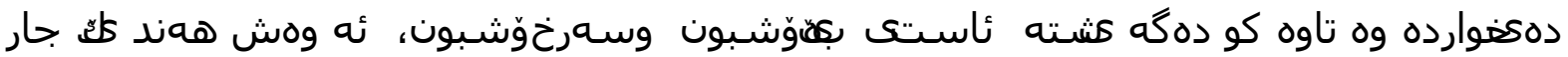

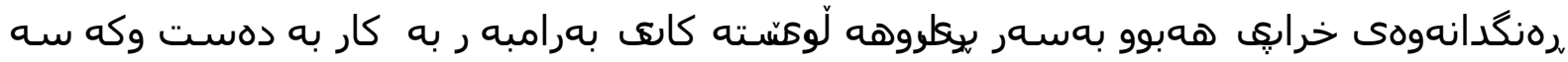

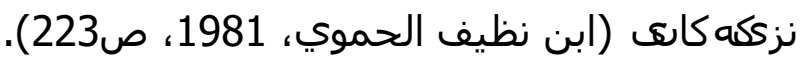

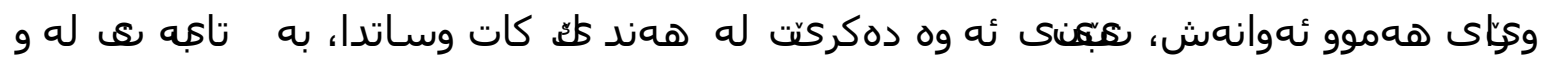

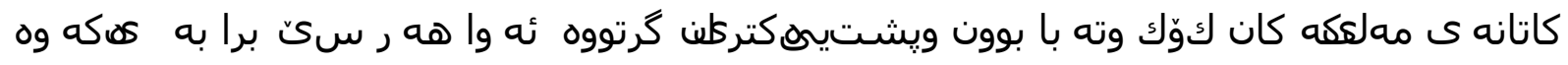

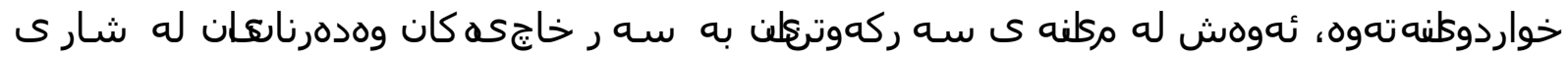

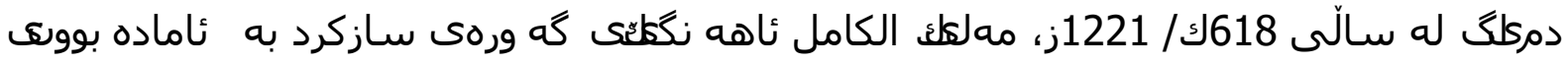

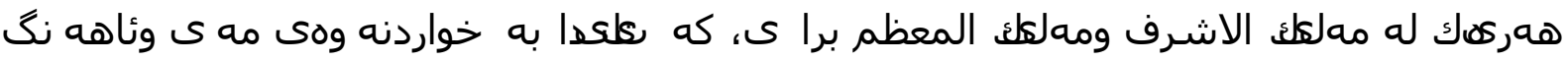

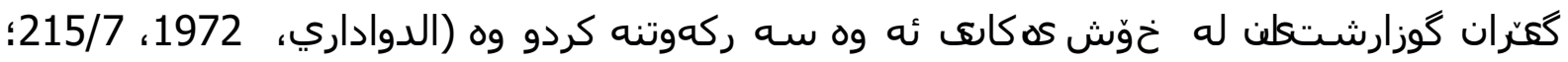
المقركي، 1997، 1997، (329/1).

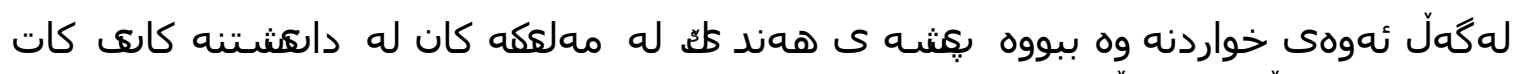

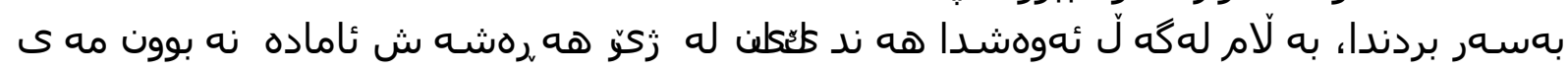

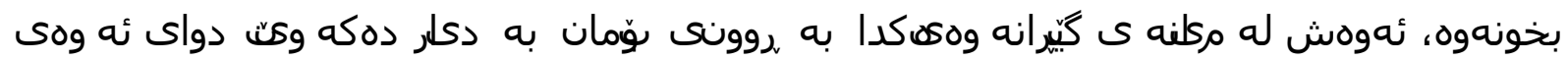

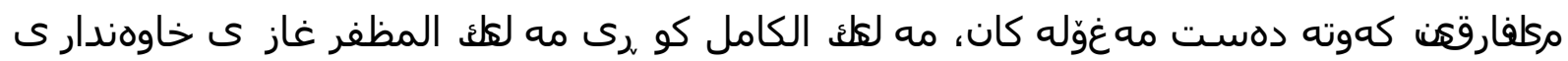

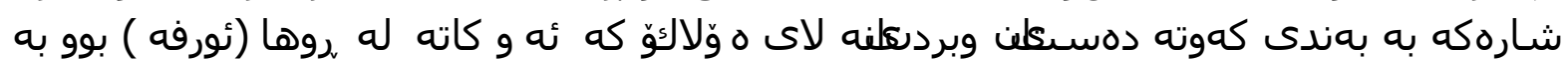

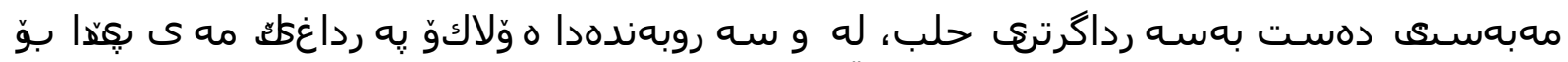

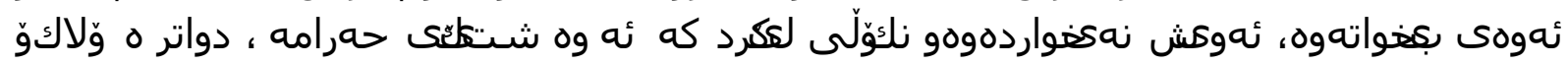

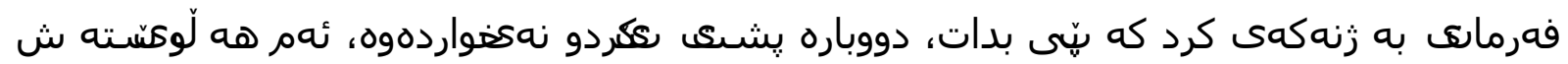

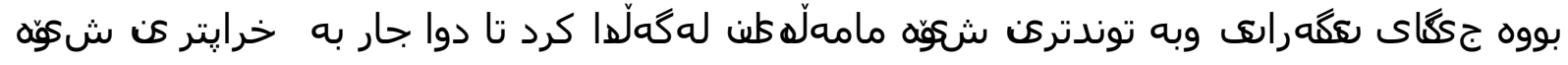

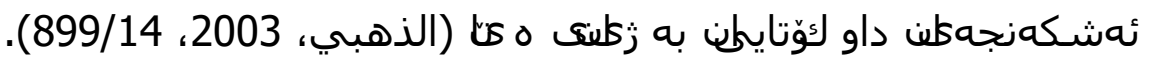

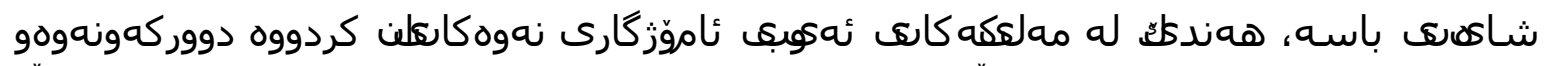

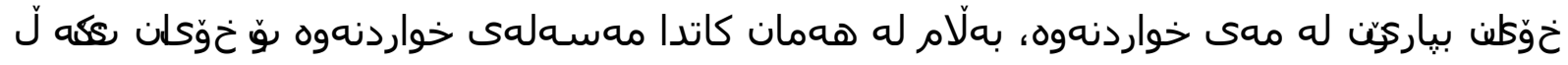

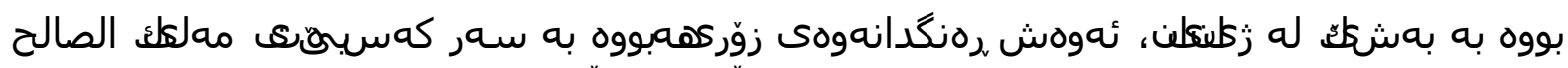

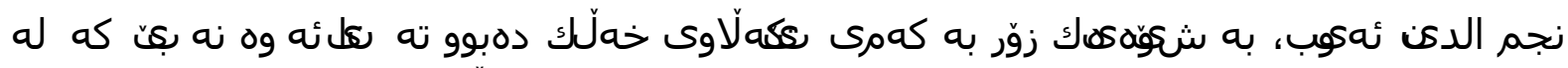

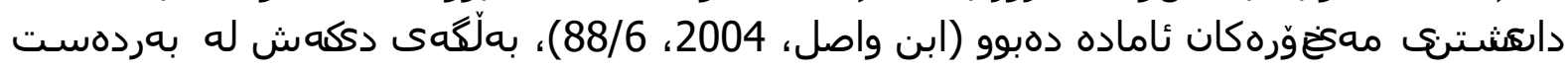

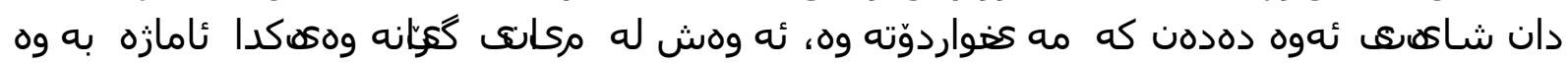

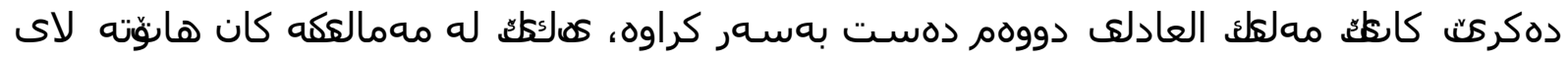

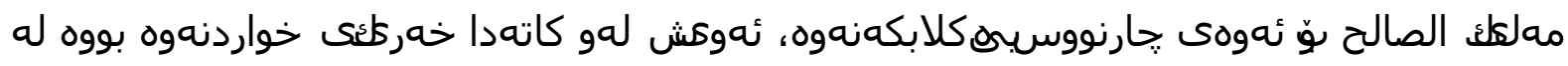

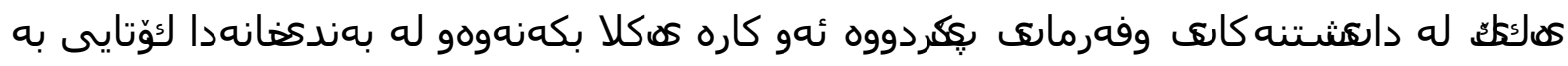

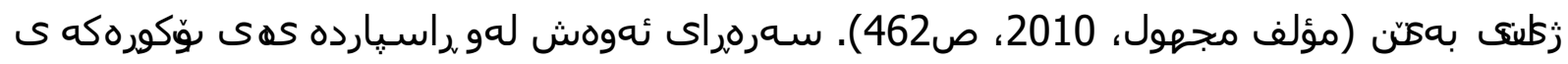

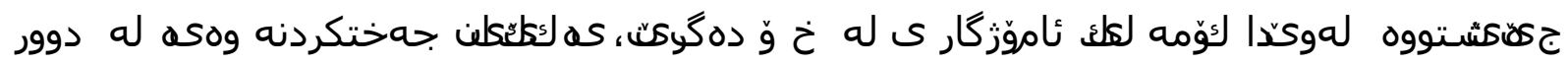

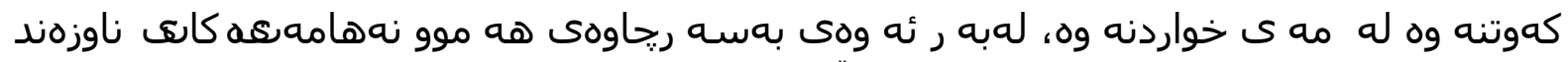

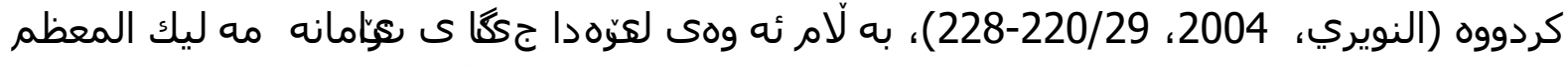

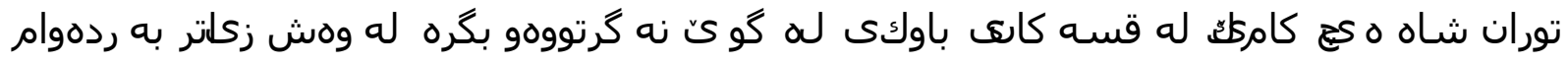

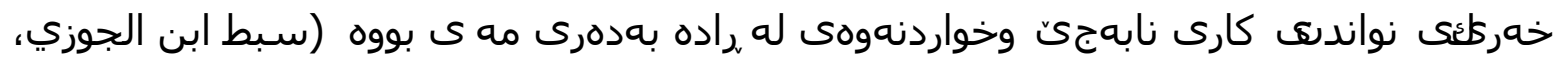

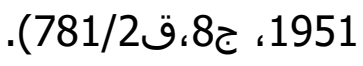

\section{لكوّتايى}




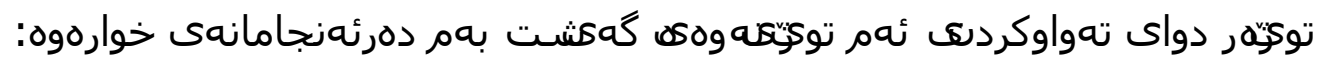

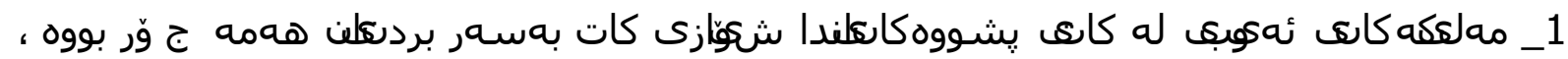

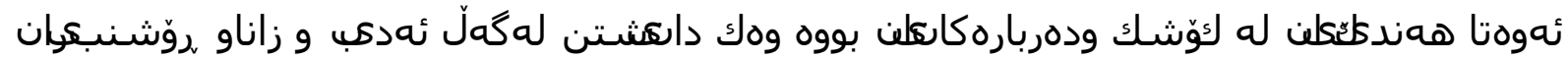

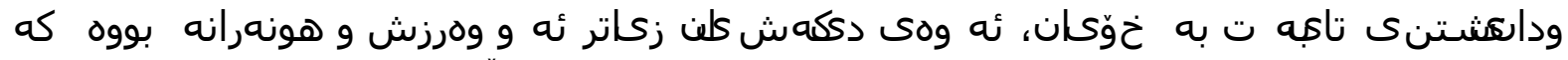

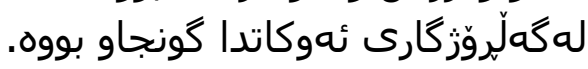

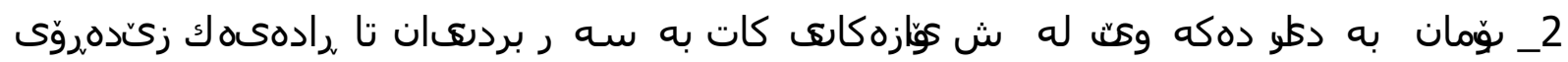

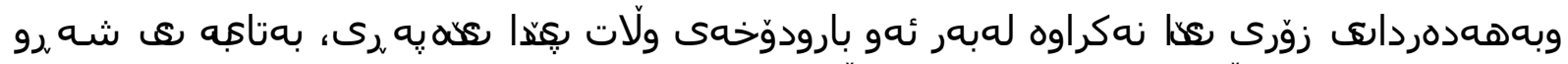

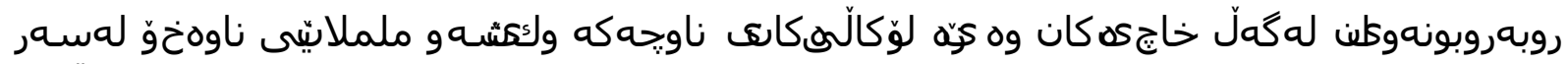
يرسى دهس نلاتات.

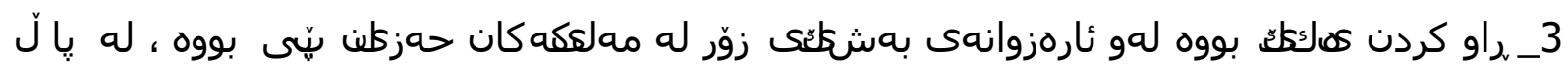

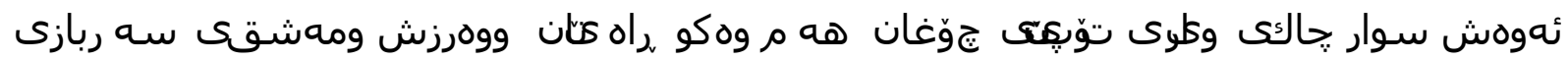
هوم وهكو خوّشى وكات بهسهر بردن.

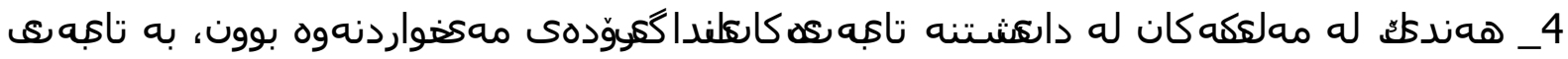

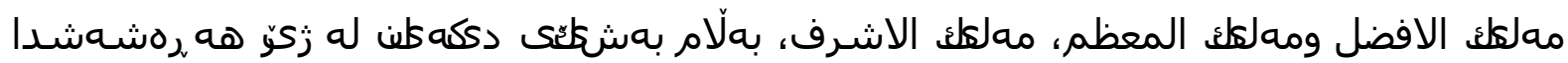

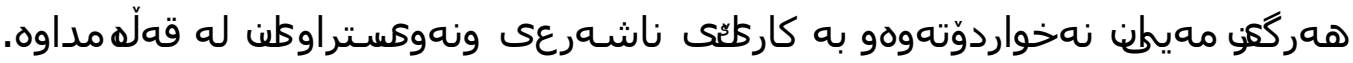

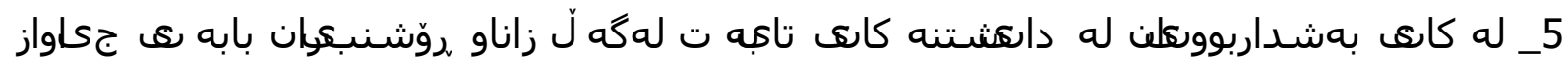

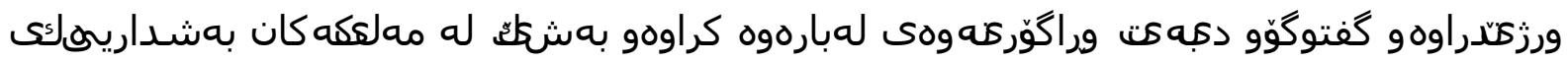

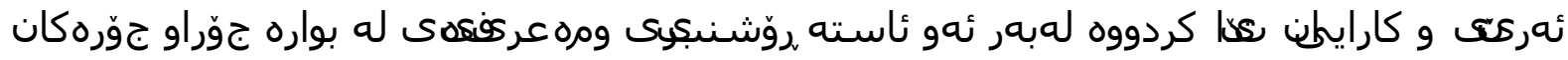
همكلنبوه.

\section{بa راوكنّهان}

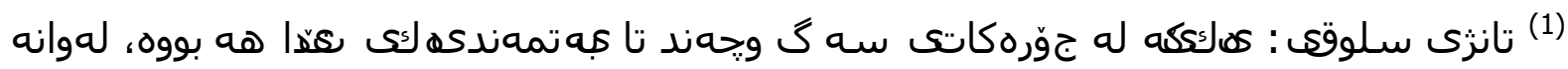

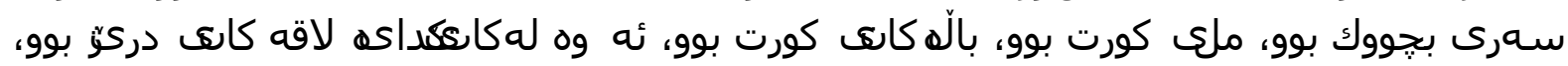

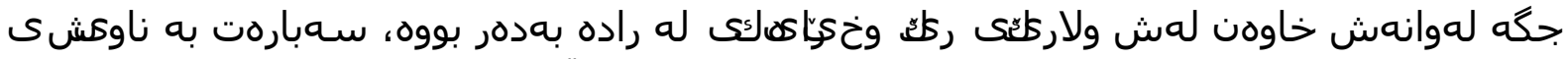

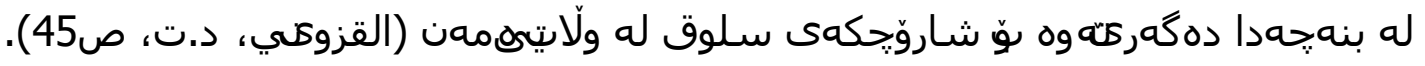

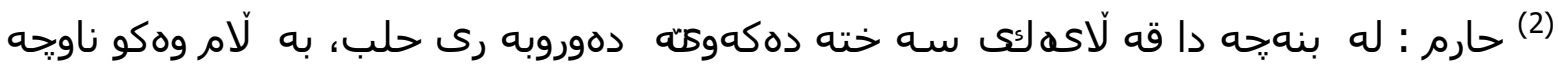

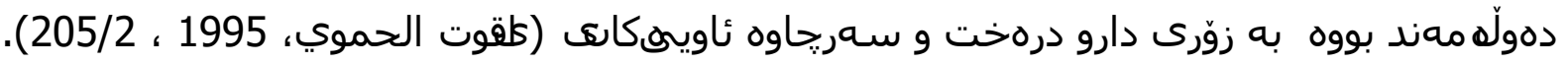

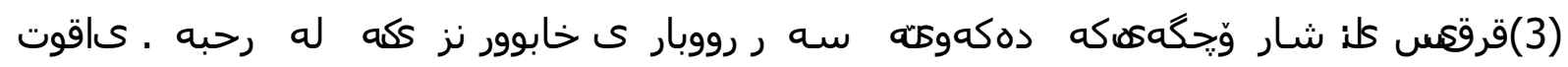

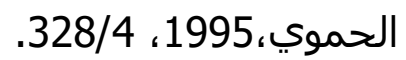

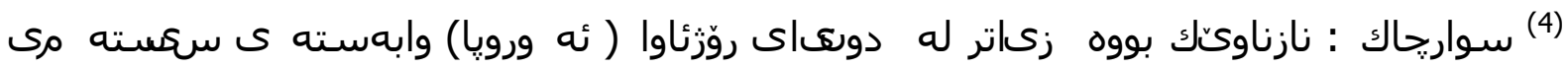

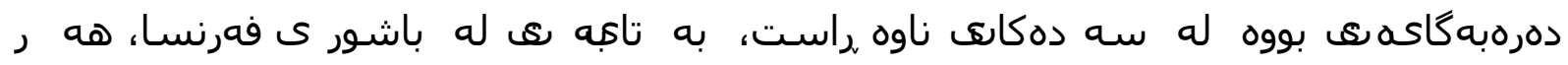

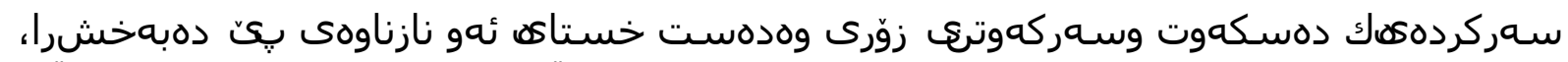

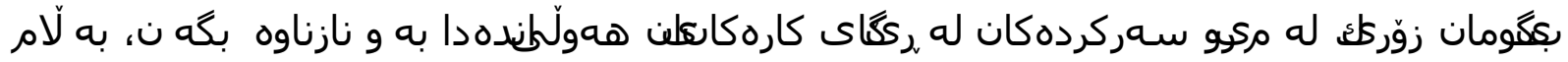

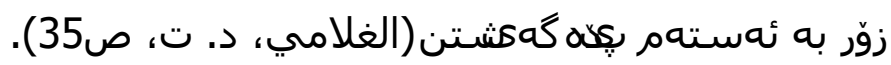


(5) كوّرهيار سهوز: ئهو مaكانه بوو كهوا همفتانه دووجار سـور لهشكرو فهرماندهو سهربازهكان

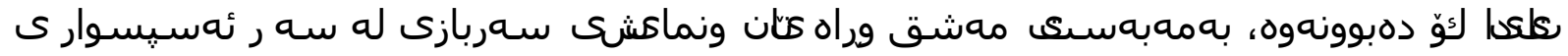

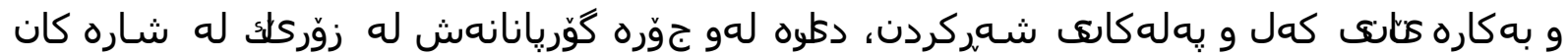

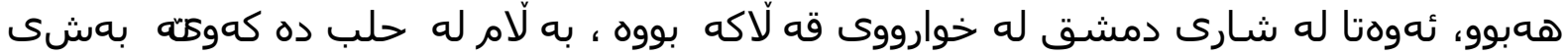

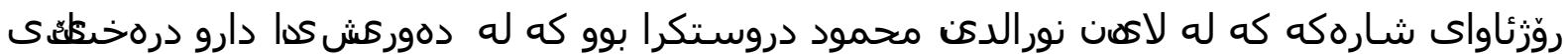

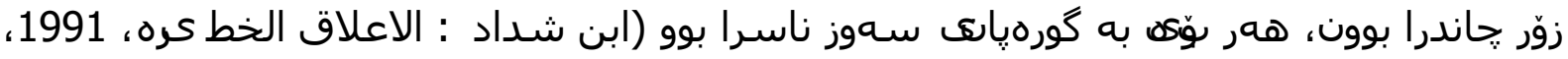

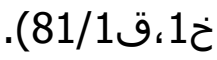

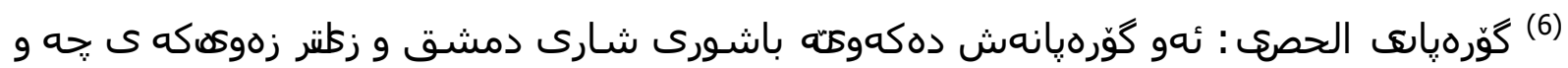

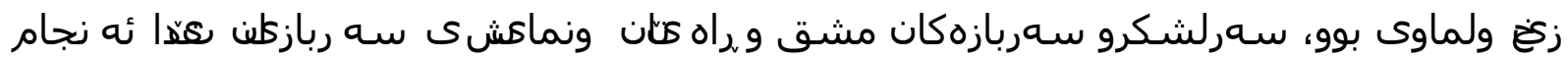

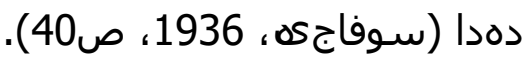

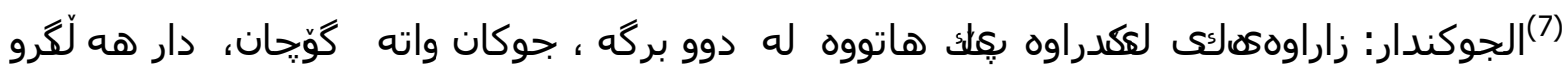

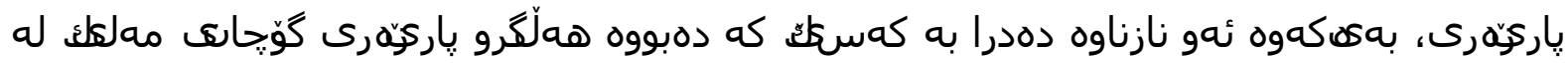

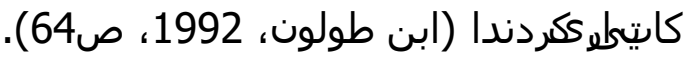

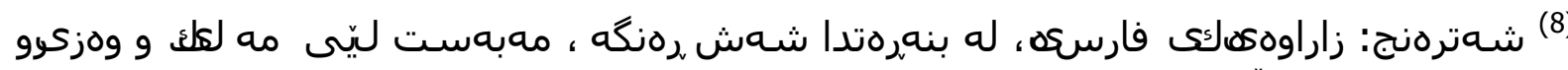

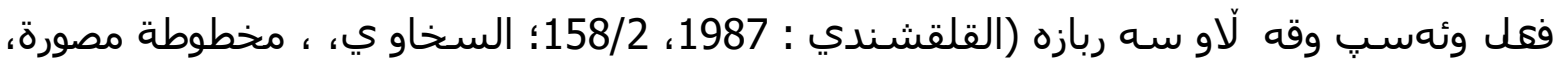

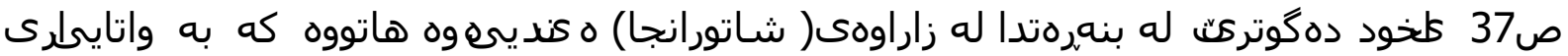

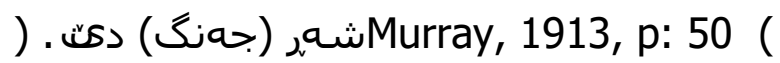

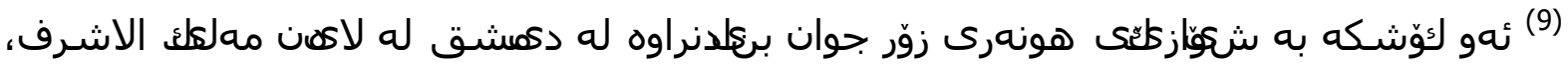

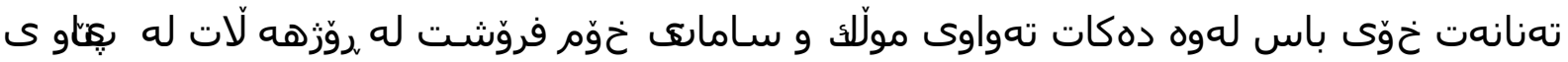

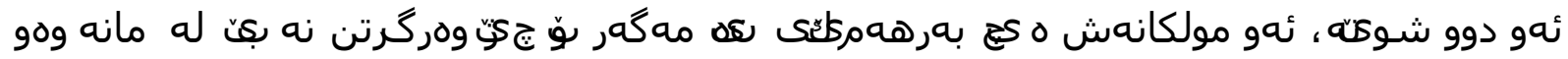

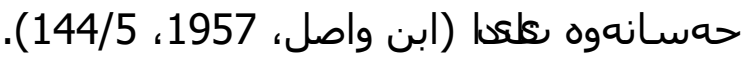

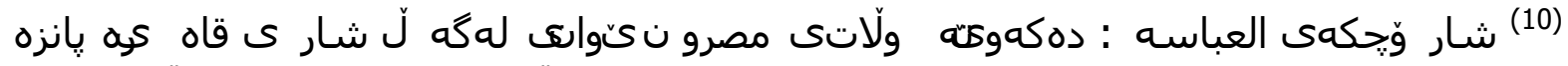

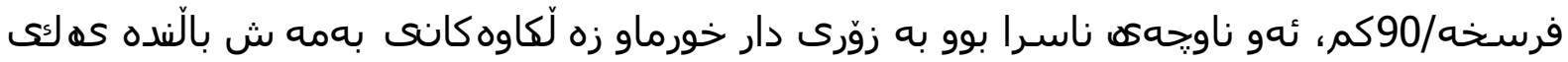

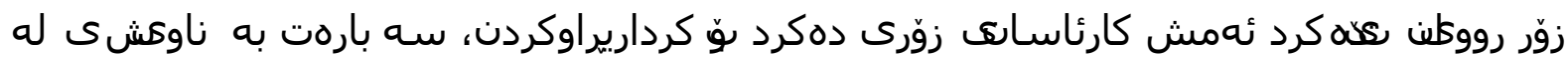

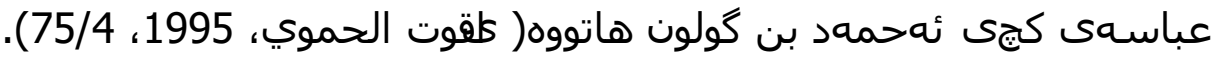

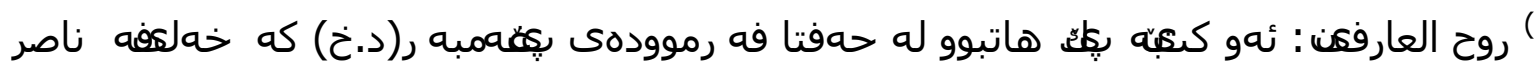

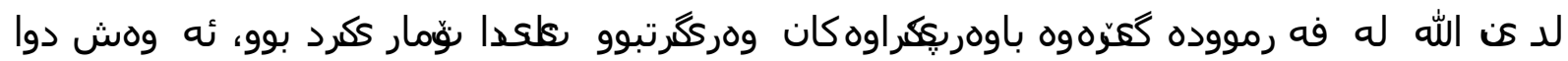

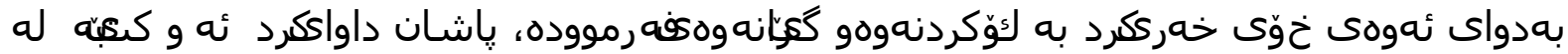

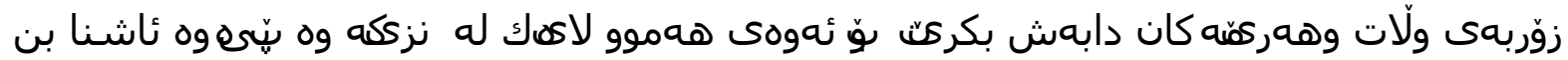

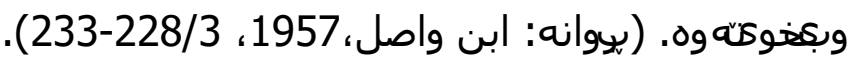

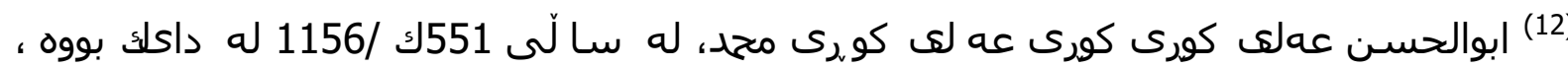

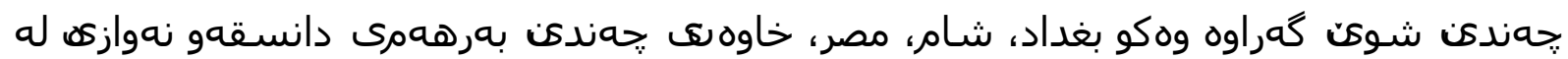

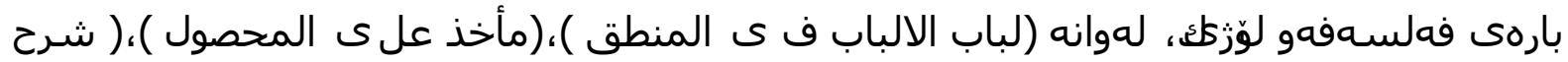

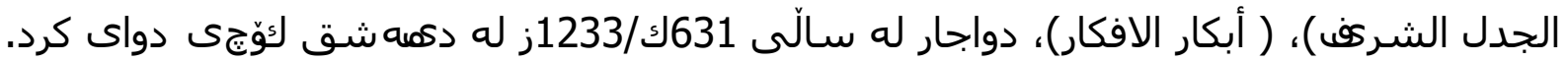

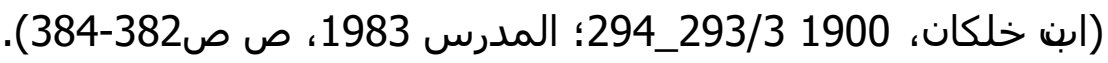

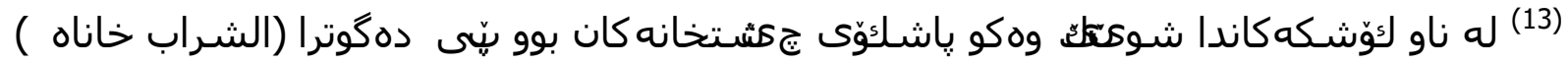

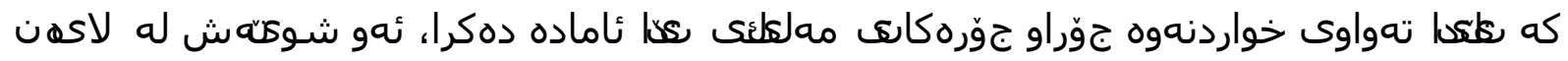




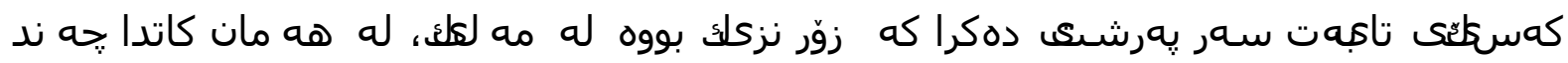

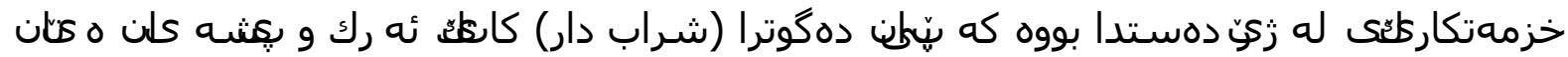

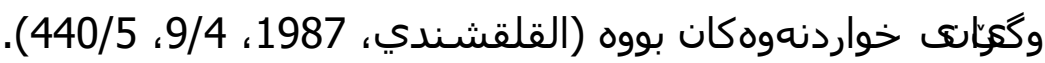

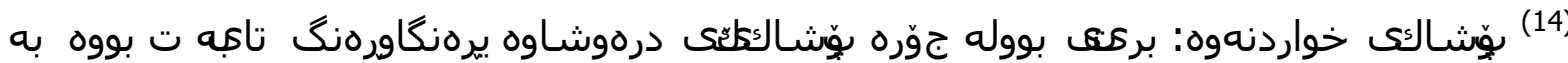

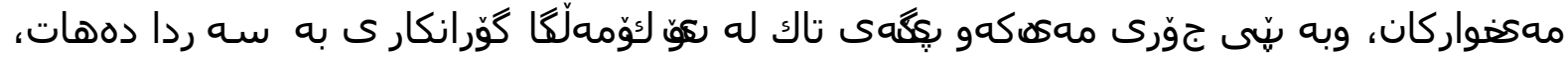

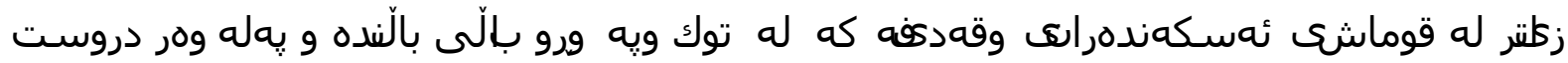

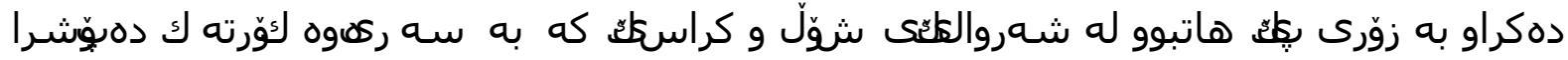

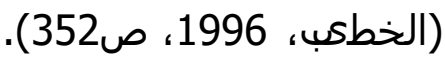

\section{لعسى سaرجاوهكان}

\section{دهستنوس:}

_ السخاوي: شمس الدين محجد بن عبد الرحمن (ت: 902هـ/1497م)

1 1عمدة المحتج في حكم الشطرنج، مخطوطة مصورة، منشور على الموقع الالكتروني www.alukah.net.

\section{سaريحاوهرهسمنهكان:}

_ ابن الاثير: ابو الحسن عز الدين بن علي الشيباني الجزري (ت: 630هـ/1232م)

2_ الكامل في التاريخ، تحقبق : عمر عبد السلام التدمري، دار الكتاب العربي، ط 1(بيروت، (1997

_الاحدب: نجم الدين حسن الرماح(ت: 695هـ/ 1295م)

3 _ الفروسية والمناصب الحربية، تحقيق: عيد ضيف العبادي، وزارة الثقافة والاعلام، (بغداد، .(1984

ـ ابن ابي اصيبعة: موفق الدين احمد بن القاسم (ت: 668هـ/1269م)

4 ـ عيون الانباء في طبقات الاطباء، تحقبق: نزار رضا، مكتبة الحياة،( بيروت، د.ت).

_ ابن تغري بردي: جمال الدين ابو المحاسن يوسف (ت:874هـ/1469م)

5 _ النجوم الزاهرة في ملوك مصر والقاهرة، وزارة الثقافة والارشاد القومي،( مصر، د. ت).

_ الجاحظ: ابو عثمان عمرو بن بحر الكناني (ت:255هـ/ 8666)

6 _ التاج في اخلاق الملوك، تحقيق: احمد زكى باشا، مطبعة الاميرية، ط1( القاهرة، 1914).

_ الجواليقي: ابو منصور موهوب بن احمد بن محد(ت: 540هـ/1145م) 
7_ المعرب من الكلام الاعجمي على حروف المعجم، دار القلم، ط1(دمشق، 1990).

_ الحنبلي: احمد بن ابراهيم (ت: 876هـ/1471)

8 _ شفاء القلوب في مناقب بني ايوب، تحقيق ناظم رشيد، دار الحرية للطباعة، ( بغداد، .)(1978

ـ ابن خلكان: ابو العباس شمس الدين احمد بن محجد (ت: 681هـ/1282م)

9 ـ وفيات الاعيان وانباء ابناء الزمان تحقيق : احسان عباس، ج 1-3، 1990، ج4 1971 دار صادر،(بيروت،1994، (1994).

_ ابو داود: سليمان بن داود بن الجارود الطيالسي(ت: 204هـ/819م)

10 ـ مسند ابى داود الطيالسي، تحقيق: محد بن عبدالمحسن التركي، دار هجر، ط 1( مصر، . (1999

_ الدميري: محدد بن موسى بن عيسى(ت: 808هـ/1406م)

11_ حياة الحيوان الكبرى، دار الكتب العلمية، ط2 (بيروت 2003).

ـ الدواداري: ابو بكر بن عبداله بن ايبك (ت:736هـ/1363م)

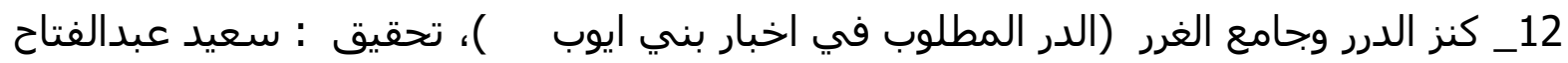
عاشور، دار احياء الكتب العربية،(القاهرة ، 1972).

_ الذهبي: شمس الدين محرد بن احمد عثمان(ت: 748هـ/1347م)

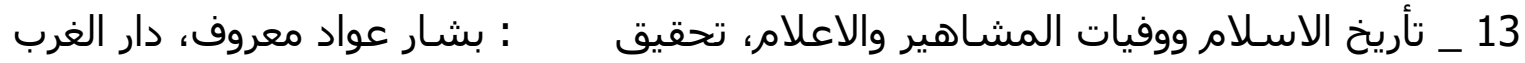
الاسلامي، ط1( بيروت، 2003).

_ سبط ابن الجوزي: شمس الدين يوسف بن قزاوغلي(ت: 654هـ/1256م)

14 _ مراة الزمان في تاريخ الاعيان، مطبعة دائرة المعارف العثمانية، (حيدر اباد، 1951).

ـ السبكي: تاج الدين عبدالوهاب بن علي( ت:771هـ/1369م)

15_طبقات الشافعية الكبرى، تحقيق: محمود محمد الطناحي و عبد الفتاح محخد الحلو، ط 2 (19 1) القاهرة، 1992).

_ ابو شامة: شـاب الدين عبدالرحمن بن اسماعيل المقدسـي(ت: 665هـ/1266م)

16_ تراجم رجال القرنين السادس والسابع المعروف بالذيل على الروضتيتن ، وضع حواشيه الريه وعلق عليه: ابراهيم شمس الدين المعروف، دار الكتب العلمية، ط1 ( بيروت، 2002).

17 _ الروضتين في اخبار الدولتين النورية والصلاحية ، تحقيق ابراهيم الزيبق، مؤسسة الرسالة،( بيروت، 1997)

ـ ابن شداد: بهاء الدين يوسف بن رافع( ت: 632هـ/1234م) 


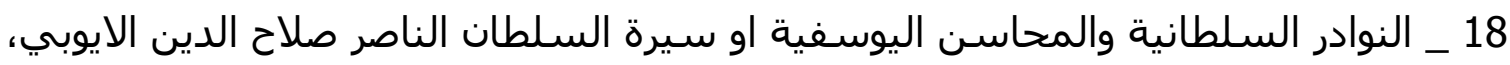
تحقيق: احمد ايبش، (دمشق، 2005).

ـ ابن شداد: عز الدين مجد بن علي بن ابراهيم (ت: 684هـ/1285م)

19 _ الاعلاق الخطيرة في ذكر الامراء الشام والجزيرة ، تحقيق : يحيى زكريا عبارة، منشورات وزارة الثقافة والارشاد القومي، ط1 إدمشفي عبارة، 1987).

ـ شرف الدين الانصاري: عبد العزيز محد بن عبدالمحسن الحموي (ت: 662هـ/1223م)

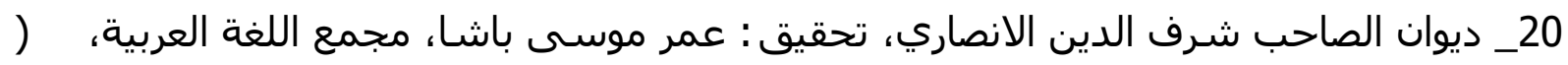

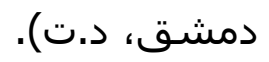

ـ ابن الشعار: كمال الدين ابي البركات المبارك بن الشعر الموصلي(ت:654هـ/1256م)

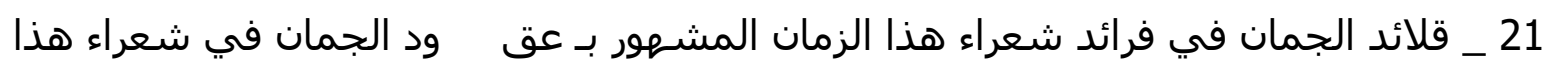
الزمان، تحقيق: كامل سلمان الجبراء هذان المشي، دار الكتب العلمية، ط1( بيروت، 2005).

_ الصفدي: صلاح الدين خليل بن ايبك( ت:764هـ/1363)

22 _ الوافي بالوفيات، تحقيق : احمد الارناؤوط وتركي مصطفى، دار احياء التراث، (بيروت، . (2000

ـ ابن طولون: شمس الدين محد بن طولون الدمشقي ( ت:953هـ/1546م)

23_ نقد الطالب لزغل المناصب، تحقيق : محد احمد دهمان وخالد مجحد دهمان، راجعه : نزار اباظة، دار الفكر المعاصر، (بيروت، 1992)

ـ العباسي: حسن بن عبداله (ت:710هـ/1310م)

24_ آثار الاول في ترتيب الدول، تحقيق: عبدالرحمن حممة، دار الجيل، ط1(بيروت، 1989).

_ ابن العبري: غريغوريوس بن هارون الملطي(ت: 685هـ/1286م)

25_ تأريخ مختصر الدول، تحقيق: انطوان صالحاني اليسوعي، دار الشـرق، ط3(بيروت، 1992).

_ ابن العديم: كمال الدين ابو القاسم عمر بن احمد(ت: 660هـ/1261م)

26_ بغية الطلب في تاريخ حلب، تحقيق: سهيل زكار، دار الفكر،(بيروت، 1988).

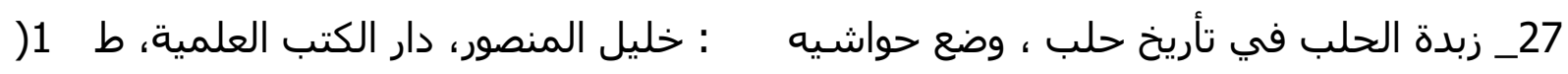
بيروت، 1996)

_ ابو الفداء: الملك المؤيد عماد الدين اسماعيل بن محردت: 732هـ/1321م)

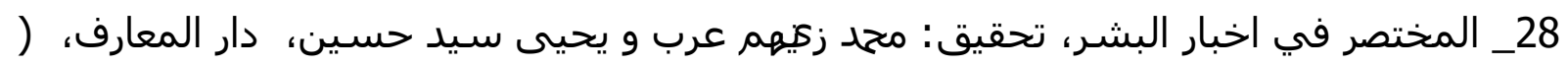

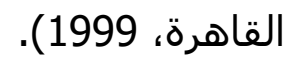

_ ابن فضل الله العمري: شهاب الدين احمد بن يحيى(ت: 749هـ/1378م) 
29 _ مسالك الابصار في ممالك الامصار، المجمع الثقافي، ط1(ابو ظبي، 1423هـ/2002م)

_ ابن الفوطي: عبدالرزاق بن احمد (ت: 723هـ/1323م)

33 _ تلخيص مجمع الأداب في معجم الألقاب، تحقيق : مصطفى جواد، مطبعة مديرية أحياء التراث القديم، (دمشق، مديعة 1962).

_ ابن قتيبة الدينوري: ابو محجد عبدالله بن مسلم (ت:276هـ/

30_عيون الاخبار، دار الكتب العلمية، (بيروت، 1418هـ/1997م).

ـ ابن قزل المشد: سيف الدين علي بن عمر (ت: 656هـ/1258م)

31 _ ديوان ابن قزل المشد، تحقيق: مشهور عبدالرحمان الحبازي،( القدس، 2002).

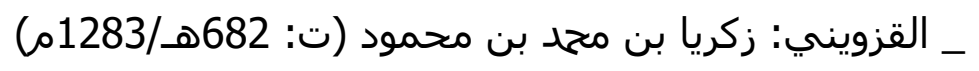

32 _ آثار البلاد وخبار العباد، دار صادر، (بيروت، د.ت).

_ القفطي: جمال الدين ابو الحسن علي بن يوسف (ت:646هـ/1248م)

33 _ انباه الرواة على انباه النحاة، تحقيق: محدد ابو الفضل ابراهيم، مؤسسة الكتب الثقافية،

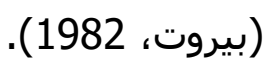

_ القلقشندي: ابو العباس احمد بن علي الفزاري (ت:821هـ/1418م)

34_ صبح الاعشى في صناعة الانشا ، تحقيق مجحد حسين شمس الدين ، دار الكتب

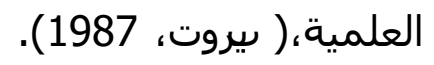

35_مآثر الانافة في معالم الخلافة، تحقيق : عبدالستار احمد فراج، مطبعة حكومة الكويت، ط2(الكويت، 1985).

ـ ابن قيم الجوزية: محمد بن ابي بكر بن ايوب (ت:751هـ/1351م)

36 _ الفروسية، تحقيق: مشهور بن حسـن بن محمود بن سلمان، دار الاندلس، ط1(السعودية، (1993

_ الكتبي: محمد بن شاكر بن احمد (ت: 764هـ/1363م)

37 ـ فوات الوفيات، تحقيق: احسان عباس، دار صادر،( بيروت، 1974).

_ ابن كثير: ابو الفداء اسماعيل بن عمر (ت:774هـ/1373م)

38 _ البداية والنهاية ، تحقيق: علي شيري، دار احياء والتراث العربي، ( بيروت،1988).

39_ طبقات الشافعيين، تحقيق : احمد عمر هاشم و محد زينهم محخد عزب، مكتبة الثقافة

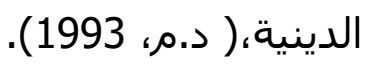

ـ ـ المسعودي: ابي الحسن علي بن الحسين (ت: 346هت/2057) 
40_ مروج الذهب ومعادن الجوهر، تحقيق: محجد هشام النعسان وعبدالمجيد طعمه حلبي، دار (بيرو،

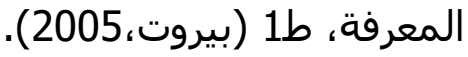

_ مسلم بن حجاج: ابو الحسن مسلم بن حجاج القشيري (ت: 261هـ/874م)

41 _ صحيح مسلم، تحقيق: محد فؤاد عبدالباقي، دار احياء التراث العربي،( بيروت، د.ت).

_ ابن المعتز: عبدالله بن محمد العباسي (ت:296هـ/908م)

42 _ طبقات الشعراء، تحقيق: عبدالستار احمد فراج، دار المعارف، ط3( القاهرة، د.ت).

ـ المقريزي: تقي الدين ابي العباس احمد بن علي (ت: 845هـ/1441م)

43_ السـلوك لمعرفة دول الملوك، تحقيق: محد عبدالقادر عطا، دار الكتب العلمية، ط 1( بيروت، 19. (1997

_ الملك الناصر داود: داود بن عيسى الايوبي (ت: 656هـ/1258م)

44 _ الفوائد الجلية في الفرائد الناصرية (رسائله وشعره)، تحقيق : ناظم رشيد، دار الشؤون

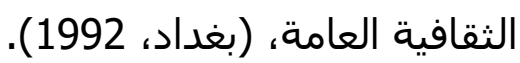

ـ ابن منقذ: أسامة بن مرشد بن علي الشيزري (ت:584هـ/1188م)

45 _ الاعتبار، حرره: فليب حتى، مكتبة الثقافة الدينية،( مصر، د.ت).

_ مؤلف مجهول: ( توفي بعد 655هـ/1257م)

46 _ تاريخ دولة الاكراد والاتراك (تاريخ دولة الاكراد )، دراسة وتحقيق : موسى مصطفي

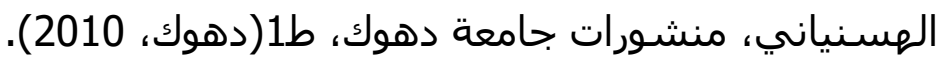

_ مؤلف مجهول: (من مؤلفات القرن السابع الهجري)

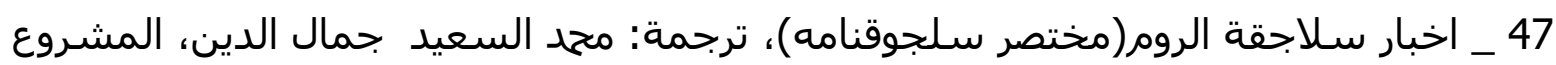
القومي للترجمة، (القاهرة، 2007).

ـ ابن نظيف الحموي: ابو الفضائل مححد بن علي ( ت:644هـ/1246م)

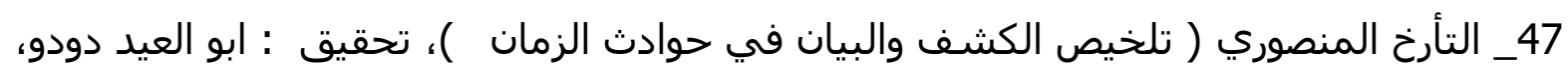

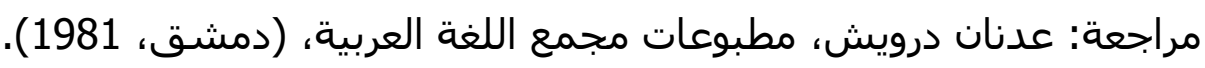

_ النويري: شـاب الدين أحمد بن عبدالوهاب بن مجحد (ت:733هـ/1322م)

49 _ نهاية الارب في فنون الادب، تحقيق : نجيب مصطفى فواز و حكمت كشلي فواز، دار الكتب العلمية، ( بيروت، 2004) في فوارن

_ ابن واصل: جمال الدين مخد بن سالم (ت: 697هـ/1297م)

50 _ التأريخ الصالحي، تحقيق: عمر عبدالسلام تدمري، المكتبة العصرية، (بيروت، 2010). 
51 _ مفرج الكروب في اخبار بني ايوب، ج1_5، تحقيق: جمال الدين الشيال، مطبعة الاميرية، (

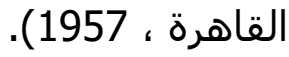

52_ مفرج الكروب في اخبار بني ايوب، ج 6 6، تحقيق : عمر عبدالسلام التدمري، المكتبة العصرية،( بيروت، 2004).

ـ ياقوت الحموي: شـاب الدين عبدالله الرومي (ت:626هـ/1229م)

53 _ معجم البلدان، دار صادر، ط2( بيروت، 1995).

ـ اليونيني: قطب الدين موسى بن محهد (ت: 726هـ/1326م)

54 ـ ذيل مرآة الزمان، دار الكتب الاسلامي، ط2( القاهرة، 1992م).

\section{ز5كان}

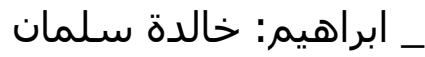

55 _ الحياة الاجتماعية في مصر في العصر الايوبي(567-648هـ /1171-1250م)، دار البصائر للطباعة والنشر، ط1(بيروت، 2013).

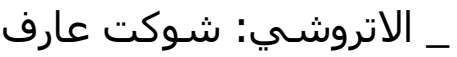

56_ الحياة الفكرية في مصر خلال العصر الايوبي،(عمان،2007).

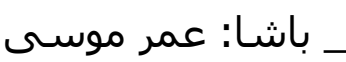

57 _ الادب في بلاد الشام عصور الزنكيين والا يوبيين والمماليك، دار الفكر، ط 1( دمشق، (1989)

_ بدوي: احمد احمد

58 _ مأمون بني ايوب المعظم عيسى، مطبعة لجنة البيان العربي،( القاهرة، 1953).

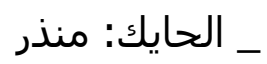

59 _ مملكة حمص في العصر الايوبي، تقديم: سـيل زكار، دار طلاس، (دمشق، 2000).

_ الخطيب: مصطفى عبدالكريم

60_ معجم المصطلحات والالفاظ التاريخية،( بيروت، 1996)،

ـ رجب: عبد الجواد ابراهيم

61 ـ الفاظ الحضارة في القرن الرابع الهجري دراسة في ضوء مروج الذهب

للمسعودي،(القاهرة، 2003).

ـ ـ السامرائي: فراس سلمي حياوي 
62_التقاليد والعادات الدمشقية خلال عهود السلجوقيين- الزنكيين- الايوبيين، دار الأؤائل للنشر (دمر والتوزيع،(دمشق، الارول2004).

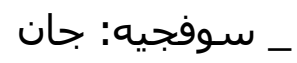

63_ دمشق الشام،(بيروت، 1936)

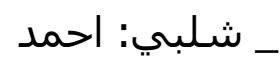

64 _ الحياة الاجتماعية في الفكر الاسلامي، مكتبة النهضة المصرية، ط5( القاهرة، 1986).

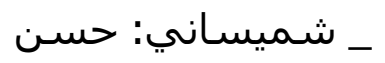

65 _ مدينة سنجار من الفتح العربي الاسلامى ح تى الفتح العثماني، دار الافاق الجديدة،

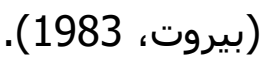

_ الطيار: عبدالله بن مجد بن احمد

66 _ توجيه وتنبيه الى هواة الصيد ومحبيه، دار المتعلم للنشر والتوزيع، ط1(الرياض، 2003). _ عبدالخالق البنا: عبد الحافظ

67 _ اسواق الشام في عصر الحروب الصليبية، مطبعة عين للدراسات والبحوث الانسانية والاجتماعية، ط1(القاهرة، 2007).

_ _ الغلامي: عبدالمنعم

68_ماثر العرب والاسلام في القرون الوسطى، مطبعة أم الربيعين، (الموصل، د.ت).

_ المدرس: عبد الكريم مجرد

69_ علماؤنا في خدمة العلم والدين، عني بنشـره: مجد علي القرداغي،( بغداد، 1983).

_ مصطفى: شاكر

70_ المدن في الاسلام حتى العصر العثمانى، دار ذات السلاسل للطباعة والنشر،ط1(الكويت، (1988

_ نصار: لطفي احمد

71 ـ وسائل الترفية في عصر سلاطين المماليك في مصر، مطبعة الهيئة المصري العامة

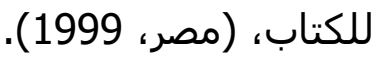

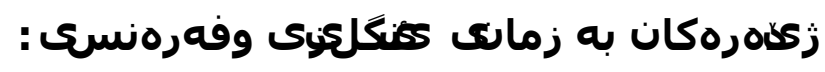

D. Aix: Albert_

_ Historia Nicenae Vel Anticochenae prologum, (Paris, 1896). 72 
Murray: H.X.R

History of chess, (Oxford, 1913). $\quad 73$

\section{نامه زانكُوّيه لِّاو نهكراوهكان:}

_ الصايغ: هنرييت زاهى سايا

ـ اتجاهات الشعر العربي في القرن السابع الهجري في بلاد الشام، اطروحة دكتوراه، كلية 74 الطعرة الاداب_جامعة القاهرة، (القاهرة، 1980).

_ نوري: نوفل مجد

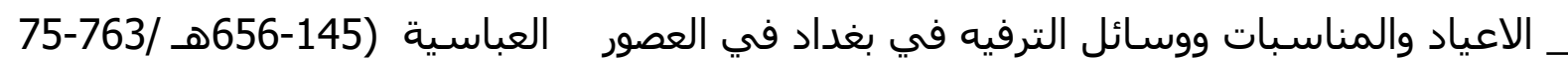
1258م)، رسالة الماجستير، كلية التربية_ جامعة الموصل، المبرد (الموصل، 1996).

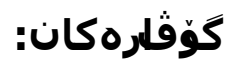

_ الهورمزياري: جتو حمدامين سمايل

ـ وسائل الصيد المعاصرة دراسة فقهية، مجلة جامعة كويه، العدد/22، (كويه، 2012).76 _ الويس: كامل طه

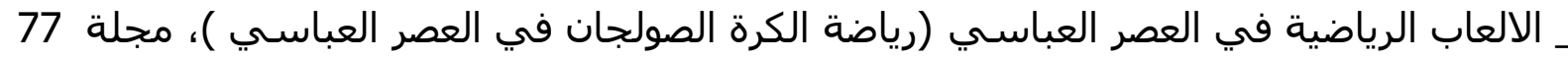
كلية التربية الرياضية، العدد/ 12، بغدادراد، 2003).

\section{References}

Abbasi (d: 710 AH / 1310AD). (1989). Effects of the first in the ranking of countries, investigation: Abdulrahman Hameera, Dar Jil, Beirut.

Abu al_Fida (d. 732 AH / 1321 AD). (1999). Abbreviations in the news of humans, investigation: Mohammed Zainham Arabs and Yahya Sayed Hussein, Dar Maarif, Cairo.

Abu Daoud (d. 204 AH / 819 AD). (1999). Musnad Abi Dawood al-Tilasi, investigation: Mohammed bin Abdul-Mohsen al-Turki, Dar Hajar. Egypt.

Abu Shama (d. 665 AH / 1266). (2002). The translations of the men of the sixth and seventh centuries known as the tail on the Roudhtiten, put his footnotes and commented on it: Ibrahim Shams al-Din, Dar al-Kuttab al-Alami, Beirut. 
Abu Shama (d. 665 AH / 1266). (1997). Al-Rawdatin in the News of the Two New States and the Authority, Ibrahim al-Zaybq, Al-Resala Foundation, Beirut.

AL_ Qafti (d. 646 AH / 1248 AD). (1982). Narrated by narrators on the objets of the grammarians, by: Mohammed Abu al- Fadl Ibrahim, Cultural Books Foundation, Beirut.

Al_thahaby (d. 748 AH / 1347 AD).(2003). History of Islam and the deaths of celebrities and media, investigation: Bashar Awwad Marouf, Dar al-Gharb al-Islami, Beirut.

AL_ yunini (d: 726 AH / 1326 AD). (1992). Tail of the mirror of time, the Islamic Book House, Cairo.

Albert. D.A. (1896). Historia Nicenae Vel Anticochenae prologum, Paris.

Al-Dumeir (d. 808 AH / 1406 AD). (2003). The Life of the Great Animal, Dar al-Kitab al'Ilami, Beirut.

Al_dwadawari (d. 736 AH / 1363 AD). (1972). Treasure of Aldar and Mosque of Gharar (Durr required in the news of Bani Ayoub), investigation: Said Abdel Fattah Ashour, House of Arabic books revival, Cairo.

Al-Hamdny (d. 695 AH / 1295 AD).(1984). Equestrian and military positions, investigation: Eid Deif al-Abadi, Ministry of Culture and Information, Baghdad.

Al-Jahiz (d: 255AH / 866 AD). (1914). Crown in the ethics of kings, investigation: Ahmed Zaki Pasha, Amiri Press, and Cairo.

Al-Jawaliki (d. 540 AH / 1145 AD). (1990). Al-Ma'arab from Al-Ajami on the letters of the dictionary, Dar Al-Qalam, Damascus.

Ibn Qayyim al-Jawziyya (d. 751 AH / 1351 AD).( 1993). Equestrian, investigation: Mashhur bin Hassan bin Mahmoud bin Salman, Dar al-Andalus, Saudi Arabia.

Al-Qalqashandi (d. 821 AH / 1418 AD). (1987). Sobh al-A'ashah in the Al-Ansha industry, investigation: Muhammad Hussein Shams al-Din, Dar al-Kuttab al-Alami Beirut.

Al-Qalqashandi (d. 821 AH / 1418 AD). (1985) .the exploits of Al-Anfa in the features of the Caliphate, by: Abdul Sattar Ahmed Faraj, Kuwait Government Press, and Kuwait.

Al-Sakhawi (d. 902 AH / 1497 AD). The leader of the protester in chess rule, a manuscript, published on www.alukah.net.

Alwais. K. T. (2003). Athletics in the Abbasid Period (Sports Bowl in the Abbasid Period), Journal of Physical Education College, No. 12, Baghdad. 
Anonymous author (died after 655 AH / 1257 AD). (2010). History of the State of the Kurds and Turks (History of the State of the Kurds), study and investigation: Musa Mustafa al-Hasaniani, publications of the University of Dohuk, Dohuk.

Anonymous author: (from the writings of the seventh century AH). (2007). the Seljuks of Rum (Saljuknama), Translated by: Mohammed Al-Said Jamal Aldin, the National Project of Translation, Cairo.

Atrushi. Sh. A. (2007). Intellectual Life in Egypt during the Ayyubid Age. Amman.

Badawi. A. A. (1953). Mamoun Bani Ayoub al-Ma'izam Issa, Printing Press Committee of the Arab statement, Cairo.

Badawi. A. A. (2000). Kingdom of Homs in the Ayyubid era, presented by: Suhail Zoukar, Dar Tlas, Damascus.

Hanbali (d. 876 AH / 1471). (1978). healing the hearts in Mneqib Bani Ayoub, investigation: Nazim Rashid, Freedom House for printing, Baghdad.

Hayek. M. (2000). Kingdom of Homs in the Ayyubid era, presented by: Suhail Zoukar, Dar Tlas, Damascus.

Horemzari. G. S. (2012). Contemporary hunting Tools Juristic Study, Journal of the University of Koya, No. 22, Koya.

Ibn Abi Yashat (d. 668 AH / 1269 AD). (D.T). News of the news in the layers of doctors, Tqebq: Nizar Reza, Library of Life, and Beirut.

Ibn al-Abri (d: 685 AH / 1286 AD). (1992). Brief History of States, investigation: Antoine Salhani Jesuit, Dar al-Sharq, Beirut.

Ibn al-'Adim (d.660 AH / 1261 AD). (1988). With a view to the demand in the history of Aleppo, Suhail Zoukar, Dar al-Fikr, Beirut.

Ibn al-Atheer (d. 630 AH / 1232 AD). (1997). full in history, investigation: Omar Abdel Salam al-Tadmari, Dar al-Kitab al-Arabi, Beirut.

Ibn al-Fouti (d: 723 AH / 1323 AD). (1962). Summary of the complex of literature in the dictionary of titles, the investigation: Mustafa Jawad, the Directorate of the Department of Old Heritage, Damascus.

Ibn al-Mu'taz (d: 296 AH / 908 AD). (DT). Layers of poets, investigation: Abdel-Sattar Ahmed Farrag, Dar Maarif, Cairo.

Ibn al-Sha'ar (d. 654 AH / 1256 AD). (2005). Qallayd Juman in the poets of this time famous decades of Juman in the poets of this time, the investigation: Kamel Salman Jubouri, Dar al-Kuttab al-Ulami, Beirut. 
Ibn Fadlullah al-Amri (d. 749 AH / 1378 AD). (2002). Pathways of sight in the kingdoms of Amazar, Cultural Complex, Abu Dhabi.

Ibn Kathir (d. 774 AH / 1373AD). (1988). the Beginning and the End, Ali Shiri, Arab Revival and Heritage, Beirut.

Ibn Kathir (d. 774 AH / 1373AD). (1993). Tafsat El-Shafoui, Investigation: Ahmed Omar Hashim and Mohamed Zainham Mohamed Azab, Library of Religious Culture, MD.

Ibn Khalkan(d. 681 AH / 1282AD). (1994). Deaths of the elderly and the sons of time, the investigation: Ihsan Abbas, 1-3, 1990, C 41971 Dar Sader, Beirut.

Ibn Munqadh(d. 584 AH / 1188 AD). (DT). Mind, edited by: Flip Up, The Library of Religious Culture, Egypt.

Ibn Nazif al-Hamawi (d. 644 AH / 1246 AD). (1981). Al-Mansoori History (Summarizing the Reveal and Statement in Time Incidents), by: Abu Eid Doudou, Review: Adnan Darwish, the Arabic Language Complex, and Damascus.

Ibn Qayyim al-Jawziyya (d. 751 AH / 1351 AD). (1993). equestrian, investigation: Mashhur bin Hassan bin Mahmoud bin Salman, Dar al-Andalus, Saudi Arabia.

Ibn Qutaiba al-Dinuri (d. 276 AH / 889 AD). (1997). Oyoun al-Akhbar, Dar al-Kitab alSallami, Beirut.

Ibn qzl al_ mushed (d: 656 AH / 1258 AD). (2002). Diwan of Ibn Qazal Almashd, investigation: famous Abdul Rahman Habazi, Jerusalem.

Ibn Shaddad (d. 632 AH / 1234 AD). (2005). The Royal Juices and the Prospects of Yusufiyah or the biography of Sultan Al-Nasir Salah Al-Din Al-Ayoubi, investigation: Ahmed Ibash, Damascus.

Ibn Shaddad (d: 684 AH / 1285 AD). (1987). Dangerous relations in the mention of the princes of the Levant and the island, investigation: Yahya Zakaria phrase, publications of the Ministry of Culture and National Guidance, Damshef.

Ibn Tghri Bardi ((d. 874 AH / 1469 AD). (D.T). Stars shining in the kings of Egypt and Cairo, the Ministry of Culture and National Guidance, Egypt.

Ibn Tulun(d. 953 AH / 1546AD). (1992). Criticism of the student to occupy positions, investigation: Mohammed Ahmed Dahman and Khalid Mohammed Dahman reviewed by: Nizar Abaza, Contemporary Thought House, Beirut.

Ibn Wasel (d: 697 AH / 1297 AD). (2010). History Salhi, investigation: Omar Abdulsalam Tadmari, Modern Library, Beirut. 
Ibn Wasel (d: 697 AH / 1297 AD). (1957). Mufruj al-Karub in the news of Bani Ayoub, J1_5, and investigation: Gamal al-Din Shayal, Amiriya Press, Cairo.

Ibn Wasel (d: 697 AH / 1297 AD). (2004). Mufrouj al-Kroub in the news of Bani Ayoub, J6, and investigation: Omar Abdulsalam al-Tadmari, the modern library, Beirut.

Ibrahim. Kh. S. (2013). Social life in Egypt in the Ayyubid era (567-648 / 1171-1250), Dar alBasayr for printing and publishing, Beirut.

Khatib. M. K. (1996). Glossary of Terms and Historical Words, Beirut.

King Al-Nasir Dawood ((d. 656 AH / 1258 AD). (1992). The obvious benefits in the Nasiriyah literature (letters and poetry), by: Nazem Rashid, House of Public Cultural Affairs. Baghdad.

Kutbi (d. 764 AH / 1363 AD). (1974). Fatalities, Achievement: Ihsan Abbas, Dar Sader, Beirut.

Maqrizi (d. 845 AH / 1441AD). (1997). Behavior to teach the kings, the investigation: Mohammed Abdul Qadir Atta, Dar al-Kuttab al-Alami, Beirut.

Masoudi (d: 346 AH / 957 AD). (2005). Gold promoters and mineral minerals, investigation: Mohammed Hisham Al-Nusan and Abdulmajid Tameh Halabi, Dar Al-Maarifah, Beirut.

Muderes. K. M. (1983). Our scientists in the service of science and religion, published by: Muhammad Ali al-Qardaghi, Baghdad.

Murray.H.X.R (1913). History of chess, Oxford.

Muslim bin Hajjaj (d. 261 AH / 874 AD). (D.T). Saheeh Muslim, Inquiry: Mohamed Fouad Abdel-Baki, House of Revival of Arab Heritage, Beirut.

Mustafa. Sh. (1988). Cities in Islam until the Ottoman era, Dar Al-Salsal for Printing and Publishing, Kuwait.

Nassar. L. A. (1999). The means of entertainment in the era of the Mamluk sultans in Egypt, the Egyptian General Book Press, Egypt.

Nuri. N. M. (1996). Festivities, events and entertainment in Baghdad during the Abbasid period (145-656 / 763-1258), Master's thesis, Faculty of Education _ Mosul University, Mosul.

Nuwairi (d. 733 AH / 1322 AD). (2004). End of Arb in the arts of literature, investigation: Naguib Mustafa Fawaz and Hikmat Kashli Fawaz, House of Scientific Books, Beirut.

Pasha. O. M. (1989). Literature in the Levant of the era of the Znokis and the Ayyubids and Mamluks, Dar al-Fikr, Damascus. 
Qazwini (d: 682 AH / 1283 AD). (D.T). the effects of the country and Khobar Abad, Dar Sader, Beirut.

Rajab. . G. I. (2003). Civilizations in the fourth century AH Study in the light of the gold promoter Masoudi, Cairo.

Sabki (d: 771 AH / 1369 AD). (1992). layers of the great Shafei, investigation: Mahmoud Mohammed Al-Tanahi and Abdel-Fattah Mohamed El-Helou, Cairo.

Safadi (d: 764 AH / 1363AD). (2000). Al-Wafi Al-Fatifiyat, investigation: Ahmad AlArnaout and Turki Mustafa, Dar Al-Tariyat Al-Tarath, Beirut.

Samarrai. F. S. (2004). Damascene Traditions and Traditions during the Seljuk-ChalukinAyyubid Periods, Dar Al-Awael Publishing and Distribution, Damascus.

Sayegh. H. Z. (1980). Trends of Arabic poetry in the seventh century AH in the Levant, PhD thesis, Faculty of Arts - Cairo University, Cairo.

Shalaby. A. (1986). Social Life in Islamic Thought, the Egyptian Renaissance Library, I5 ,Cairo.

Sharaf al-Din al-Ansari (d. 662 AH / 1223 AD). (D.T). Diwan Al-Saheb Sharaf Al-Din AlAnsari, Inquiry: Omar Musa Pasha, Arabic Language Complex, Damascus.

Shmeisani. H. (1983). The city of Sinjar from the Arab Islamic conquest until the Ottoman conquest, New Horizons House, Beirut.

Sophaje. J. (1936). Damascus Sham, Beirut.

Subet Ibn al-Jawzi (d. 654 AH / 1256 AD). (1951). the History of Time in the History of the Elders, the Ottoman Knowledge Department Press, Hyderabad.

Yaqoot al-Hamawi (d. 626 AH / 1229 AD). (1995). Dar Al-Sadir, Dar al-Sadir, Beirut. 